UNIVERSIDADE DE SÃO PAULO

INSTITUTO DE GEOCIÊNCIAS

\title{
CORRELAÇÃO DE DADOS GEOLÓGICOS E GEOTÉCNICOS NA BACIA DE SÃO PAULO
}

\author{
MAGALI DUBAS GURGUEIRA \\ Orientador: Prof. Dr. Claudio Riccomini
}

DISSERTAÇÃO DE MESTRADO

Programa de Pós-Graduação em Geoquímica e Geotectônica

São Paulo, 2013 


\section{AGRADECIMENTOS}

Agradeço a Companhia do Metropolitano de São Paulo - Metrô e ao Consórcio Monotrilho Integração pelo fornecimento dos dados utilizados neste trabalho. Ao Prof. Dr. Claudio Riccomini pela orientação e luz nas muitas dúvidas que surgiram no caminho.

Aos colegas e profissionais que colaboraram com trocas de ideias e apoio no desenvolvimento deste trabalho: Geól. Marcelo Denser, Geól. Fabrícia Massoni, Geól. Daniela Garroux e Geól. Hugo Cassio Rocha do Metrô-SP; Eng. Rogério Martinati, Geol. Luiz Fernando Dagostino, Eng. Murilo Martins, Eng. Suzane Yamamoto, Geól. Andrezza Mota, Geól. Mariana Silvatti, Geól. Bia Rago, Messias Gomes, Raimundo de Almeida e Mariana Fagundes da Núcleo de Projetos e Consultoria.

Aos mestres e colegas que colaboraram com minha formação profissional registro aqui minha admiração: Geól. Luiz Ferreira Vaz, Geól. Ana Elisa Abreu, Eng. Tarcisio Celestino, Eng. Carlos Takashi, Geol. Marilda Tressoldi, Geol. Talita Muzzi, Geol. Silvia Truffi, Geol. Daniel Buzzatto e Eng. Carolina Silvatti da Themag Engenharia. Ao Geól. Mirandola que possibilitou minha visita às escavações da Linha 5 do Metrô.

As empresas que executaram as sondagens utilizadas neste estudo: Núcleo de Projetos e Consultoria, Prospec, Fundsolo, Lenc e Contemat.

À minha família, meus pais, irmã e noivo pela paciência e apoio incondicional. Aos amigos pelo apoio e compreensão no período de ausência durante a produção deste documento. 


\section{PALAVRAS-CHAVE}

Bacia de São Paulo; Dados geológico-geotécnicos; Dados de sondagens; Linha 17-Ouro; Metrô de São Paulo;

\section{RESUMO}

A Bacia de São Paulo abriga a maior parte da principal região metropolitana do Brasil. Esta região concentra uma grande quantidade de obras subterrâneas, principalmente para fins de transporte público, executada nas rochas sedimentares que constituem a bacia.

A Bacia de São Paulo é caracterizada pela heterogeneidade litológica, herança da tectônica do tipo rift que condicionou a sedimentação de depósitos de leques aluviais associados à planície aluvial e sedimentos lacustres. Essa heterogeneidade traz importantes implicações no planejamento e execução de obras subterrâneas, mas sua caracterização vem sendo progressivamente dificultada com o avanço da ocupação urbana, o que limita o acesso às exposições de rochas. Por outro lado, em consequência do grande número de obras, encontra-se disponível um volume considerável de dados geotécnicos, cuja interpretação à luz dos conhecimentos geológicos é hoje a principal forma de se avançar no conhecimento geológicogeotécnico da bacia.

Neste trabalho buscou-se correlacionar dados geológicos e geotécnicos na Bacia de São Paulo. Para tanto foram empregados dados de sondagens e ensaios provenientes da Linha 17 - Ouro do Metrô de São Paulo, situada ao longo das avenidas Jornalista Roberto Marinho, Washington Luís e das Nações Unidas. Estes dados encontram-se disponíveis no acervo da Companhia do Metropolitano de São Paulo - Metrô. 
Foram realizadas análises tátil-visual das amostras para determinação das características e composição do material. Essas análises permitiram a definição de unidades geológico-geotécnicas, determinar a sua distribuição a partir de seções geológico-geotécnicas e as consequentes implicações para obras subterrâneas e de fundações.

As seções geológico-geotécnicas confeccionadas mostraram que a Formação São Paulo predomina acima da cota $740 m$ ao longo da Av. Washington Luís, a Formação Resende ocorre nas Avenidas Jornalista Roberto Marinho e Washington Luís e as rochas do embasamento predominam na região próxima à Marginal Pinheiros. Foram também identificadas falhas normais configurando um horst na Av. Jornalista Roberto Marinho. 


\section{TITLE}

Correlation of geological and geotechnical data in the São Paulo Basin

\section{KEYWORDS}

São Paulo Basin; Geological and geotechnical data; Core data; Line 17-Ouro; São Paulo subway;

\section{ABSTRACT}

The São Paulo Basin nestles most of the main metropolitan region of Brazil. Most of the underground works for public transport in the São Paulo city were performed in rocks of this basin.

The basin presents a lithologic and structural heterogeneity, an inheritance of the rifting processes responsible for its development that conditioned the deposition of sediments in alluvial fans, floodplains and lakes. Understanding these heterogeneities is essential for better planning and execution of undergound works, but the study of the basin is becoming increasingly difficult as a consequence of urban occupation. The large number of undergound works, however, make available a considerable amount of geotechnical data, whose interpretation is the main way to advance in the knowledge of the geological and geotechnical characteristics of the São Paulo Basin.

This study aimed to correlate geological and geotechnical data in the São Paulo Basin. We employed data from cores obtained along the Line 17 - Ouro, of the São Paulo Metro, located along the avenues Jornalista Roberto Marinho, Washington Luís and Nações Unidas. These data are available in the collection of the Metropolitan Company of São Paulo - Metro. 
Samples from cores were submitted to visual-tactile analysis in order to determine their characteristics and composition. The analysis allowed the definition of gelogical and geotechnical units, their distributions and implications for underground works and foundations.

The geological and geotechnical sections showed that the São Paulo Formation predominates above 740m along the Washington Luís Avenue, the Resende Formation occurs in the avenues Jornalista Roberto Marinho and Washington Luís and the basement rocks predominate in the region near the Marginal Pinheiros. We also identified normal faults configuring a horst in the Jornalista Roberto Marinho Avenue. 


\section{ÍNDICE}

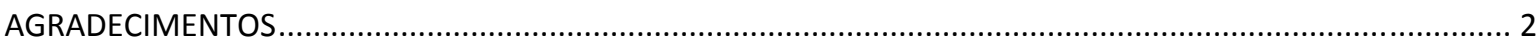

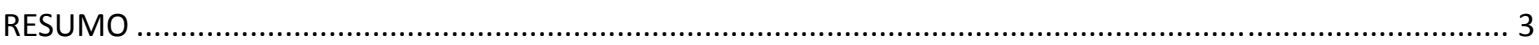

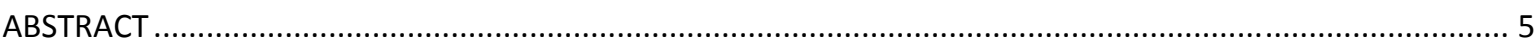

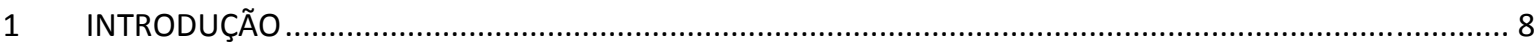

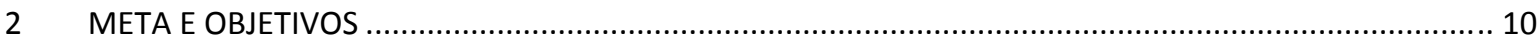

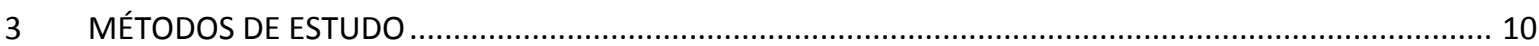

4 A BACIA DE SÃO PAULO NO CONTEXTO DO RIFT CONTINENTAL DO SUDESTE DO BRASIL ................... 11

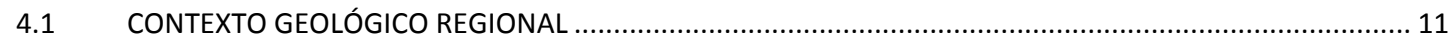

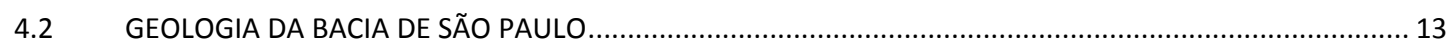

4.2.1 EVOLUÇÃO DO CONHECIMENTO GEOLÓGICO SOBRE A BACIA DE SÃO PAULO................................... 13

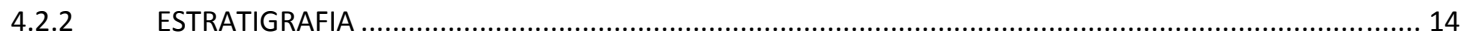

G.2.3 GEOLOGIA ESTRUTURAL E TECTÔNICA ….................................................................................. 31

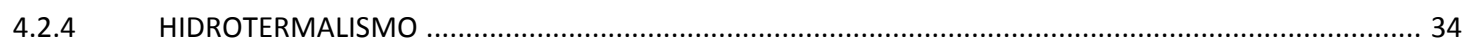

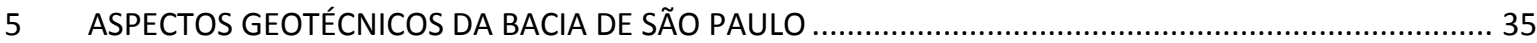

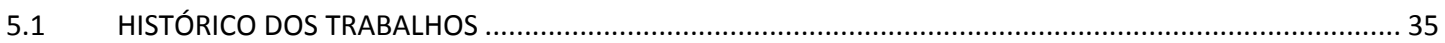

5.2 AS INFORMAÇÕES ADVINDAS DAS OBRAS METROVIÁRIAS NA BACIA DE SÃO PAULO............................ 37

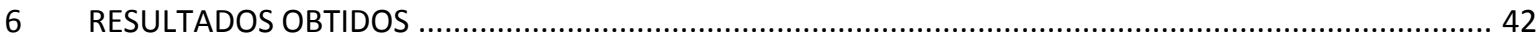

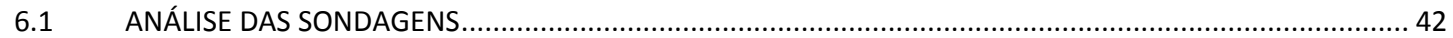

6.2 DEFINIÇÃO DAS UNIDADES GEOLÓGICO-GEOTÉCNICAS............................................................... 46

6.3 CORRELAÇÃO DOS PERFIS DE SONDAGENS E ELABORAÇÃO DE SEÇÕES GEOLÓGICO-GEOTÉCNICAS.......51

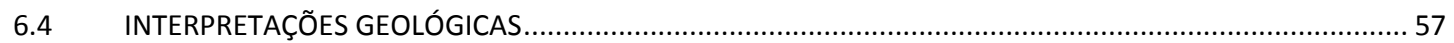

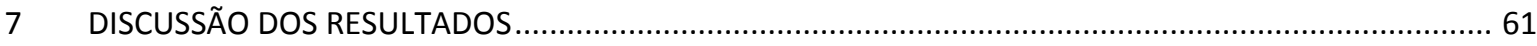

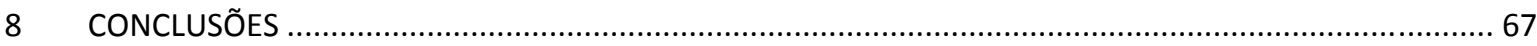

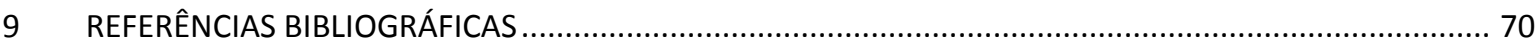




\section{INTRODUÇÃO}

A Bacia de São Paulo localiza-se no Planalto Atlântico, na porção leste do Estado de São Paulo. Com área pouco superior a $1.000 \mathrm{~km}^{2}$, apresenta rochas sedimentares distribuídas irregularmente numa faixa com eixo maior de $75 \mathrm{~km}$, entre Arujá, a leste, e Embu-Guaçu, a oeste, e menor de $25 \mathrm{~km}$, entre Santana, ao norte, e Santo André, ao sul (Riccomini \& Coimbra, 1992; Riccomini et al., 2004) e espessura máxima contínua verificada em sondagens de 290m (Takiya, 1991).

A Bacia de São Paulo faz parte de um conjunto de bacias pertencentes ao Rift Continental do Sudeste do Brasil - RCSB (Riccomini, 1989). Com idade terciária, esta bacia assenta-se sobre rochas ígneas e metamórficas do Cinturão de Dobramentos Ribeira e sua formação está relacionada à tectônica distensiva.

O preenchimento sedimentar é caracterizado pela presença de leques aluviais, planície aluvial e lacustre, de idade paleogênica, e por depósitos fluviais meandrantes, aluviais e coluviais, do Neógeno até o Quaternário (Riccomini, 1989).

Situada no maior centro urbano do país, São Paulo, esta bacia apresenta grande número de obras subterrâneas já concluídas, em fase de construção ou planejamento, principalmente túneis viários ou metroviários destinados ao transporte público.

Acredita-se que as obras subterrâneas na Bacia de São Paulo tiveram início no ano de 1925, com a execução de túneis para adutoras (Silva-Teles, 2006). O primeiro túnel rodoviário construído na cidade de São Paulo, túnel Daher Elias Cutait (antigo Nove de Julho), teve início em 1936, coincidente com o período de início do reconhecimento de subsolo pelo Instituto de Pesquisas Tecnológicas (IPT). Este túnel foi construído com o objetivo de escoar o crescente tráfego de ônibus e veículos particulares que disputavam espaço com o intenso fluxo de bondes. Foram utilizadas duas técnicas construtivas: a mineira e o método de túnel invertido (Carvalho, 2006). 
Dentre os túneis rodoviários na Bacia de São Paulo, destacam-se as obras realizadas com a técnica construtiva NATM (New Austrian Tunnelling Method), sendo eles: Túnel Maria Maluf (início em 1987, com 1.476m de extensão, em rochas sedimentares da Fm. São Paulo), Túnel Jânio Quadros e Sebastião Camargo (início em 1987, com 1.151m, em rochas sedimentares da Fm. Resende), Túnel Ayrton Senna (início em 1988, com 2.138m, em rochas sedimentares da Fm. Resende), Túnel Tribunal de Justiça (início em 1988, com 683m, em rochas sedimentares da Fm. Resende) e Túnel Cidade Jardim (início em 2004, com 1.181m, interceptando contatos de aluvião com rochas sedimentares da $\mathrm{Fm}$. Resende e solos residuais do embasamento).

A execução de túneis metroferroviários teve início em 1969, com as obras no trecho sul da linha 1 (azul) do Metrô de São Paulo (Rocha, 2006), com o emprego do método em trincheira (VCA). O Metrô de São Paulo foi pioneiro na construção de túneis em tuneladoras com couraça (shield), tendo utilizado quatro máquinas tuneladoras para a construção do trecho central da linha 1, após a definição das condições geológicas e o greide da linha.

Os túneis do trecho central da linha 3 (vermelha) também foram executadas utilizando-se máquinas tuneladoras. As obras da linha 2 (verde) utilizaram dois tipos diferentes de tuneladoras. A primeira utilização do método NATM em obras metroferroviárias ocorreu no projeto de extensão da linha 1. Na recente construção da linha 4 (amarela) utilizou-se dois métodos distintos: NATM (trecho do embasamento) e Shield (trecho de rochas sedimentares da Bacia de São Paulo) com utilização de tuneladora de última geração.

A execução de novas obras subterrâneas na Bacia de São Paulo está assegurada tendo em vista o aumento na demanda de obras rodoviárias e metroferroviárias para mobilidade urbana, além da continuidade da execução de adutoras e obras de drenagem. 
As perspectivas de projeto das novas obras incluem a redução nos prazos de conclusão e previsibilidade das condições adversas para sua execução. Com a evolução dos métodos construtivos, torna-se cada vez mais fundamental a definição das condições geológico-geotécnicas e características geomecânicas dos materiais na fase de projeto, pois o sucesso da aplicação do método construtivo escolhido está diretamente ligado a previsão eficiente das características dos materiais.

\section{META E OBJETIVOS}

O presente estudo pretende contribuir com dados atualizados acerca das características geológicas e geotécnicas dos materiais que constituem o substrato de São Paulo, com dados provenientes de parte das obras metroviárias em andamento, principalmente da Linha 17 - Ouro no trecho entre a Avenida Washington Luís, Avenida Jornalista Roberto Marinho e Avenida das Nações Unidas (Marginal Pinheiros).

São discutidas as unidades geológicas presentes na bacia e algumas metodologias de classificação geológico-geotécnicas utilizadas nos atuais projetos de engenharia, com a apresentação de uma classificação sugerida neste estudo e a interpretação geológica realizada mediante a análise de sondagens rotativas e a percussão, correlacionando os dados geológicos e geotécnicos.

\section{MÉTODOS DE ESTUDO}

A elaboração dos projetos referentes as obras metroferroviárias confere a disponibilidade de um grande número de sondagens arquivadas junto à Companhia do Metropolitano de São Paulo - CMSP (Metrô). Estas sondagens foram executadas visando o conhecimento geológico-geotécnico dos materiais escavados (no caso dos túneis e estações) ou que constituem as fundações (no caso de obras aéreas e sistemas monotrilho).

Este estudo foi desenvolvido mediante a consulta de parte das sondagens do acervo do Metrô, devidamente autorizada em carta desde o dia 29 de setembro de 
2010 para os fins requeridos, e de visitas às escavações de parte das obras metroviárias em andamento.

As sondagens a percussão e rotativas foram executadas com o objetivo de investigar e projetar as fundações da Linha 17 - Ouro do Metrô de São Paulo, de acordo com a NBR-6484/2010 e com o manual de sondagens da ABGE (Associação Brasileira de Geologia de Engenharia, 1999). As sondagens foram analisadas, realizando-se a classificação tátil-visual das amostras, identificação das unidades geológico correspondentes, resultados dos ensaios de SPT (para aterros, aluviões, rochas sedimentares da Bacia de São Paulo e solos de alteração das rochas do embasamento) e de Resistência à Compressão Uniaxial (para as rochas do embasamento e rochas sedimentares cimentadas da Bacia de São Paulo).

Após estas análises foram lançadas todas as sondagens em planta e traçadas seções geológicas com a interpretação dos contatos e correlações entre as diferentes unidades geológicas, além da identificação das estruturas geológicas quando possível.

Por fim, foram identificadas e avaliadas as características geológicas e geotécnicas dos materiais, comparando-se com as informações disponíveis na literatura.

\section{A BACIA DE SÃO PAULO NO CONTEXTO DO RIFT CONTINENTAL DO SUDESTE DO BRASIL}

A Bacia de São Paulo tem seu desenvolvimento relacionado à tectônica distensiva de idade terciária e faz parte de um conjunto de bacias pertencentes ao Rift Continental do Sudeste do Brasil (Riccomini, 1989).

\subsection{CONTEXTO GEOLÓGICO REGIONAL}

O Rift Continental do Sudeste do Brasil (RCSB) é uma feição tectônica de idade cenozoica. Desenvolveu-se sobre gnaisses, migmatitos e rochas metamórficas de baixo 
a médio grau, de idade arqueana a neoproterozoica, do Cinturão Ribeira (Almeida et al., 1973), ou Cinturão de Dobramentos Ribeira (Hasui et al.,1975), e diversas suítes de rochas granitóides intrusivas, de idade neoproterozoica (Janasi \& Ulbrich, 1991), que compõem o embasamento cristalino regional (Figura 1).

Hasui et al. (1978) e Schobbenhaus et al. (1984) referiram-se a esta área como Região de Dobramentos Sudeste, devido a sua posição na Plataforma Sul-Americana (Almeida et al., 1976), e Almeida \& Hasui (1984) incluiram-na no setor central da Província Mantiqueira. Característica notável deste cinturão é o seu recorte por densa trama de zonas de cisalhamento dúcteis, orientadas segundo ENE a E-W (Sadowski \& Motidome, 1987), ativas até o final do Ciclo Brasiliano, no Cambro-Ordoviciano. São zonas de cisalhamento dextrais subverticais e profundas, que registram importante componente transpressional durante a evolução do cinturão (Trouw et al., 2000).

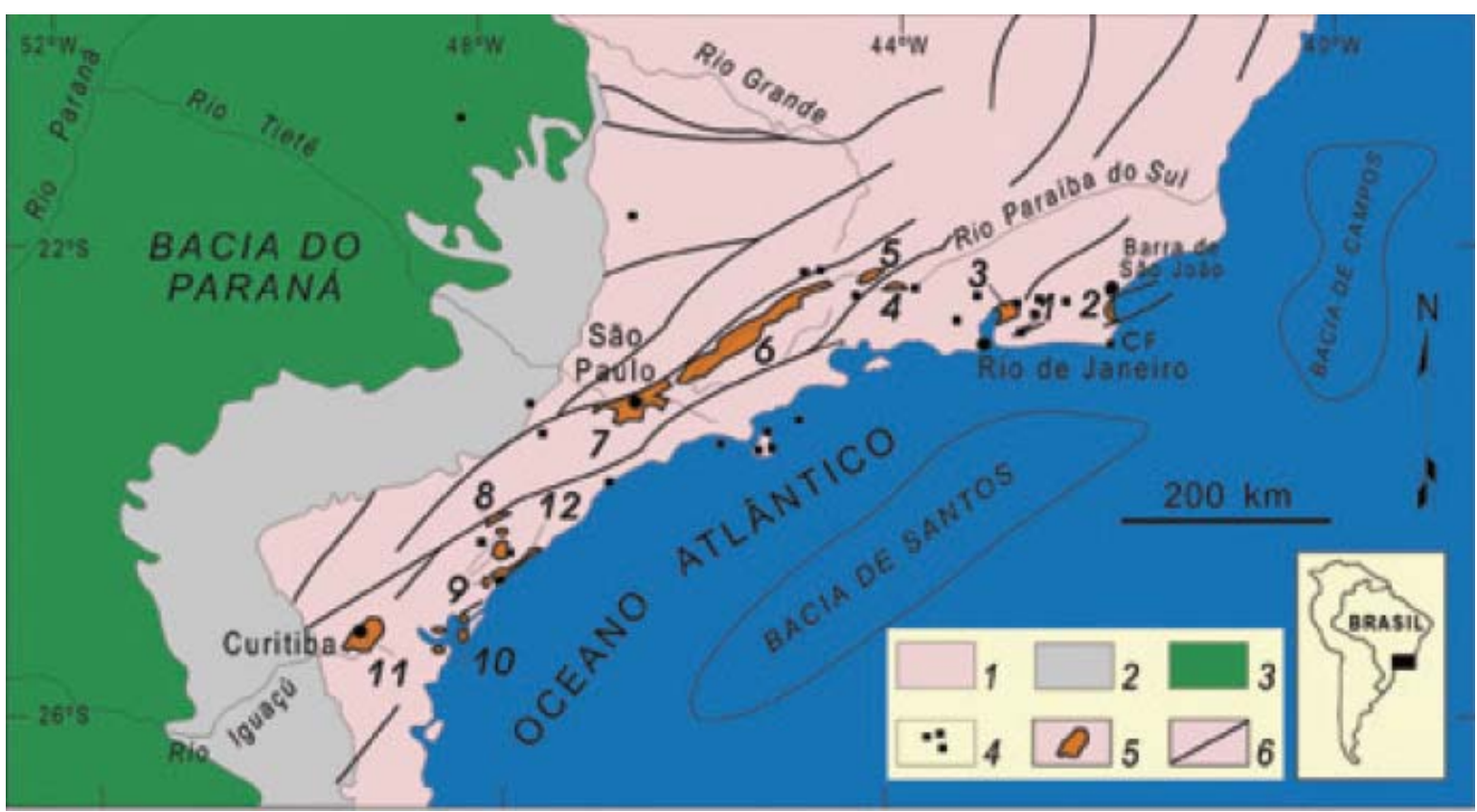

Figura 1 - Contexto geológico regional do RCSB - 1) embasamento pré-cambriano; 2) rochas sedimentares paleozoicas da Bacia do Paraná; 3) rochas vulcânicas toleíticas eocretáceas da Formação Serra Geral; 4) rochas relacionadas ao magmatismo alcalino mesozoico-cenozoico; 5) bacias cenozoicas do rift (1- Bacia de Itaboraí, 2Gráben de Barra de São João, 3- Bacia do Macacu, 4- Bacia de Volta Redonda, 5- Bacia de Resende, 6- Bacia de Taubaté, 7- Bacia de São Paulo, 8- Gráben de Sete Barras, 9- Formação Pariqüera-Açu, 10- Formação Alexandra e Gráben de Guaraqueçaba, 11- Bacia de Curitiba, 12- Gráben de Cananéia); 6) zonas de cisalhamento précambrianas, em parte reativadas durante o Mesozoico e Cenozoico. Fonte: Riccomini et al. (2004). 
A partir do Jurássico Superior a região esteve sujeita aos fenômenos relacionados inicialmente à Reativação Wealdeniana (Almeida, 1967), que evoluíram sucessivamente para a ruptura continental e abertura do Atlântico. Este processo tem início marcado pelo vulcanismo basáltico eocretáceo da Formação Serra Geral. Inclui ainda manifestações alcalinas, distribuídas em três pulsos principais: Eocretáceo; Neocretáceo a Paleoceno; Eoceno.

Segundo Riccomini et al. (2004) admite-se hoje, de forma consensual, a existência de vínculo entre a instalação e desenvolvimento do RCSB com o Evento SulAtlantiano. Embora os diferentes modelos propostos para a origem dessas bacias tafrogênicas apresentem convergência ao relacioná-las com o tectonismo e a morfogênese que levaram à formação das serras do Mar e da Mantiqueira, não há consenso quanto aos seus mecanismos geradores. Por outro lado, são ainda pouco numerosos os estudos dedicados ao tectonismo deformador ou modificador dessas bacias, incluindo importante atividade neotectônica.

\subsection{GEOLOGIA DA BACIA DE SÃO PAULO}

\subsubsection{EVOLUÇÃO DO CONHECIMENTO GEOLÓGICO SOBRE A BACIA DE SÃO PAULO}

As rochas sedimentares da Bacia de São Paulo foram inicialmente referidas por Mawe (1812). Outros estudos se sucederam até que Moraes Rego (1933) introduzisse a denominação "Camadas de São Paulo", sendo que a "Formação São Paulo" foi apresentada inicialmente por Mezzalira (1962). Porém somente a partir da década de 1980 mais estudos passaram a ser produzidos sobre a geologia da Bacia de São Paulo.

Nesta década, dois encontros foram promovidos sobre o tema, o primeiro organizado pela ABGE/SBG em 1980 e o segundo pelo IGUSP/SBG em 1989. A Formação Itaquaquecetuba foi definida no estudo de Coimbra et al. (1983) em substituição aos "aluviões antigos dos rios Pinheiros e Tietê" de Suguio \& Takahashi 
(1970), formação também estudada no trabalho de Melo et al. (1989). O mapa geológico da região metropolitana de São Paulo foi publicado por Coutinho (1980a).

O trabalho de Riccomini (1989) reformulou a litoestratigrafia da Bacia de São Paulo, incluindo-a no contexto do Rift Continental do Sudeste do Brasil, sendo constituída pelas formações Resende, Tremembé, São Paulo e Itaquaquecetuba. Esta sistematização permanece atualizada, sendo utilizada nos estudos desde então.

O arcabouço da Bacia de São Paulo pode ser delineado graças ao grande volume de dados de poços para água subterrânea, conforme os estudos de Hasui \& Carneiro (1980) e Takiya (1991). Os trabalhos que utilizaram dados provenientes das obras subterrâneas, como de Cozzolino (1980), Cozzolino et al. (1994) e Rocha (1995), contribuíram com informações quanto a litologia e estruturas na bacia.

Por fim, o trabalho de Riccomini et al. (2004) apresentou uma síntese e atualização dos conhecimentos na bacia, aspectos também discutidos no seminário "Twin Cities - Solos das regiões metropolitanas de São Paulo e Curitiba", organizado pela ABMS em 2012.

\subsubsection{ESTRATIGRAFIA}

A geologia da Região Metropolitana de São Paulo (RMSP) é representada por três grandes compartimentos sendo, em ordem estratigráfica, o embasamento précambriano, as rochas sedimentares paleógenas a neógenas da Bacia de São Paulo e as coberturas quaternárias, detalhados a seguir.

\subsubsection{Embasamento pré-cambriano}

O embasamento da Bacia de São Paulo está inserido em um complexo sistema influenciado por várias entidades geotectônicas (Monteiro et al., 2012). Hasui (2010) menciona que, embora a história geológica regional remonte ao Arqueano (4000 a $2500 \mathrm{Ma})$ e envolva processos paleoproterozoicos (2500 a $1600 \mathrm{Ma})$ e 
mesoproterozoicos (1600 a $1000 \mathrm{Ma})$ relacionados com a evolução dos supercontinentes Colúmbia e Rodínia, é no Neoproterozoico (1000 a 542 Ma) que incidiram os movimentos de fragmentação e colisão a que se deve a estruturação regional aqui encontrada.

Os traços estruturais nestes processos colisionais representam uma importante herança que controlou boa parte dos processos geotectônicos posteriores, como a implantação da Bacia do Paraná e a Reativação Sul-Atlantiana a que se relaciona ativo magmatismo, rifteamento, morfogênese e a abertura do Atlântico (processo também relacionado à formação das bacias de São Paulo, Taubaté e outras).

O embasamento da Bacia de São Paulo faz parte do Sistema Orogênico Mantiqueira, que corresponde à Província Mantiqueira (Almeida et al., 1977), unidade decorrente da orogenia neoproterozoica, Brasiliano - Panafricana, que resultou na formação do paleocontinente Gondwana Ocidental. Dentro deste contexto, o orógeno Ribeira é a unidade geotectônica que efetivamente abriga a Bacia de São Paulo e o seu embasamento, onde, segundo Juliani (1992), ocorrem majoritariamente duas unidades geológicas separadas pelas falhas de Taxaquara e do Rio Jaguari, além das rochas granitóides intrusivas. A estruturação regional NNE-SSW (Figura 2) é condicionada por um sistema de falhas transcorrentes denominado Sistema Transcorrente Paraíba do Sul (Hasui et al. 1975). 


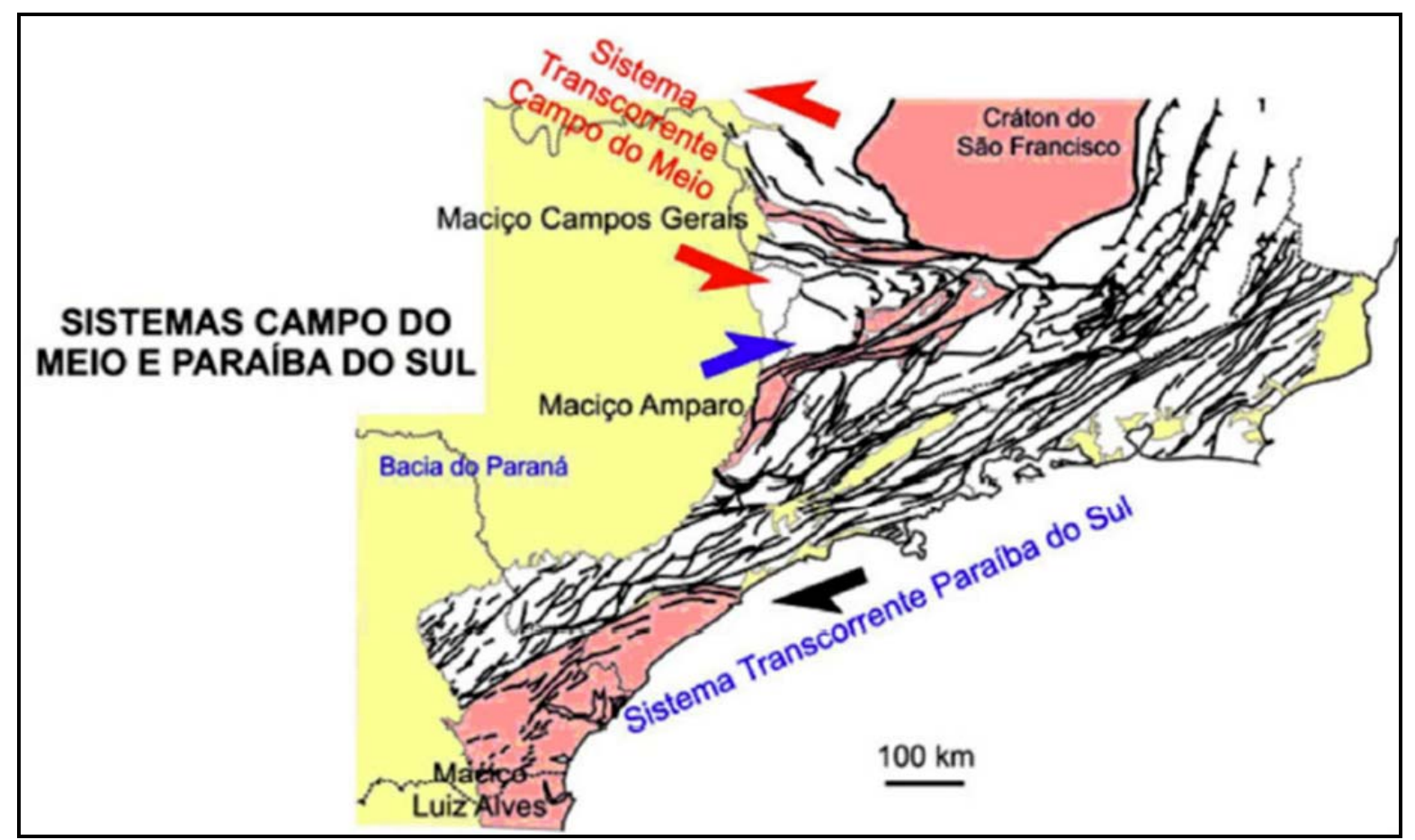

Figura 2 - Os sistemas transcorrentes Campo do Meio e Paraíba do Sul. Notar a orientação preferencial NE-SW dos alinhamentos no Sistema Paraíba do Sul, onde está inserido o embasamento da Bacia de São Paulo. Fonte: Monteiro et al. (2012).

As falhas de Taxaquara e de Caucaia, que fazem parte do sistema de falhas transcorrentes supracitado, são responsáveis por feições importantes do embasamento. Na altura do Rio Tietê ocorre a Falha de Taxaquara, a norte da qual estão as rochas dos grupos São Roque e Serra do Itaberaba (Terrenos Apiaí-São Roque, conforme Heilbron et al., 2004), intrudidos por corpos graníticos. Ao sul da Falha Caucaia ocorrem terrenos distintos associados ao orógeno Ribeira; estes são o Complexo Embu e, mais a sul, o Complexo Costeiro, ambos intrudidos por vários corpos graníticos neoproterozoicos (Terreno Embu, conforme Heilbron et al., 2004).

A Bacia de São Paulo apresenta, ao sul, contato irregular com seu embasamento; a leste e oeste, os limites são condicionados por elevações do embasamento (Cozzolino, 1996). As falhas do Taxaquara e Rio Jaguari delimitam a norte a Bacia de São Paulo.

O embasamento da Bacia de São Paulo é basicamente constituído por rochas metamórficas e ígneas, associadas ao Complexo Embu e aos grupos São Roque e Serra do Itaberaba, além de corpos de rochas granitóides intrusivas (Monteiro et al., 2012). 
Com menor expressão ocorrem as rochas do Complexo Costeiro, Complexo Pico do Papagaio, da Nappe Socorro-Guaxupé e do Grupo Votuverava (Figura 3).

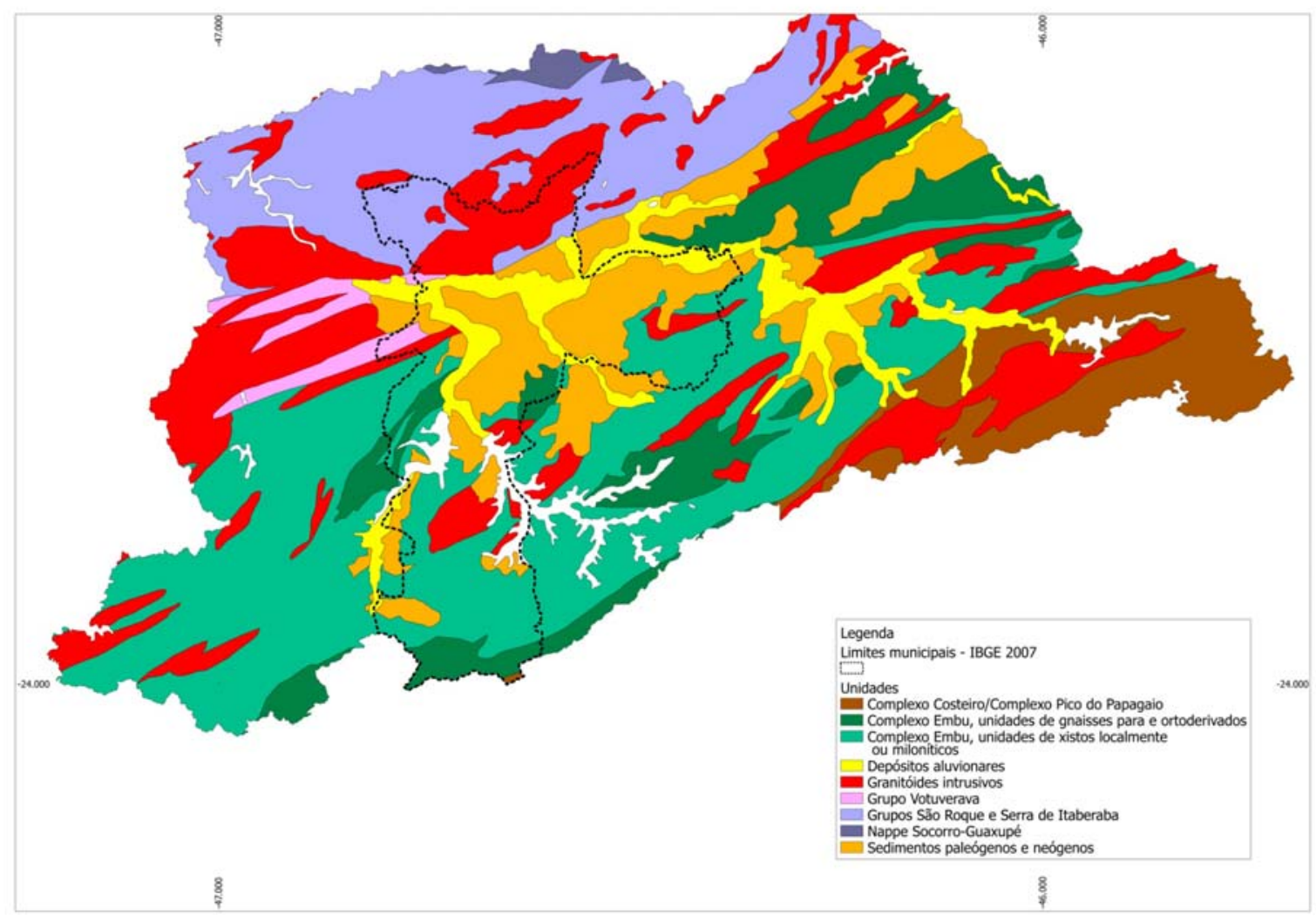

Figura 3 - Mapa geológico da Região Metropolitana de São Paulo com destaque para o embasamento. Fonte: Monteiro et al. (2012).

\section{Complexo Embu}

O Complexo Embu é a unidade com maior ocorrência no embasamento da bacia. Ocorre na porção centro-sul da Região Metropolitana de São Paulo, ocupando faixa de afloramentos com direção NE-SW, formado por xistos, filitos, migmatitos, gnaisses migmatizados e corpos lenticulares de quartzitos, anfibolitos e rochas calciossilicatadas. É limitado ao norte pelo sistema de falhas de Taxaquara e do Rio Jaguari e ao sul pela Falha de Cubatão, separando-o dos grupos São Roque e Serra do Itaberaba, e do Complexo Costeiro, respectivamente.

Segundo Juliani (1992), o Complexo Embu é composto por três conjuntos de litotipos: 
1. Rochas ortognáissicas polimigmatitizadas e polideformadas que constituem o Complexo Granito-Gnáissico-Migmatítico de Hasui (1994). Estes constituem o embasamento das supracrustais, com idades preliminares arqueanas a paleoproterozoicas. Hasui (1994) aponta a unidade como um conjunto de gnaisses de tipos diversos (porfiróides e homogêneos predominantes, bandados, subordinados e por vezes laminados), que se apresentam moderadamente migmatitizados (sob a forma de estruturas bandadas ou estromatíticas) e possuem enclaves esparsos e restritos de rochas metassedimentares e anfibolitos.

2. Rochas metassedimentares em grau metamórfico elevado, incluindo gnaisses com extensas faixas de xistos da fácies anfibolito médio a superior. Estes correspondem ao Complexo Embu de Fernandes (1991). Hasui (1994) aponta a ocorrência de metassedimentos de fácies anfibolito, representados por micaxistos, quartzitos e rochas cálciosilicáticas, com anfibolitos associados. Estas se apresentam moderadamente migmatitizadas com estruturas bandadas ou estromatíticas.

3. Sericita xistos e filitos de baixo grau metamórfico, caracterizados por Vieira (1989), que podem corresponder a porções das rochas metassedimentares supracitadas, que sofreram metamorfismo em condições de temperaturas mais baixas.

Segundo CPRM (2006), determinações geocronológicas foram realizadas por Cordani et al. (2002) em biotita gnaisses granodioríticos a tonalíticos, intercalados na unidade de xistos, localmente migmatíticos, próximos a São Lourenço da Serra. Uma idade de 811 × 13 Ma obtida pelo método U-Pb SHRIMP é relacionada à cristalização magmática do protólito granodiorítico-tonalítico. A partir de datações pelo método Th$\mathrm{U}-\mathrm{Pb}$, em microssonda eletrônica, monazitas extraídas de granada-sillimanita-biotita gnaisses da unidade paragnáissica e unidade de xistos, localmente migmatíticos, forneceram idades de $787 \pm 18 \mathrm{Ma}$ e $797 \pm 17 \mathrm{Ma}$, respectivamente, que 
correspondem à idade do metamorfismo principal (Vlach, 2001). Pelo mesmo método, o autor obteve idade de $594 \pm 21$ Ma na unidade paragnáissica, compatível com a colocação dos maciços graníticos tardios e com o metamorfismo principal do Terreno Serra do Mar de Campos Neto (2000). Idades aparentes em torno de 560 Ma, obtidas pelo método $\mathrm{Rb}-\mathrm{Sr}$, em pares feldspato e rocha total, por Cordani et al. (2002), são interpretadas como o final do metamorfismo regional e deformação dúctil.

\section{Grupos São Roque e Serra do Itaberaba}

Os grupos São Roque e Serra do Itaberaba, com ocorrência na área norte da Região Metropolitana de São Paulo, são constituídos por rochas metassedimentares e metavulcânicas, representadas por filitos, metarenitos e quartzitos, tendo secundariamente a ocorrência de anfibolitos, metacalcários, dolomitos, xistos porfiroblásticos e rochas calciossilicatadas (Rodriguez, 1998). Ao sul, esses grupos entram em contato, justapostos por falhas do sistema Taxaquara - Jaguari, com o Complexo Embu e, ao norte, pela Falha de Jundiuvira, são separados dos terrenos associados à Nappe Socorro-Guaxupé. Hasui (1994) aponta a ocorrência de metassedimentos de fácies xisto verde, representados por filitos, quartzitos e rochas cálciossilicáticas, com metabasitos associados.

Juliani \& Beljavskis (1995) colocam o Grupo São Roque acima das rochas do Grupo Serra do Itaberaba por contatos tectônicos. O ambiente de deposição do Grupo São Roque corresponde a um mar raso, em uma bacia de retro-arco, onde estariam representadas desde fácies deltaicas proximais até turbiditos de águas mais profundas, com atividade vulcânica subaquosa restrita (Bergmann, 1988). Segundo Juliani \& Beljavskis (1995), o Grupo São Roque foi submetido a metamorfismo na fácies xisto verde, alcançando maior grau metamórfico com a intrusão de granitóides ocorrida no Neoproterozoico.

Segundo Juliani (1993), as rochas do Grupo Serra do Itaberaba apresentam padrões de deformações de significativa complexidade, com superposição de eventos produzidos por processos regionais e deformações posteriores relacionadas às zonas de cisalhamento de Jundiuvira (contato com a Nappe Socorro-Guaxupé) e Rio Jaguari. 
A deposição do Grupo São Roque tem sido determinada por meio de datações U-Pb de rochas metavulcânicas ácidas e básicas (Henrique-Pinto \& Janasi, 2010) que ocorrem intercaladas na Formação Morro Doce (Carneiro et al. 1984), com idade de, aproximadamente, 1800 Ma, obtida por Van Schmus et al. (1986). Juliani et al. (2000) obteve pelo método U-Pb em zircões de metandesitos do Grupo Serra do Itaberaba, idade de cristalização de $1395 \pm 10$ Ma.

\section{Granitóides intrusivos}

Grande quantidade de batólitos a pequenos stocks de granitóides afloram na Região Metropolitana de São Paulo, alguns parcialmente cobertos pelas rochas sedimentares da Bacia de São Paulo. A maior resistência relativa ao intemperismo fez com que estas rochas sustentem altos morfológicos, que, de modo geral, não foram cobertos pelos sedimentos (Coutinho, 1980b).

Segundo Hasui et al. (1978) estes corpos são sin-tectônicos ou pós-tectônicos aos terrenos metamórficos adjacentes. Hasui (1994) classifica estas rochas como granitóides de tipos homogêneos e porfiróides, finos a muito grossos, de cores cinzaclaro a cinza-escuro e avermelhados.

Juliani (1992) menciona que a composição mineralógica dessas rochas varia de tonalítica a granítica, de acordo com Hasui et al. (1978), e é mais restrita, de granodiorítica a granítica, segundo Janasi \& Ulbrich (1991). As rochas em geral apresentam-se fracamente foliadas internamente aos maciços e com bordas sempre associadas a zonas de falhas. Biotita é o mineral máfico principal e hornblenda é subordinada. Também é registrada a ocorrência de granitos como pequenos stocks peraluminosos.

Inúmeros plútons isolados devem constituir satélites dessas grandes massas graníticas, tendo em vista as semelhanças composicionais e de idade (Janasi \& Ulbrich 1991). Estes granitóides apresentam, em sua maioria, tendência calcialcalina potássica, predominando as composições monzogranítica, granodiorítica, monzodiorítica e diorítica (CPRM, 2006). 


\section{Unidades de ocorrência restrita}

Os terrenos da Nappe Socorro-Guaxupé, o Complexo Costeiro, o Complexo Pico do Papagaio e o Grupo Votuverara são unidades de ocorrência restrita na Região Metropolitana de São Paulo.

Os terrenos a norte da Falha de Jundiuvira correspondem à Nappe SocorroGuaxupé (Campos Neto, 2000). Rodriguez (1998), em referência à antiga denominação da unidade aflorante nesta área (Grupo Amparo), menciona que estas rochas são representadas por metassedimentos e rochas gnáissicas e migmatíticas.

O Complexo Costeiro ocorre no extremo leste-sudeste da Região Metropolitana de São Paulo, separado do Complexo Embu pela Falha de Cubatão. Segundo Rodriguez (1998) a unidade é constituída por migmatitos policíclicos de paleossoma gnáissico e ocorrem como migmatitos e gnaisses graníticos porfiroblásticos milonitizados, biotita gnaisses e gnaisses peraluminosos. Segundo CPRM (2006), o corpo limitado pelas zonas de cisalhamento Itariri e Cubatão, no extremo oeste da área de afloramento do Complexo Costeiro, foi referido por Passarelli (2001) como granito tipo Itariri. Trata-se de biotita monzogranito, localmente tonalítico, foliado, com megacristais de feldspato. O conteúdo mineralógico é composto por quartzo, microclínio, plagioclásio e biotita. Localmente apresenta camadas quartzo-feldspáticas intercaladas com bandas máficas e feições migmatíticas.

O Complexo Pico do Papagaio ocorre no extremo leste da Região Metropolitana de São Paulo. Segundo CPRM (2006) é uma unidade representada por granitóides calcialcalinos, foliados, intrudidos no Complexo Costeiro ao longo de zona de cisalhamento de orientação NE-SW, de forma concordante com a estruturação das encaixantes. O litotipo predominante é hornblenda-biotita granitoide gnáissico.

O Grupo Votuverava ocorre na região oeste da RMSP, em sua unidade terrígena, como encaixante do granito Itapevi. Segundo CPRM (2006), predominam, nesta unidade, metassiltitos, maciços a muito foliados, que preservam acamamento, com estratificações plano-paralelas e cruzadas e granodecrescência ascendente, com 
alternância de metargilitos, metarenitos lenticulares e metaconglomerados polimíticos.

\subsubsection{Preenchimento sedimentar paleógeno e neógeno}

O preenchimento sedimentar da Bacia de São Paulo corresponde a deposição paleógena do Grupo Taubaté (Formação Resende, Formação Tremembé e Formação São Paulo) e neógena da Formação Itaquaquecetuba (Figura 4).

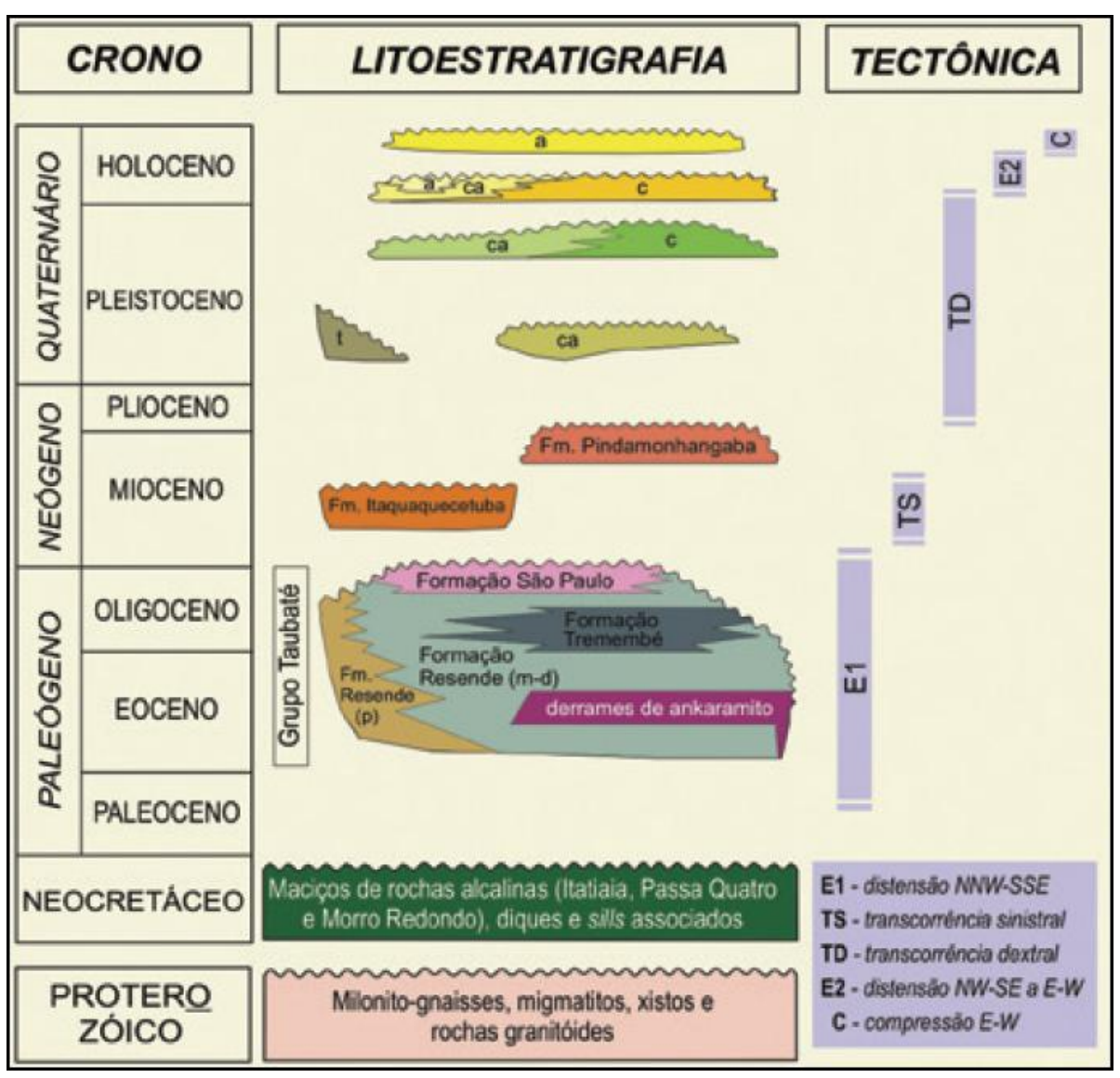

Figura 4 - Quadro litoestratigráfico e evolução tectono-sedimentar do segmento central do RCSB Letras: $p$ - leques aluviais proximais; $m-d$ - leques aluviais medianos a distais associados a planície aluvial de rios entrelaçados; $\mathrm{t}$ - depósitos de tálus; c - depósitos coluviais; ca - depósitos colúvio-aluviais; a depósitos aluviais. Fonte: Riccomini et al. (2004).

A Bacia de São Paulo é uma bacia do tipo rift, retrabalhada por falhas póssedimentares que causaram soerguimentos e abatimentos locais de seu substrato (Figuras 5 e 6). A julgar pelo seu formato e distribuição de fácies sedimentares, podese considerar que a bacia era originalmente um hemigráben, controlado por falhas 
normais reativadas ao longo das zonas de cisalhamento de Taxaquara e Jaguari, dispostas ao longo de sua borda norte (Riccomini \& Coimbra, 1992).

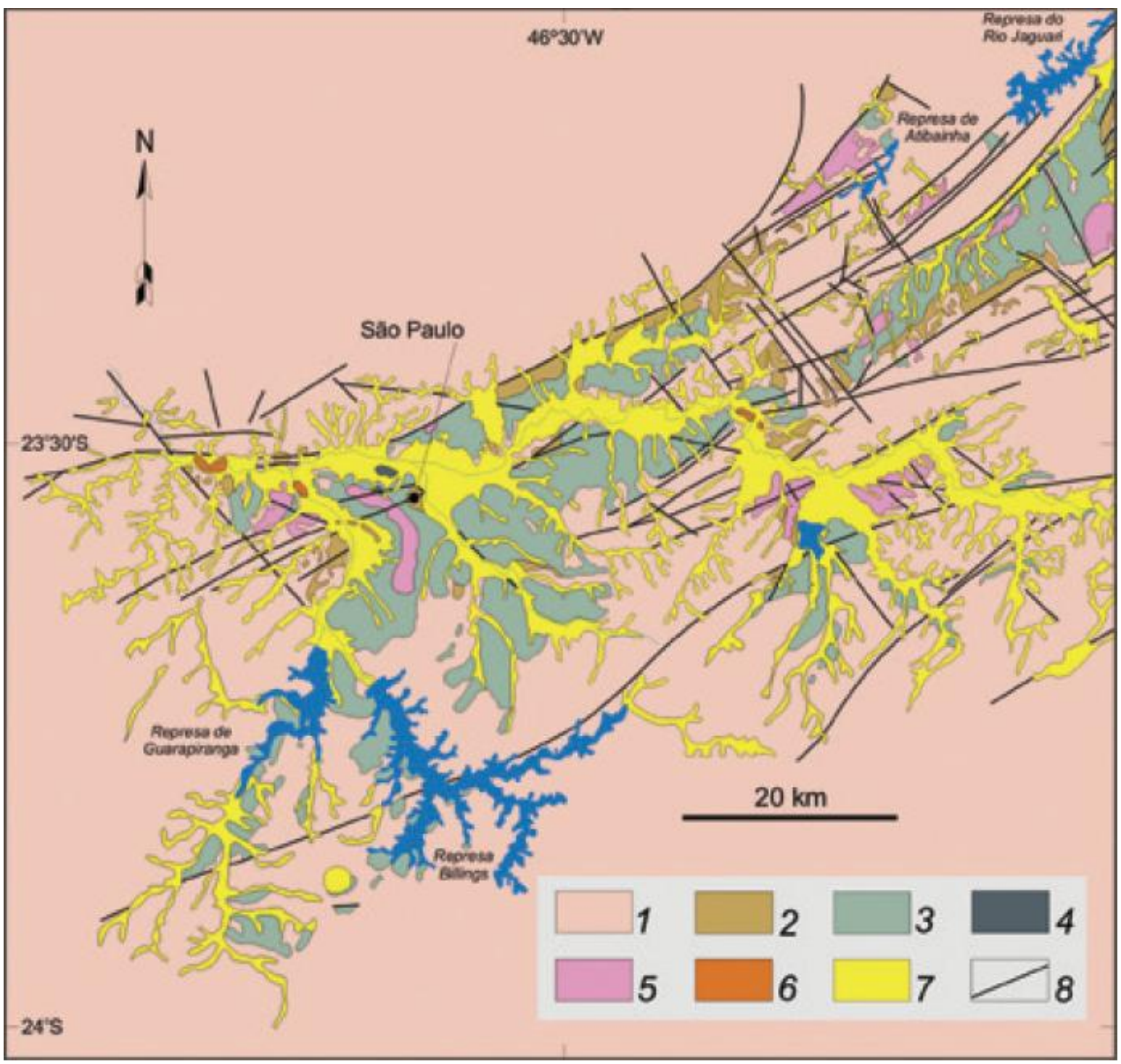

Figura 5 - Mapa geológico da Bacia de São Paulo e porção sudoeste da Bacia de Taubaté - 1) embasamento pré-cambriano; 2) Formação Resende (sistema de leques aluviais proximais); 3) Formação Resende (sistema de leques aluviais medianos a distais associados a planície aluvial de rios entrelaçados); 4) Formação Tremembé; 5) Formação São Paulo; 6) Formação Itaquaquecetuba; 7) sedimentos quaternários; 8) falhas cenozoicas, em parte reativadas do embasamento pré-cambriano. Fonte: Ricomini et al. (2004). 


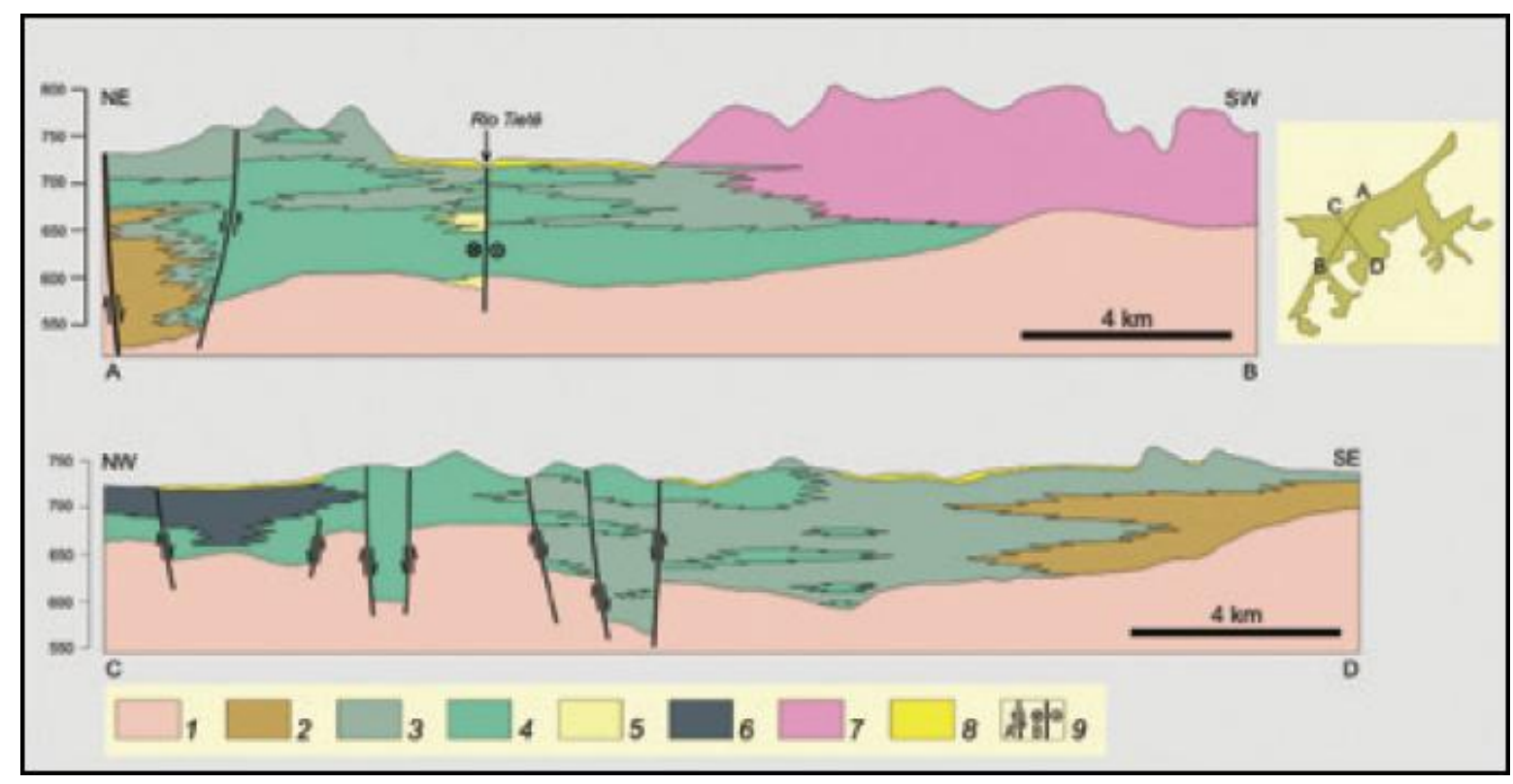

Figura 6 - Seções geológicas na Bacia de São Paulo construídas a partir de dados de sondagens para água subterrânea e observações de superfície - 1) embasamento pré-cambriano; 2) orto- e paraconglomerados de leques aluviais proximais da Formação Resende; 3) lamitos de leques aluviais medianos a distais da Formação Resende; 4) lamitos de leques aluviais distais e, principalmente, areias e conglomerados de sistema fluvial entrelaçado da Formação Resende; 5) predominância de areias grossas e conglomerados de sistema fluvial entrelaçado da Formação Resende; 6) sistema lacustre da Formação Tremembé; 7) sistema fluvial meandrante da Formação São Paulo; 8) aluviões quaternários; 9) falha normal (A) e falha transcorrente dextral (B). Para localização das seções na bacia ver esquema no canto superior direito da figura. Fonte: Riccomini et al. (2004).

\section{Características da sedimentação em bacias tipo rift}

A maioria dos modelos de preenchimento de bacias do tipo rift (Gawthorpe \& Colella, 1990; Leeder, 1995; Leeder \& Gawthorpe, 1987) descreve, nas fases iniciais de estiramento, uma série de pequenas bacias onde são desenvolvidas drenagens, que alimentam pequenos pântanos e sistemas fluviais axiais sem a presença de conglomerados sintectônicos. Nesta fase a zona principal de subsidência ainda não está definida e a ocorrência da trama de falhas é incipiente.

A seguir, a sedimentação passa a ocorrer em ambiente predominantemente lacustre com intensa atividade tectônica em diversas sub-bacias desconectadas. Neste momento, chega ao fim a sedimentação em lago profundo e, conforme a atividade tectônica vai se tornando moderada, inicia-se a deposição em lago raso. A subsidência concentra-se no depocentro, altos internos são soterrados e a bacia aumenta a área de sedimentação passando a ocorrer progressões flúvio-deltaicas. 
A sedimentação das fossas tectônicas é efetuada a partir de drenagens que se estabelecem tanto na margem flexural quanto na margem falhada, sendo que nesta última as drenagens são de pequena extensão e desenvolvem leques aluviais de dimensões restritas que se alternam a praias restritas. Já nas zonas de acomodação, estruturalmente heterogêneas, ocorrem pequenos leques deltaicos e depósitos bioclásticos ao longo das áreas elevadas, enquanto nos baixos se depositam lamas carbonáticas e clastos finos.

Ao final do ciclo tectônico a atividade se torna mais branda, nas zonas flexurais se desenvolvem sistemas deltaicos que progradam transversalmente à bacia em direção ao depocentro. Estes se assemelham àqueles que mais tarde precederão o desenvolvimento de possante sistema fluvial ao longo do eixo do rift e que representam a fase de lago assoreado.

A unidade estrutural básica de um rift é um hemi-gráben, que é composto basicamente por uma rampa de declive variável e uma falha de borda, conferindo-se a aparência de uma cunha (Figura 7), sendo comum a ocorrência de hemi-grábens adjacentes (Kuchle et al., 2005).

Para Gawthorpe \& Colella (1990), a localização de deltas de granulometria grossa em bacias rift (Figura 8) está relacionada ao controle estrutural topográfico e batimétrico, que, por sua vez, controla a localização dos depocentros, pontos de entrada e potencial de produção de sedimentos. Este controle é marcante ao longo da escarpa do bloco de piso ou lapa (footwall), onde as drenagens são originadas e correm para a bacia, situada no bloco de teto ou capa (hangingwall). 


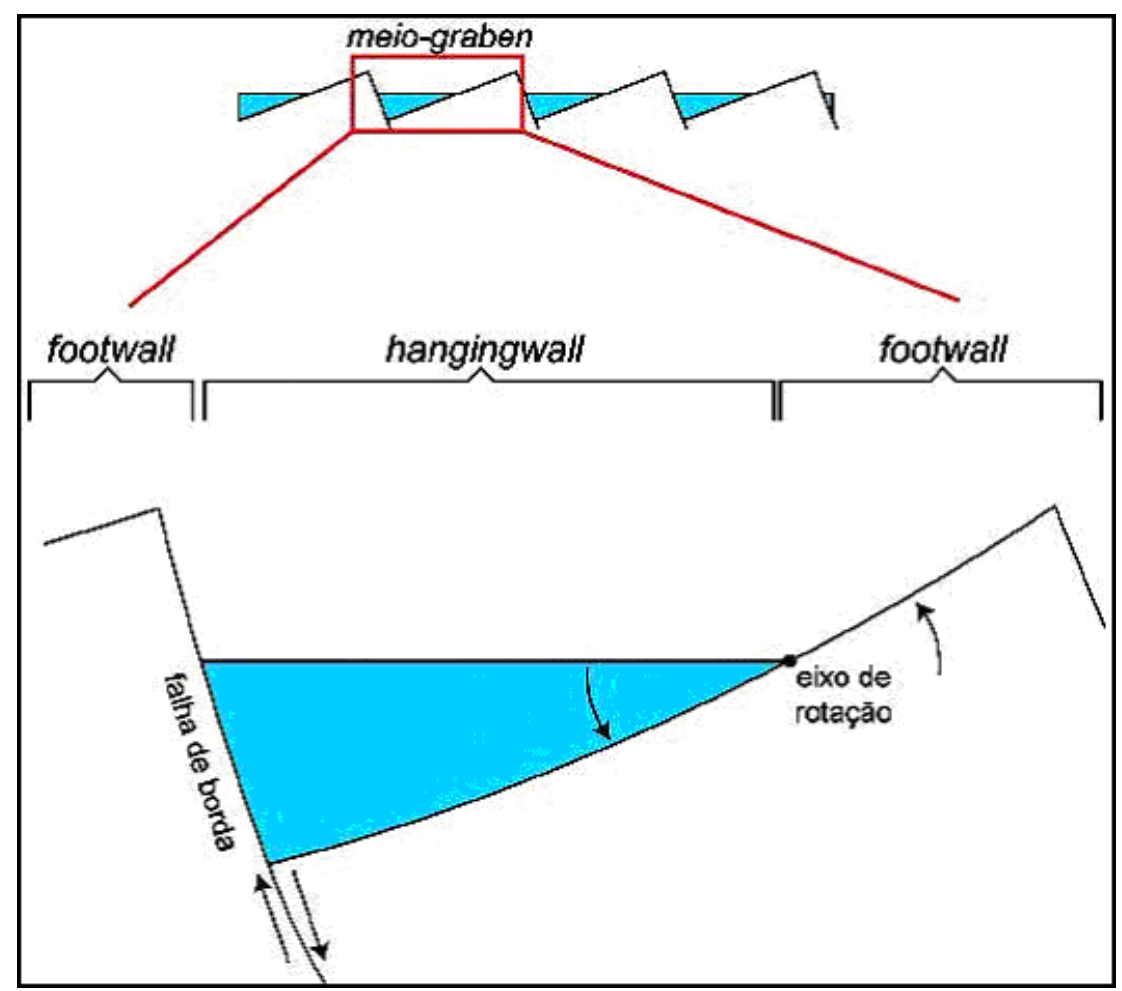

Figura 7 - Esquema básico de um meio-gráben. Fonte: Modificado de Kuchle et al., 2005.

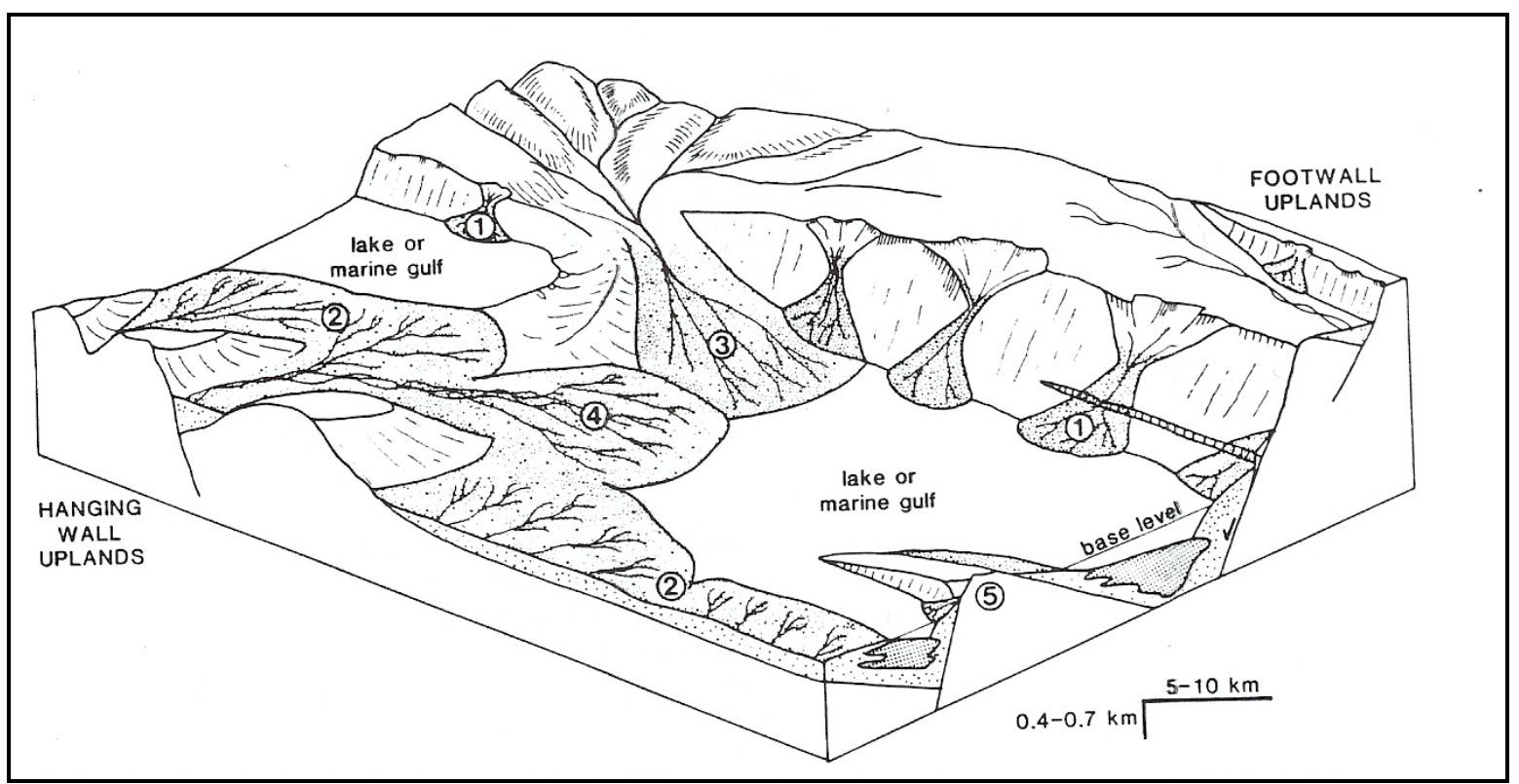

Figura 8 - Bloco diagrama esquemático ilustrando as características de localização dos deltas de granulometria grossa para bacias rift modernas e antigas. (1) Deltas originados nas terras altas de footwal - drenagens desenvolvidas ao longo da borda da zona de falha. (2) Deltas originados nas terras altas de hanging wall, formando uma franja relativamente constante ao longo da encosta. (3) Delta selecionado proveniente da zona flexural de transferância, que separa os dois segmentos de borda da falha. (4) Delta axial. (5) Delta originado no bloco de falha intra-bacia. Nota: Em muitas bacias rift, o baixo gradiente do hanging wall e encostas axiais promovem o desenvolvimento de sistemas deposicionais fluvio-deltaicos, mais finos. Fonte: Gawthorpe \& Colella, 1990. 
Os parâmetros controladores de uma bacia rift são relacionados a tectônica, clima, aporte sedimentar, espaço de acomodação, magmatismo e eustasia (Kuchle et al., 2005).

A tectônica é considerada como um fator fundamental de controle de uma bacia rift, pois praticamente todo o espaço de acomodação gerado é associado a pulsos tectônicos, bem como a destruição de espaços no caso da subsidência e soerguimento no sistema de hemi-gráben.

O clima é um fator controlador para o preenchimento e preservação de bacia rift, ao limitar as taxas de transporte e acumulação, taxas de intemperismo e erosão, composição clástica, produção de carbonatos, precipitação de evaporitos, variação do nível do lago e diagênese.

O aporte sedimentar controla o preenchimento de um rift e define os padrões de empilhamento, pois estes são descritos na forma de uma relação entre o aporte sedimentar e o espaço de acomodação. O espaço de acomodação é diretamente dependente da tectônica, sendo considerado fundamental para a geração, preenchimento e preservação de bacias rift.

A ocorrência de magmatismo é um forte indicativo de rift ativo. Em rifts que ocorrem dominantemente sobre a crosta continental é comum a geração de lagos interiores raramente conectados ao oceano, o que torna as variações eustáticas muito subordinadas às outras variáveis anteriormente enunciadas.

A Bacia de São Paulo, no contexto do Rift Continental do Sudeste do Brasil, apresenta os leques aluviais relacionados à Formação Resende, os depósitos lacustres pouco expressivos relacionados à Formação Tremembé, e depósitos fluviais relacionados as formações Resende, São Paulo e Itaquaquecetuba. O magmatismo que indica que este rift é ativo não foi observado na Bacia de São Paulo, somente nas bacias de Itaboraí e Volta Redonda, que fazem parte do mesmo sistema, porém seus efeitos podem ser também percebidos na Bacia de São Paulo, conforme descrito a seguir. 


\section{Formação Resende - Grupo Taubaté}

A Formação Resende, unidade basal e lateral do Grupo Taubaté, é constituída por um sistema de leques aluviais associados à planície fluvial de rios entrelaçados. Foi definida na Bacia de Resende, onde está localizada sua seção-tipo (Amador, 1975; Riccomini, 1989). Segundo Riccomini \& Coimbra (1992) esta formação apresenta distribuição generalizada e pode chegar a $80 \%$ do preenchimento sedimentar da Bacia de São Paulo, com espessura estimada em $256 \mathrm{~m}$.

Esta formação compreende duas litofácies principais. A primeira litofácies encerra conglomerados polímiticos, interdigitados com arenitos e lamitos arenosos e corresponde aos leques aluviais proximais, situados nas proximidades do contato com o embasamento. A segunda litofácies compreende arenitos intercalados com lamitos e corresponde aos leques aluviais em posição distal, associados a rios entrelaçados. Nestes ocorrem esmectitas detríticas (argilomineral do tipo expansivo), consideradas como indicadores de semi-aridez climática e drenagem ineficaz, subordinadamente caulinitas e cloritas.

Calcrete calcítico (caliche), preenchendo rachaduras de ressecamento em lamitos argilosos foi identificado nas obras de extensão norte da Linha 1 (azul) do Metropolitano de São Paulo, sendo interpretado como paleossolo formado também sob condições de semi-aridez climática, semelhante aos identificados nas bacias de Curitiba, Taubaté e Resende (Riccomini \& Coimbra, 1992; Riccomini et al. 2004).

\section{Formação Tremembé - Grupo Taubaté}

A Formação Tremembé, depositada em ambiente lacustre do tipo playa-lake (Riccomini, 1989), interdigita-se lateral e verticalmente com os depósitos da Formação Resende. Esta formação tem ocorrência mais significativa da porção central da Bacia de Taubaté, onde está localizada sua seção-tipo.

Na Bacia de São Paulo, com espessura estimada em 60m, esta formação compreende camadas tabulares de argilitos verdes maciços intercalados com argilitos 
cinza-escuro a preto, ricos em matéria orgânica, identificados na escavação da Estação Barra Funda da Linha 3 (vermelha) do Metropolitano de São Paulo e em sondagens nas proximidades do Parque Antártica e na Rua do Oriente no Pari (Riccomini \& Coimbra, 1992).

\section{Formação São Paulo - Grupo Taubaté}

A Formação São Paulo, unidade de topo do Grupo Taubaté, tem sua principal área de exposição no espigão central da cidade, por onde passam as avenidas Paulista, Doutor Arnaldo, Domingos de Morais e Heitor Penteado, além de exposições distribuídas do aeroporto de Congonhas ao Jabaquara e na área oeste da cidade, na região do Jaguaré e Cidade Universitária. A seção-tipo está localizada nos arredores da Av. Heitor Penteado (Riccomini, 1989). Outras ocorrências mais restritas são verificadas no Alto de Santana e na região entre o Anhangabaú e o Pátio do Colégio (Riccomini \& Coimbra, 1992).

Esta formação compreende um sistema fluvial meandrante (Riccomini, 1989), sendo as principais fácies sedimentares compostas por arenitos grossos, conglomeráticos, com abundante estratificação cruzada, base erosiva e presença de clastos argilosos representantes de canais meandrantes; siltitos e argilitos laminados, podendo conter registro fossilífero (linhitos), depositados em meandros abandonados; arenitos médios e grossos proveniente do rompimento de diques marginais; gradando para sedimentos mais finos rítmicos e laminados, típicos de planície de inundação.

A Formação São Paulo sobrepõe-se transicionalmente ao sistema de leques aluviais da Formação Resende, indicando mudança para condições paleoclimáticas mais úmidas e redução na atividade tectônica, embora ocasionalmente pulsos tectônicos resultem em delgadas intercalações de lamitos provenientes de leques aluviais.

São frequentes nas interfaces entre as fácies argilosas e arenosas a presença de couraças limoníticas com espessuras variáveis (Riccomini \& Coimbra, 1992), conferindo 
pronunciada impermeabilidade no topo das camadas mais finas, sendo comum surgências das águas que percolam os pacotes arenosos. Nas exposições superficiais da Formação São Paulo é frequente a ocorrência de uma camada argilosa com coloração avermelhada e aspecto homogêneo, conhecida no meio geotécnico como "argilas porosas". Esta camada é resultante de processos pedogenéticos e laterização, com espessura estimada em até $10 \mathrm{~m}$.

\section{Formação Itaquaquecetuba}

A Formação Itaquaquecetuba representa um sistema fluvial entrelaçado, restrito à área geográfica da Bacia de São Paulo, que ocorre assentado diretamente sobre rochas do embasamento pré-cambriano, sem que tenha sido verificada a sua relação com as unidades sedimentares paleógenas. Este sistema ocorre sob os aluviões holocênicos dos rios Tietê, Pinheiros e Tamanduateí. A seção-tipo está localizada no município epônimo, em um porto de areia na margem direita do rio Tietê, com espessura estimada em 50m (Coimbra et al., 1983; Riccomini, 1989).

A deposição da unidade foi controlada por falhas de direção ENE e NNW (Almeida, 1983; Riccomini, 1989), em cujas vizinhanças formaram-se cunhas clásticas contendo brechas polimíticas e megaclastos. Nas partes distais das cunhas ocorrem lamitos arenosos, com intercalações de arenitos maciços, por vezes com estruturas resultantes de liquefação (Riccomini, 1989). Na parte central das bacias têm-se depósitos fluviais entrelaçados, típicos da unidade, que incluem arenitos arcoseanos com estratificação cruzada acanalada e tabular de grande porte, contendo conglomerados basais com seixos de quartzo e quartzito arredondados de barras longitudinais de canais, ou brechas com fragmentos de argilitos.

\subsubsection{Coberturas sedimentares quaternárias}

São consideradas coberturas quaternárias os depósitos de idade pleistocênica a holocênica (atual). Estes depósitos correspondem a associações colúvio-aluviais com 
espessura e distribuição relativamente restrita, predominantemente próximas às drenagens atuais.

Os depósitos pleistocênicos compreendem predominantemente coluviões argilo-arenosos, com lentes argilosas a conglomeráticas, ocasionalmente contendo madeira fóssil, e aluviões subordinados constituídos por conglomerados basais sobrepostos por areias grossas a conglomeráticas com estratificações cruzadas, gradando para areias médias a finas, com porções argilosas (Melo et al., 1987).

Os depósitos holocênicos são representados por coluviões e aluviões, com espessuras geralmente inferiores a 10m. Os coluviões são descontínuos, embora com distribuição generalizada, podendo conter cascalheiras (stone lines) na base. Os depósitos aluviais estão depositados em várzeas e baixos terraços, constituídos por camadas arenosas e argilosas ricas em matéria orgânica, geralmente exibindo cascalheiras na base.

\subsubsection{GEOLOGIA ESTRUTURAL E TECTÔNICA}

Os primeiros modelos propostos para a geração da Bacia de São Paulo e do RCSB apresentavam argumentação baseada na geomorfologia, com origem tectônica ou erosiva. A partir da década de 1970 tomam força os modelos tectônicos, que consideraram as depressões que abrigam as bacias originadas pela reativação cenozoica de antigas zonas de cisalhamento proterozoicas, vinculada à evolução da margem continental.

Diversos estudos foram desenvolvidos na sequência. Riccomini (1989), com base na análise das estruturas tectônicas e suas relações estratigráficas com 0 preenchimento sedimentar, elaborou o primeiro modelo tectônico contemplando os tectonismos gerador e modificador para o segmento central do RCSB, que inclui as Bacias de São Paulo, Taubaté, Resende e Volta Redonda (Figura 7). Concluiu que a formação da depressão original do rift e concomitante preenchimento sedimentar e vulcânico teriam ocorrido no Paleógeno, sob a ação de um campo de esforços 
distensivo de direção NNW-SSE, causador da reativação, como falhas normais, de antigas zonas de cisalhamento proterozoicas de direção NE a ENE.

O modelo é sustentado pelo caráter normal das falhas mestras ativas durante a instalação do segmento central do RCSB, pelas direções de distensão obtidas a partir dos dados de falhas estriadas - sempre em posição ortogonal às falhas de borda das bacias - e também pela contiguidade entre os depósitos de leques aluviais proximais e as áreas fontes vizinhas.

Estudos realizados em rochas do substrato do RCSB identificaram a atuação de um regime transcorrente sinistral, com compressão de direção NE-SW e distensão NWSE, afetando corpos alcalinos neocretáceos, no sul do Estado de São Paulo (Riccomini, 1995) e na região do Gráben da Guanabara (Ferrari, 2001), com idade neocretácea a paleocena.

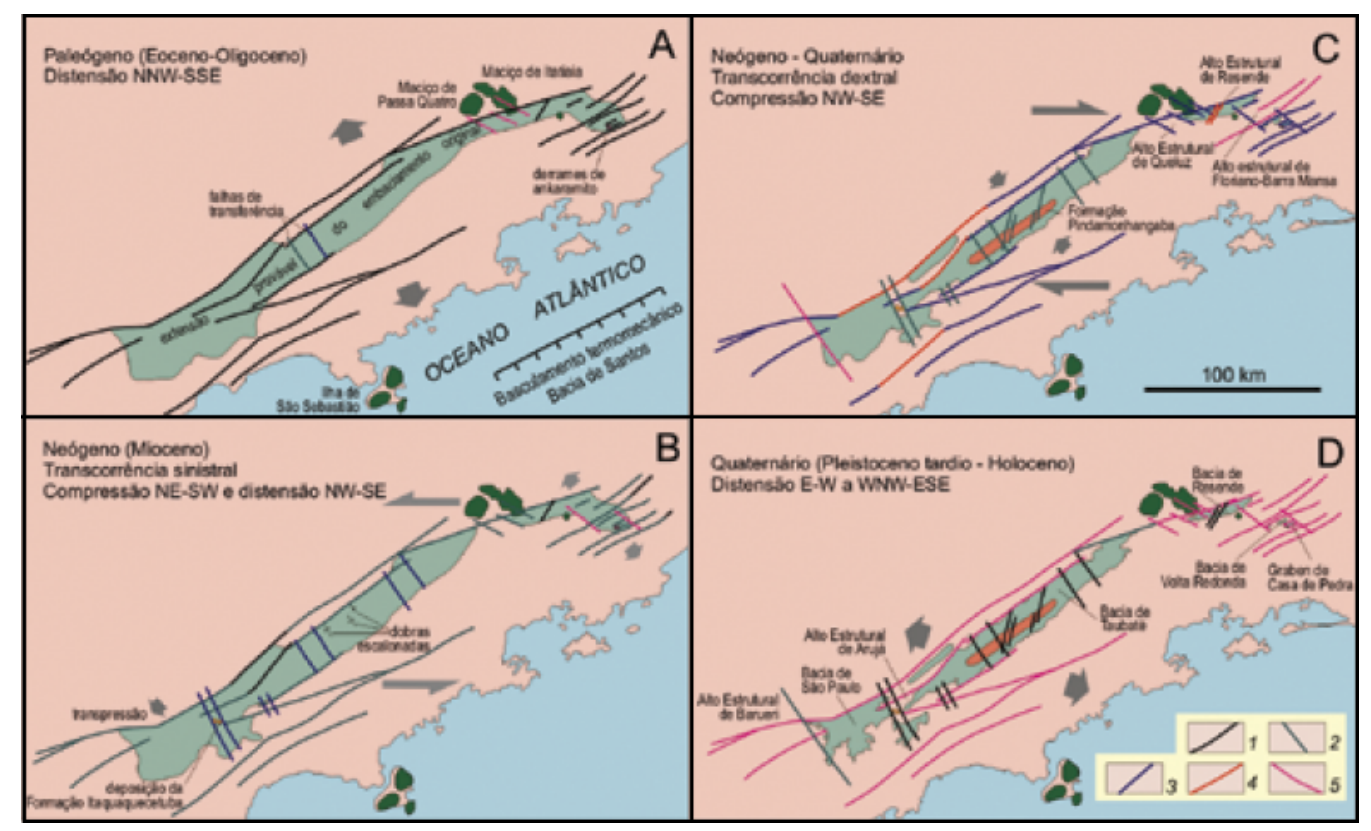

Figura 7 - Esboços paleotectônicos da evolução do segmento central do RCSB - Legenda no quadro D: 1) falhas de componente predominante normal; 2) falha de componente transcorrente sinistral; 3) falha de componente transcorrente dextral; 4) falha de componente predominante reversa; 5) falha com movimentação não caracterizada. Fonte: Riccomini et al. (2004)

Segundo Riccomini (1989) e Salvador \& Riccomini (1995) as fases tectônicas deformadoras envolveriam novas reativações ao longo das falhas preexistentes e, em menor escala, geração de novas estruturas (Figura 7). Os eventos deformadores 
compreenderiam, sucessivamente: 1) transcorrência sinistral de direção E-W, com distensão NW-SE e, localmente, compressão NE-SW, de idade neogênica; 2) transcorrência dextral, com compressão NW-SE, de idade quaternária; 3) distensão de direção WNW-ESE e idade pleistocênica a holocena; e 4) Compressão E-W, de idade holocena.

Ao primeiro evento deformador estão relacionadas falhas transcorrentes ou de empurrão, estas por vezes colocando blocos de rochas do embasamento sobre os depósitos sedimentares e aquelas controlando a instalação de bacias de afastamento de pequenas dimensões - Formação Itaquaquecetuba na sua área-tipo (Riccomini, 1989). Este evento foi também o responsável pela geração de dobras cônicas quilométricas na porção central da Bacia de Taubaté.

Durante o segundo evento deformador as falhas das bordas das bacias, ativas na fase de instalação do rift, foram reativadas com caráter transcorrente, inverso e/ou de empurrão, localmente cavalgando depósitos sedimentares paleogênicos. Neste evento teriam sido afeiçoados os altos estruturais que atualmente separam o registro sedimentar paleogênico em bacias isoladas.

O terceiro evento deformador, de caráter distensivo, parece ter dado o contorno atual da distribuição dos sedimentos. O último evento deformador, compressivo, causou a reativação inversa de falhas de direções próximas de N-S e a geração de famílias de juntas conjugadas de cisalhamento em depósitos colúvioaluviais.

As variações nos campos de esforços relacionados ao tectonismo deformador decorreriam do balanço entre o ridge-push e slab-pull da Placa Sul Americana, respectivamente em relação às placas Africana e de Nazca (Riccomini et al., 2004). Considerando-se as direções estruturais preferenciais do RCSB, segundo NE, em relação à trajetória da Placa Sul Americana, para $W$, ocorreria transcorrência dextral e compressão (transpressão) quando o ridge-push superasse o slab-pull, e transcorrência sinistral e distensão (transtração) no caso oposto (Riccomini, 1989). Há ainda outros 
fatores, tais como a carga de sedimentos na Bacia de Santos, a presença de soerguimentos regionais e a ascensão do nível do mar após a glaciação do Pleistoceno terminal que provavelmente interferiram no balanço dos esforços envolvidos.

\subsubsection{HIDROTERMALISMO}

Sant'Anna \& Riccomini (2001), ao caracterizarem amostras com cimentação hidrotermal nas formações Itaboraí, Macacu (Bacia de Itaboraí) e Resende (bacias de São Paulo e Taubaté), descreveram: 1) lâminas, drusas e vênulas de quartzo nos calcários da Fm. Itaboraí; 2) opala-CT disseminada em lamitos da Fm. Macacu; 3) caulinita e opala-CT preenchendo a porosidade primária e recobrindo grãos detríticos das rochas da Fm. Resende; e 4) barita preenchendo fraturas ou recobrindo clastos de conglomerados e arenitos da Fm. Resende.

Na Formação Resende, com exceção da barita, a cristalização destes cimentos foi penecontemporânea à sedimentação eocênica (Sant'anna \& Riccomini, 2001). Em todas as unidades a cimentação ocorreu sob a atuação de controles estruturais (exercidos por falhas e fraturas preexistentes ou em nucleação nos sedimentos) e litológicos (devido a diferença na porosidade e permeabilidade das camadas).

Durante a principal fase de desenvolvimento do RCSB, no Eoceno, o contexto geológico regional apresentava condições favoráveis para a circulação de soluções hidrotermais e cimentação, incluindo regime distensivo de direção NNW-SSE que propiciou abertura de falhas ENE a NE, aumento do fluxo térmico regional e magmatismo (Sant'Anna \& Riccomini, 2001), evidenciado em derrames ankaramíticos (Klein \& Valença, 1984; Riccomini \& Rodrigues-Francisco, 1992; Riccomini et al., 1983) nas bacias de Itaboraí e Volta Redonda.

Na Bacia de São Paulo foram observadas no Largo da Batata (Estação Faria Lima do Metrô), ao longo da Avenida Anhaia Mello na Vila Prudente, nas escavações da Estação Adolfo Pinheiro da Linha 5, na região de Santo Amaro e na região do Parque Dom Pedro II (Riccomini et al., 1988). Em geral são arenitos ou lamitos cimentados, 
com elevada resistência à compressão, implicando em maior dificuldade de escavação em relação ao restante do pacote sedimentar. Na maioria dos casos, a amostragem por sondagem somente é realizada com o emprego de ferramenta rotativa, pois a rocha é impenetrável à percussão.

\section{ASPECTOS GEOTÉCNICOS DA BACIA DE SÃO PAULO}

\subsection{HISTÓRICO DOS TRABALHOS}

Segundo Vargas (2002) a exploração do subsolo de São Paulo, sob interesse tecnológico, teve início com a perfuração de poços para utilização da água subterrânea, porém com reconhecimento precário das camadas.

A partir da década de 30, o Instituto de Pesquisas Tecnológicas (IPT) iniciou o reconhecimento do subsolo através de sondagens com medidas de resistência à penetração com a finalidade de conhecer o comportamento do solo para fundações de pontes e edifícios.

O número de sondagens e amostras coletadas na região central de São Paulo passa a aumentar de acordo com o avanço das obras, tornando possível a publicação, na década de 40, do trabalho de Vargas \& Bernardo (1945) sobre os solos do centro da cidade. Neste período também teve início as investigações com sondagens e ensaios na região da Avenida Paulista, realizadas pelo IPT a pedido da Prefeitura de São Paulo para fins de projeto das fundações de edifícios (Vargas, 2002). Pichler (1948) apresentou na 2a Conferência Internacional de Mecânica dos Solos o estudo regional dos solos de São Paulo.

Vargas (1951) apresentou um trabalho sobre a carga de pré-adensamento das camadas de São Paulo utilizando dados de ensaios em "argilas variegadas" e "argilas porosas" do centro da cidade. Posteriormente, Vargas (1953) abordou os problemas nas fundações dos edifícios. 
A partir da década de 60 há um novo impulso nas investigações geotécnicas em São Paulo, em decorrência dos projetos das primeiras linhas do Metrô. Os primeiros estudos da Linha 1- Azul do metrô foram apresentados por Cozzolino \& Chiossi (1969), em trabalho intitulado "A Bacia Sedimentar de São Paulo".

A tese de doutoramento de Cozzolino (1972) utiliza os dados de sondagens e ensaios de caracterização geotécnica das linhas 1 -Azul e 3 - Vermelha do Metrô de São Paulo, além de outras fontes, para identificar os tipo de rochas sedimentares que constituem a Bacia de São Paulo. Em 1974 a Companhia do Metropolitano de São Paulo editou uma comunicação que reunia os ensaios e as principais conclusões das investigações geotécnicas para o projeto e construção das Linhas do Metrô, elaborada por Vera Cozzolino e Victor de Mello.

Em 1980 a Associação Brasileira de Geologia de Engenharia (ABGE) e a Sociedade Brasileira de Geologia (SBG) organizaram uma Mesa Redonda sobre "Aspectos geológicos e geotécnicos da Bacia Sedimentar de São Paulo" reunindo os principais autores e estudos geotécnicos disponíveis no momento da publicação.

Em 1989 houve novo encontro sobre a Geologia da Bacia de São Paulo, organizado pelo Núcleo São Paulo da Sociedade Brasileira de Geologia e Instituto de Geociências da Universidade de São Paulo.

Em 1992, a Associação Brasileira de Mecânica dos Solos (ABMS) editou a publicação "Solos da Cidade de São Paulo", reunindo novamente os principais autores e trabalhos na área geotécnica e relatando a evolução dos conhecimentos do período. Rocha (1995) estudou as características dos arenitos terciários e as implicações para as obras subterrâneas.

Por fim, em 2012 a ABMS realizou uma nova reunião de autores no seminário "Twin Cities - Solos das regiões metropolitanas de São Paulo e Curitiba" com um trabalho de revisão e análise contemplando dados geológicos, hidrogeológicos, geotécnicos e provenientes da experiência em fundações e túneis. 


\subsection{AS INFORMAÇÕES ADVINDAS DAS OBRAS METROVIÁRIAS NA BACIA DE SÃO PAULO}

A experiência na execução de obras para a Companhia do Metropolitano de São Paulo - Metrô resultou num aprimoramento do conhecimento geológicogeotécnico da região, inclusive com a implementação de um sistema de classificação geológico-geotécnica utilizada nos projetos das linhas, inspirado na proposta de classificação e notação de litotipos apresentada por Kutner \& Bjornberg (1997). Este sistema se configura como uma classificação de nomenclatura objetiva e de rápida aplicação aos constituintes das unidades geológico-geotécnicas mais comuns na Bacia de São Paulo.

Posteriormente, nos estudos do Metrô de São Paulo, foi feita uma contribuição ao modelo de Kutner \& Bjornberg (1997), inicialmente aplicada no Projeto Básico da Linha 4 - Amarela e vem sendo utilizada em todos os seus projetos desde o Projeto Básico da Linha 5 - Lilás (Figura 8).

Este sistema de classificação permite identificar os principais compartimentos geológicos da Bacia de São Paulo, porém não contempla as formações Tremembé e Itaquaquecetuba, além dos depósitos coluviais, por apresentarem ocorrência restrita ou estarem ausentes nos projetos das linhas do Metrô.

Diversos estudos e ensaios geotécnicos foram executados para os projetos das linhas do Metrô, destacando-se a obtenção dos principais parâmetros geotécnicos para as camadas identificadas na Figura 8 , tais como peso específico $(\gamma)$, resistência efetiva dada pela coesão $\left(c^{\prime}\right)$ e ângulo de atrito interno $\left(\phi^{\prime}\right)$, módulo de deformabilidade tangente inicial $\left(E_{0}\right)$, módulo de elasticidade $(E)$, coeficiente de Poisson $(v)$, coeficiente de empuxo em repouso $\left(K_{0}\right)$, coeficiente de apoio elástico horizontal (Kh), coeficiente de permeabilidade (K), índice de compressão (Cc) e coeficiente de adensamento (Cv). 


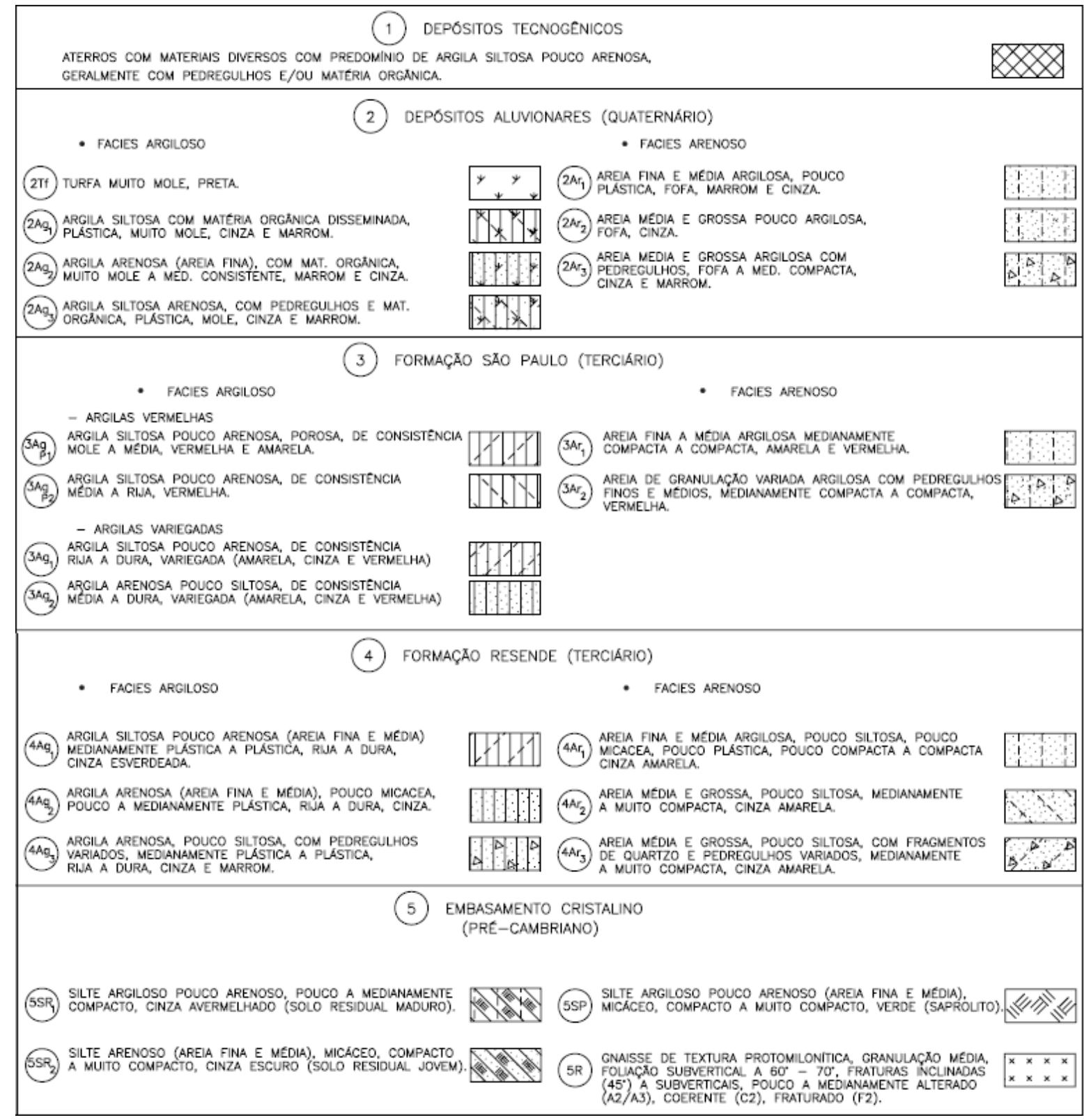

Figura 8 - Sistema de classificação de unidades geológico-geotécnicas utilizado pelo Metrô. Fonte: CMSP (2011).

Os valores dos parâmetros geotécnicos para os aterros e depósitos aluviais estão apresentados na Figura 9, para os depósitos da Formação São Paulo na Figura 10 e para os depósitos da Formação Resende na Figura 11. A Figura 12 apresenta os parâmetros geotécnicos para cálculo a partir das faixas de valores de Nspt para cada camada. Estas informações foram gentilmente cedidas pelo Metrô e constam do memorial justificativo dos parâmetros geotécnicos da Linha 4 - Amarela (CMSP, 1994). 


\begin{tabular}{|c|c|c|c|c|c|c|c|}
\hline $\begin{array}{l}\text { Propriedades } \\
\text { (Unidades) }\end{array}$ & $\begin{array}{c}1 \\
\text { Aterro }\end{array}$ & $2 \mathrm{Tf}$ & 2AgI & $2 \mathrm{Ag}_{2}$ & $2 \mathrm{Ag}^{3}$ & 2Ar1 & $2 \mathrm{Ar} 2 \in 2 \mathrm{Ar} 3$ \\
\hline Descriglo & $\begin{array}{l}\text { Argila sitto } \\
\text { arenosa }\end{array}$ & $\begin{array}{l}\text { Turfa } \\
\text { muito } \\
\text { mole }\end{array}$ & $\begin{array}{l}\text { Argila } \\
\text { siltosa } \\
\text { com } \\
\text { matèria } \\
\text { organica }\end{array}$ & $\begin{array}{c}\text { Argila } \\
\text { arenosa } \\
\text { com } \\
\text { matéria } \\
\text { orginica }\end{array}$ & $\begin{array}{c}\text { Argila } \\
\text { areno- } \\
\text { siltosa } \\
\text { com } \\
\text { materis } \\
\text { orginica }\end{array}$ & $\begin{array}{l}\text { Areia } \\
\text { fins } \\
\text { argilosa }\end{array}$ & $\begin{array}{l}\text { Areia média } \\
\text { e groses, } \\
\text { argiloss } e \\
\text { com } \\
\text { pedregulhos }\end{array}$ \\
\hline SPT & $2 \times 7$ & 0 & 0.4 & 0.4 & 0.4 & 1 a9 & $2 \times 13$ \\
\hline$\gamma\left(\mathrm{kN} / \mathrm{m}^{3}\right)$ & 16 & 14 & 16 & 16 & 16 & 17 & 17 \\
\hline$\phi^{\circ}\left({ }^{\circ}\right)$ & 20 & 15 & 20 & 20 & 20 & 28 & 28 \\
\hline $\mathrm{c}^{*}(\mathrm{RPa})$ & 10 & 5 & 8 & 8 & 8 & 5 & 5 \\
\hline $\mathrm{Ce} /\left(1+c_{0}\right)$ & 0,07 & 0.3 & 0,15 & 0,10 & 0,08 & 0.05 & 0,05 \\
\hline$K(\mathrm{~cm} / \mathrm{s})$ & $10^{-5}$ & $10^{-4}$ & $10^{-3}$ & $10^{-5}$ & $10^{-3}$ & $10^{-3}$ & $5 x ! 0^{-3}$ \\
\hline $\mathrm{E}_{0}\left(\mathrm{MP} \mathrm{P}_{0}\right)$ & $8 \times 28$ & 1 & $.1 \times 16$ & 1 a 16 & 1 a 16 & $4 a 36$ & $8 \times 52$ \\
\hline $\mathrm{Cv}\left(\mathrm{cm}^{2 / 10)}\right.$ & & $10^{-3}$ & $5 \times 10^{-3}$ & $5 \times 10^{-3}$ & $5 \times 10^{-3}$ & & \\
\hline $\mathrm{K}_{0}$ & 0.83 & 0.88 & 0.83 & 0.83 & 0.83 & 0.73 & 0.73 \\
\hline $\begin{array}{l}\text { E cstático }=2 \\
\text { Poisson }=0.15\end{array}$ & $\begin{array}{l}\text { ENS } \\
0.25\end{array}$ & & & & & & \\
\hline
\end{tabular}

Figura 9 - Parâmetros geotécnicos para aterros e aluviões. Fonte: CMSP (1994).

\begin{tabular}{|c|c|c|c|c|c|c|}
\hline $\begin{array}{l}\text { Propriedades } \\
\text { (Lnidades) }\end{array}$ & $3 \mathrm{Arl}$ & $3 \mathrm{Ar} 2$ & 3 AEP1 & $3 \mathrm{AqP2}$ & 3 AgI & $3 \mathrm{Ag}$ \\
\hline Descriça & $\begin{array}{l}\text { Areis Fina } \\
\text { a Media } \\
\text { e } \\
\text { Argiloss }\end{array}$ & $\begin{array}{l}\text { Areia Médis, } \\
\text { Argilosa } \\
\text { corn } \\
\text { pedregulhos }\end{array}$ & $\begin{array}{c}\text { Argila } \\
\text { Porosa } \\
\text { Vermeha. }\end{array}$ & $\begin{array}{c}\text { Afgila } \\
\text { Vermeitha } \\
\text { Rijs }\end{array}$ & $\begin{array}{l}\text { Argila Sillosa } \\
\text { Variegads } \\
\text { Rija e } \\
\text { Dura } \\
\end{array}$ & $\begin{array}{c}\text { Argila Arenoss } \\
\text { Variegada } \\
\text { Iledia e } \\
\text { Dura }\end{array}$ \\
\hline SPTiprof $(m)$ & \multicolumn{4}{|c|}{$\mathrm{SPT}=\operatorname{prof}(\mathrm{m}) / 2$} & & \\
\hline$\gamma\left(\mathrm{KN} / \mathrm{m}^{3}\right)$ & 19,0 & 19,0 & $14.5 \mathrm{~s} 16.0$ & $16.0 \mathrm{a} 18,0$ & $17,0 \Omega 20,0$ & $17,0,20,0$ \\
\hline $\mathrm{e}$ & 0.85 & 0,85 & $1,20 \mathrm{a} \quad 1,80$ & $1,00 \mathrm{a} 1,40$ & $0.50 \times 1.20$ & $0,50 \mathrm{a} 1,20$ \\
\hline$K(\mathrm{~cm} / \mathrm{s})$ & $10^{-3}$ & $10^{-3}$ & $5 \times 10^{-4}$ & $5 \times 10^{-4}$ & $10^{-4}$ & $5 \times 10^{-4}$ \\
\hline $\mathrm{C}_{\mathrm{v}\left(\mathrm{cm}^{2} / \mathrm{s}\right)}$ & - & - & $5,0 \times 10^{-2}$ & $5,0 \times 102$ & $5.0 \times 102$ & $5.0 \times 10^{-2}$ \\
\hline $\mathrm{Ce} /\left(1+\varepsilon_{0}\right)$ & - & $\overline{-}$ & 0,016 A 0,023 & $0,023,0,029$ & $0,008,0,022$ & $0,008 \_0,022$ \\
\hline $\mathrm{Cc} /\left(1+\epsilon_{0}\right)$ & - & - & $0,16: 0,23$ & $0,23 \mathrm{a} 0,29$ & $0.08 \mathrm{a} 0.22$ & $0,08 \leq 0.22$ \\
\hline$e^{\prime}(\mathbf{t P a})$ & 3 & 1 & 20 & 40 & 758100 & $40 \times 100$ \\
\hline$\phi(0)$ & 30.35 & 30.35 & 27 & 25 & $22 \Delta 21$ & $24 \times 21$ \\
\hline $\mathrm{pt}^{\prime}\left(\mathbf{E} \mathbf{P}_{\mathbf{i}}\right)$ & 400,1000 & 400.1000 & 200 & 400 & $750 \times 1000$ & 400,1000 \\
\hline OCR & $3,0,1,5$ & $3,0 \mathrm{a} 1,5$ & $2,0 \mathrm{a} 1,1$ & $2.0 \mathrm{a} 1.5$ & $3,0,2,5$ & $3,3 \approx 2,2$ \\
\hline$K_{0}$ & $0,87 \approx 0,54$ & $0,87,0,54$ & 0,60 & 0.60 & $0,80 \mathrm{~s} 1,00$ & $0,80 \mathrm{a} 1,00$ \\
\hline$E_{0}(\mathrm{AP})$ & $50 a 200$ & 502175 & $10 \mathrm{~s} 30$ & 35.80 & $50 a 200$ & 30.175 \\
\hline $\mathbf{R f}$ & 0.75 & 0,73 & 0,75 & 0,75 & 0,75 & 0,75 \\
\hline \multicolumn{7}{|c|}{ Eestitico $=2 \times E_{0} / 5$} \\
\hline
\end{tabular}

Figura 10 - Parâmetros geotécnicos para a Formação São Paulo. Fonte: CMSP (1994). 


\begin{tabular}{|c|c|c|c|c|c|c|}
\hline $\begin{array}{l}\text { Propriedades } \\
\text { (Lividadess) }\end{array}$ & 4 Ar1 & $4 \mathrm{Ar}^{2}$ & $4 \mathrm{Ar3}$ & 4 Agl & $4 \mathrm{Ag} 2$ & 4 tg3 \\
\hline Descricilo & $\begin{array}{l}\text { Areis } \\
\text { Fina. } \\
\text { Mádia c } \\
\text { Argiosa } \\
\end{array}$ & $\begin{array}{l}\text { Areia } \\
\text { Arédia } \\
\text { Orussa e } \\
\text { Argilosa }\end{array}$ & $\begin{array}{l}\text { Areia } \\
\text { Média e } \\
\text { Grossa }\end{array}$ & $\begin{array}{l}\text { Argila } \\
\text { Sirtosa }\end{array}$ & $\begin{array}{l}\text { Argila } \\
\text { Arenosa }\end{array}$ & $\begin{array}{l}\text { Argils } \\
\text { Arenosn } \\
\text { com } \\
\text { Pedregulhos } \\
\end{array}$ \\
\hline SPTiprof (m) & \multicolumn{6}{|c|}{ Minimo: SPT $=$ prof $(m) / 2$} \\
\hline$\gamma\left(\mathbf{k N} / \mathrm{m}^{3}\right)$ & $18,7 \mathrm{a} 20,6$ & 18.7 a 20,6 & $18,7 \mathbf{a ~ 2 0 , 6}$ & $18.8 \mathrm{a} 21.6$ & $18,8 \mathrm{a} 21,6(3,4)$ & $18,8=21,6$ \\
\hline $\mathrm{K}(\mathrm{cen} / \mathrm{s})$ & $5 \times 10^{-3} 39 \times 10^{-3}$ & $2 \times 10^{-2} \times 10^{-4}$ & $9 \times 10^{-3} 35 \times 10^{-2}$ & $10^{-7}$ & $10^{-7}$ & $10^{-7}$ \\
\hline $\mathrm{Cv}\left(\mathrm{cm}^{2} / \mathrm{s}\right)$ & - & - & - & $5 \times 10^{-3}$ & $5 \times 10^{-3}$ & $5 \times 10^{-3}$ \\
\hline $\mathrm{Ce}\left(1+\infty_{0}\right)$ & - & - & - & $0,01: 0.02$ & 0,0 ta 0.02 & $0,01 \mathrm{~s} 0.02$ \\
\hline $\mathrm{Cc}(1+\infty)$ & - & - & - & $0,10 \mathrm{a} 0,20$ & $0,10 \& 0,20$ & $0,10 \times 0,20$ \\
\hline$c^{\prime}\left(\mathbf{E P} \mathbf{P}_{4}\right)$ & 5 & 3 & 1 & $40 s 100$ & 40,100 & 25 \\
\hline$\phi^{\prime}\left({ }^{\circ}\right)$ & 30435 & $30 \mathrm{a} 40$ & 30140 & $24 a 21$ & $24 a 21$ & 27 \\
\hline$p a^{\prime}\left(\mathbf{P}_{0}\right)$ & $400 \mathrm{a} 1000$ & $400 \times 1000$ & $\$ 00.1000$ & $400 \mathrm{a} 1000$ & $400 \mathrm{a} 1000$ & $>360$ \\
\hline$\overline{O C R}$ & $3,3 \mathrm{a} !, 7$ & $3,3 \mathrm{a} 1,7$ & $23,3 \times 1,7$ & $3,3 \mathrm{a} 1.7$ & $3,3 \times 1.7$ & 34 \\
\hline $\mathrm{K}_{0}$ & 0,8 & 0,8 & 0,8 & 0,8 & 0,8 & 0.8 \\
\hline Eo (MPA) & 40.150 & 50.350 & 30.200 & 40.170 & 40.80 & 180,360 \\
\hline $\mathbf{R S}$ & 0.75 & 0,75 & 0,75 & 0,75 & 0.75 & 0.75 \\
\hline \multicolumn{7}{|c|}{ Eestinico $=2 \times \mathrm{Eo} / \mathrm{S}$} \\
\hline
\end{tabular}

Figura 11 - Parâmetros geotécnicos para a Formação Resende. Fonte: CMSP (1994). 


\begin{tabular}{|c|c|c|c|c|c|c|c|}
\hline SOLO & SPT & $\begin{array}{c}\gamma \\
\left(\mathrm{KN} / \mathrm{m}^{3}\right) \\
\end{array}$ & $\begin{array}{c}\mathrm{c}^{\prime} \\
\left(\mathrm{KN} / \mathrm{m}^{2}\right)\end{array}$ & $\begin{array}{c}\phi^{\prime} \\
\text { (graus) }\end{array}$ & $\mathrm{Ko}$ & $\begin{array}{c}\mathrm{Kh} \\
\left(\mathrm{MN} / \mathrm{m}^{3}\right)\end{array}$ & $\begin{array}{c}\mathrm{E} \\
(\mathrm{MPa}) \\
\end{array}$ \\
\hline 1 & $2 a 7$ & 16.0 & 10 & 20 & 0.83 & 4.68 & 7.2 \\
\hline $2 \mathrm{TF}$ & 0 & 14.0 & 5 & 15 & 0.88 & 0.52 & 0.8 \\
\hline $2 \mathrm{Agl}$ & $0 \mathrm{at}$ & 16.0 & 8 & 20 & 0.83 & 2.08 & 3.2 \\
\hline $2 \mathrm{Ag} 2$ & $0 \mathrm{a} 4$ & 16.0 & 8 & 20 & 0,83 & 2.08 & 3.2 \\
\hline $2 \mathrm{Ag} 3$ & $0 \mathrm{a} 4$ & 16.0 & 8 & 20 & 0.83 & 2.08 & 3.2 \\
\hline $2 \mathrm{Arl}$ & 1 a 9 & 17.0 & 5 & 28 & 0.73 & 5.2 & 8.0 \\
\hline $2 \mathrm{Ar} 2$ & 2 a 13 & 17.0 & 5 & 28 & 0.73 & 7.28 & 11.2 \\
\hline $2 \mathrm{Ar} 3$ & 2 a 13 & 17.0 & 5 & 28 & 0.73 & 7.28 & 11.2 \\
\hline \multirow{2}{*}{$3 \mathrm{AgPl}$} & $2 \mathrm{a} 4$ & 15.0 & 20 & 27 & 0.6 & 3.9 & 6 \\
\hline & 5 a 10 & 16.0 & 20 & 27 & 0.6 & 9.75 & 15 \\
\hline \multirow[t]{2}{*}{$3 \mathrm{AgP2}$} & $5 \times 10$ & 16.5 & 40 & 25 & 0.6 & 9.75 & 15 \\
\hline & $>10$ & 18.0 & 40 & 25 & 0.6 & 19.5 & 30 \\
\hline \multirow[t]{7}{*}{$3 \mathrm{Ag} 1$} & 305 & 17.0 & 25 & 27 & 0.90 & 5.2 & 8 \\
\hline & 5 a 8 & 18.0 & 30 & 25 & 0.90 & 9.75 & 15 \\
\hline & 8 a 12 & 19.0 & 40 & 24 & 0.90 & 13.0 & 20 \\
\hline & 12 a 18 & 20.0 & 50 & 23 & 0.90 & 19.5 & 30 \\
\hline & 18 a 25 & 20.0 & 75 & 22 & 0.80 & 29.25 & 45 \\
\hline & 25 a 40 & 20.0 & 100 & 21 & 0.80 & 42.25 & 65 \\
\hline & $>40$ & 20.0 & 150 & 20 & 0.80 & 65 & 100 \\
\hline \multirow[t]{7}{*}{$3 \mathrm{Ag} 2$} & 3 a 5 & 17.0 & 25 & 27 & 0.90 & 5.2 & 8 \\
\hline & $5 \mathrm{a} 8$ & 18.0 & 30. & 25 & 0.90 & 9.75 & 15 \\
\hline & 8 a 12 & 19.0 & 40 & 24 & 0.90 & 13.0 & 20 \\
\hline & 12 a 18 & 20.0 & 50 & 23 & 0.90 & 19.5 & 30 \\
\hline & 18 a 25 & 20.0 & 75 & 22 & 0.80 & 29.25 & 45 \\
\hline & 25 a 40 & 20.0 & 100 & 21 & 0.80 & 42.25 & 65 \\
\hline & $>40$ & 20.0 & 150 & 20 & 0.80 & 65 & 100 \\
\hline \multirow[t]{3}{*}{$3 \mathrm{Arl}$} & $5 \times 10$ & 19.0 & 3 & 30 & 0.80 & 6.5 & 10 \\
\hline & 10 a 20 & 19.0 & 3 & 32 & 0.80 & 19.5 & 30 \\
\hline & $>20$ & 19.0 & 3 & 35 & 0.80 & 32.5 & 50 \\
\hline \multirow[t]{3}{*}{$3 \mathrm{Ar} 2$} & 5 a 10 & 19.0 & 3 & 30 & 0.80 & 6.5 & 10 \\
\hline & 10 a 20 & 19.0 & 3 & 32 & 0.80 & 19.5 & 30 \\
\hline & $>20$ & 19.0 & 3 & 35 & 0.80 & 32.5 & 50 \\
\hline \multirow[t]{7}{*}{$4 \mathrm{AgI}$} & 3 a 5 & 19.0 & 25 & 27 & 0.80 & 5.2 & 8 \\
\hline & 5 a 8 & 19.5 & 30 & 25 & 0.80 & 9.75 & 15 \\
\hline & 8 a 12 & 20.0 & 40 & 24 & 0.80 & 13 & 20 \\
\hline & 12 a 18 & 20.5 & 50 & 23 & $0.80^{\circ}$ & 19.5 & 30 \\
\hline & 18 a 25 & 21 & 75 & 22 & 0.80 & 29.25 & 45 \\
\hline & 25 a 40 & 21.5 & 100 & 21 & 0.80 & 42.25 & 65 \\
\hline & $>40$ & 21.5 & 150 & 20 & 0.80 & 65 & 100 \\
\hline \multirow[t]{7}{*}{$4 \mathrm{Ag} 2$} & 3 a 5 & 19.0 & 25 & 27. & $0.80^{\circ}$ & 5.2 & 8 \\
\hline & 5 a 8 & 19.5 & 30 & 25 & 0.80 & 9.75 & 15 \\
\hline & 8 a 12 & 20.0 & 40 & 24 & 0.80 & 13 & 20 \\
\hline & 12 a 18 & 20.5 & 50 & 23 & 0.80 & 19.5 & 30 \\
\hline & 18 a 25 & 21 & 75 & 22 & 0.80 & 29.25 & 45 \\
\hline & $25 \mathrm{a}+0$ & 21.5 & 100 & 21 & 0,80 & $\$ 2.25^{\circ}$ & 65 \\
\hline & $>40$ & 21.5 & 150 & 20 & 0.80 & 65 & 100 \\
\hline \multirow[t]{7}{*}{$4 \mathrm{Ag}^{3}$} & 3 a 5 & 19.0 & 25 & 27 & 0.80 & 5.2 & 8 \\
\hline & 5 a 8 & 19.5 & 30 & 25 & 0.80 & 9.75 & 15 \\
\hline & 8 a 12 & 20.0 & to & 24 & 0.80 & 13 & 20 \\
\hline & 12 a 18 & 20.5 & 50 & 23 & 0.80 & 19.5 & 30 \\
\hline & 18 a 25 & 21 & 75 & 22 & 0.80 & 29.25 & 45 \\
\hline & 25 a 40 & 21.5 & 100 & 21 & 0.80 & 42.25 & 65 \\
\hline & $>40$ & 21.5 & 150 & 20 & 0.80 & 65 & 100 \\
\hline \multirow[t]{3}{*}{$4 \mathrm{Arl}$} & 5 a 10 & 19.0 & 5 & 30 & 0.80 & 9.75 & 15 \\
\hline & 10 a 20 & 20 & 5 & 32 & 0.80 & 19.5 & 30 \\
\hline & $>20$ & 20.6 & 5 & 35 & 0.80 & 32.5 & 50 \\
\hline \multirow[t]{3}{*}{$4 \mathrm{Ar} 2$} & 5 a 10 & 19.0 & 5 & 30 & 0.80 & 9.75 & 15 \\
\hline & 10 a 20 & 20 & 5 & 32 & 0.80 & 19.5 & 30 \\
\hline & $>20$ & 20.6 & 5 & 35 & 0.80 & 32.5 & 50 \\
\hline \multirow[t]{3}{*}{$4 \mathrm{Ar} 3$} & 5 a 10 & 19.0 & 5 & 30 & 0.80 & 9.75 & 15 \\
\hline & 10 a 20 & 20 & 5 & 32 & 0.80 & 19.5 & 30 \\
\hline & $>20$ & 20.6 & 5 & 35 & 0.80 & 32.5 & 50 \\
\hline
\end{tabular}

Figura 12 - Parâmetros geotécnicos para cálculo na Bacia de São Paulo. Fonte: CMSP (1994). 


\section{RESULTADOS OBTIDOS}

Neste estudo foram analisadas as amostras e ensaios de 230 sondagens mistas e à percussão executadas em um trecho da Linha 17 - Ouro do Metrô e elaboradas três seções geológicas ao longo das avenidas Washington Luís (Seção A), Jornalista Roberto Marinho (Seção B), e das Nações Unidas (Seção C), conforme indicado na Figura 13 e nos desenhos em anexo.

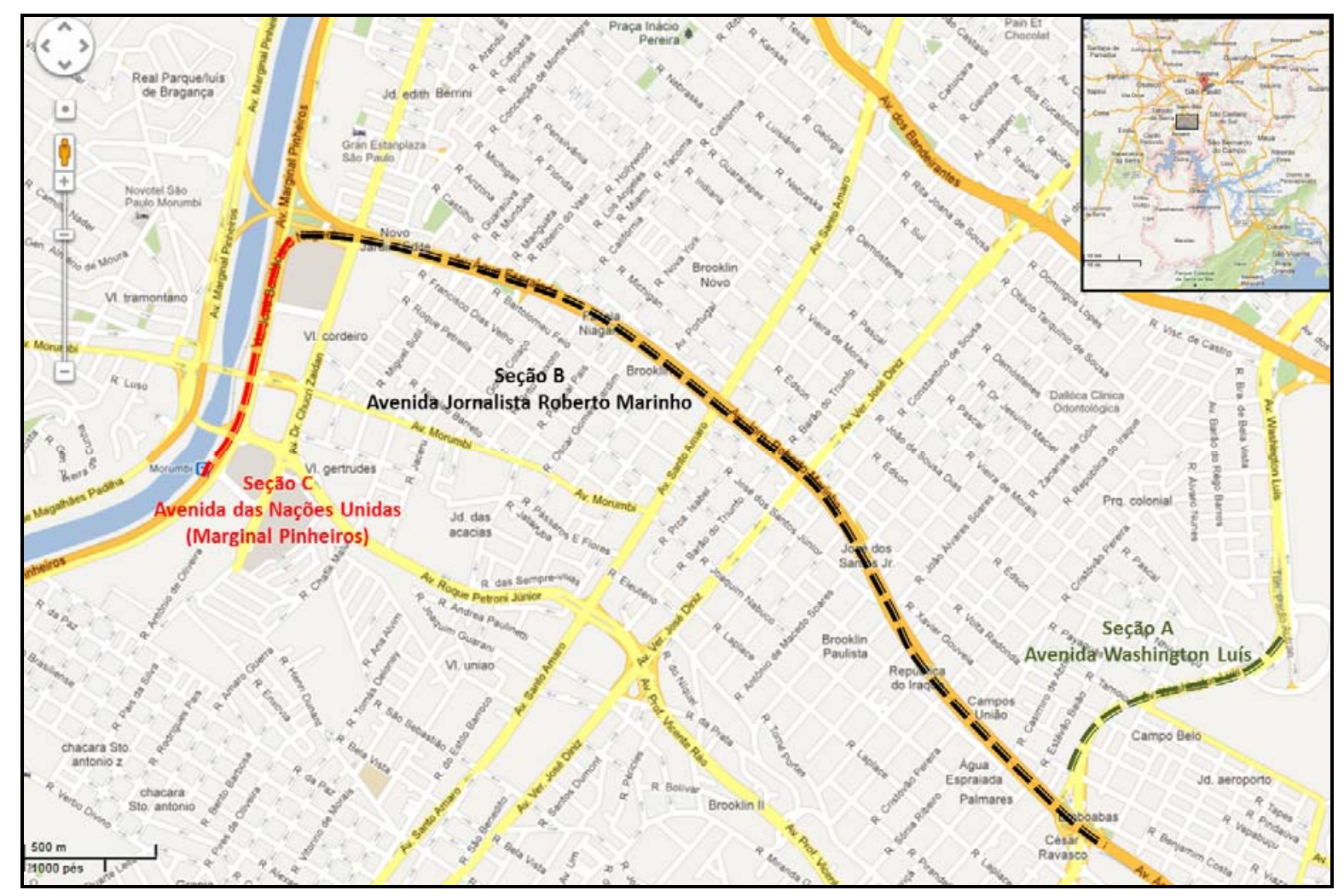

Figura 13 - Localização das seções geológicas em parte da Linha 17 - Ouro do Metrô ao longo das Washington Luís (Seção A), Jornalista Roberto Marinho (Seção B), e das Nações Unidas (Seção C), no quadro do canto superior direito o detalhe da localização do município de São Paulo. Fonte do mapabase: GoogleMaps ${ }^{\circledR}, 2013$.

\subsection{ANÁLISE DAS SONDAGENS}

As sondagens utilizadas neste estudo foram executadas de acordo com as diretrizes da ABGE (Associação Brasileira de Geologia de Engenharia, 1999) e da norma NBR-6484 da Associação Brasileira de Normas Técnicas (ABNT). 
As sondagens a percussão e mistas foram executadas com ensaios SPT (standard penetration test) a cada metro no trecho em solo, sedimento ou rocha sedimentar. Este ensaio utiliza um amostrador padronizado que é cravado em decorrência da queda de um martelo de $65 \mathrm{~kg}$ da altura de $75 \mathrm{~cm}$, anotando-se o número de golpes necessários para cravar $45 \mathrm{~cm}$ no subsolo.

O valor de Nspt adotado corresponde à somatória do número de golpes necessário para a cravação dos últimos $30 \mathrm{~cm}$ de ensaio, sendo considerado impenetrável ao SPT o nível a partir do qual o Nspt é igual ou superior a 50 golpes. A amostragem do subsolo neste trecho corresponde à coleta do material contido no bico do amostrador do ensaio, sendo colhida uma amostra de aproximadamente 5 a $6 \mathrm{~cm}$ a cada metro perfurado.

Este tipo de sondagem é o instrumento de investigação geotécnica mais utilizado no Brasil, principalmente para a avaliação da capacidade de carga do solo para fundações. Mesmo com a padronização definida na norma, há vários fatores que influenciam na precisão do ensaio SPT, sendo que a energia transmitida do martelo para o maciço depende principalmente dos seguintes fatores: comprimento da composição de hastes (Aoki \& Cintra, 2000), tamanho da cabeça de bater, tipo de roldana (móvel ou fixa), forma e tipo do coxim, tipo de martelo, idade e desgaste dos equipamentos (Belicanta \& Cintra, 1998), além da própria execução em campo pelas equipes de sondagem. Para minimizar estas interferências e garantir a qualidade dos serviços, as perfurações foram acompanhadas em campo por técnicos responsáveis pela fiscalização das equipes pelo consórcio responsável pelas obras.

Todas as amostras das sondagens utilizadas neste estudo foram analisadas com o emprego da classificação tátil-visual. Nesta classificação foram observadas litologia, granulometria dos grãos, presença de fragmentos, minerais visíveis a olho nu, matéria orgânica, cor, plasticidade, compacidade e consistência (Tabela 1), entre outros. A Figura 14 apresenta a sondagem SP-0512 como exemplo da classificação tátil-visual das amostras. 


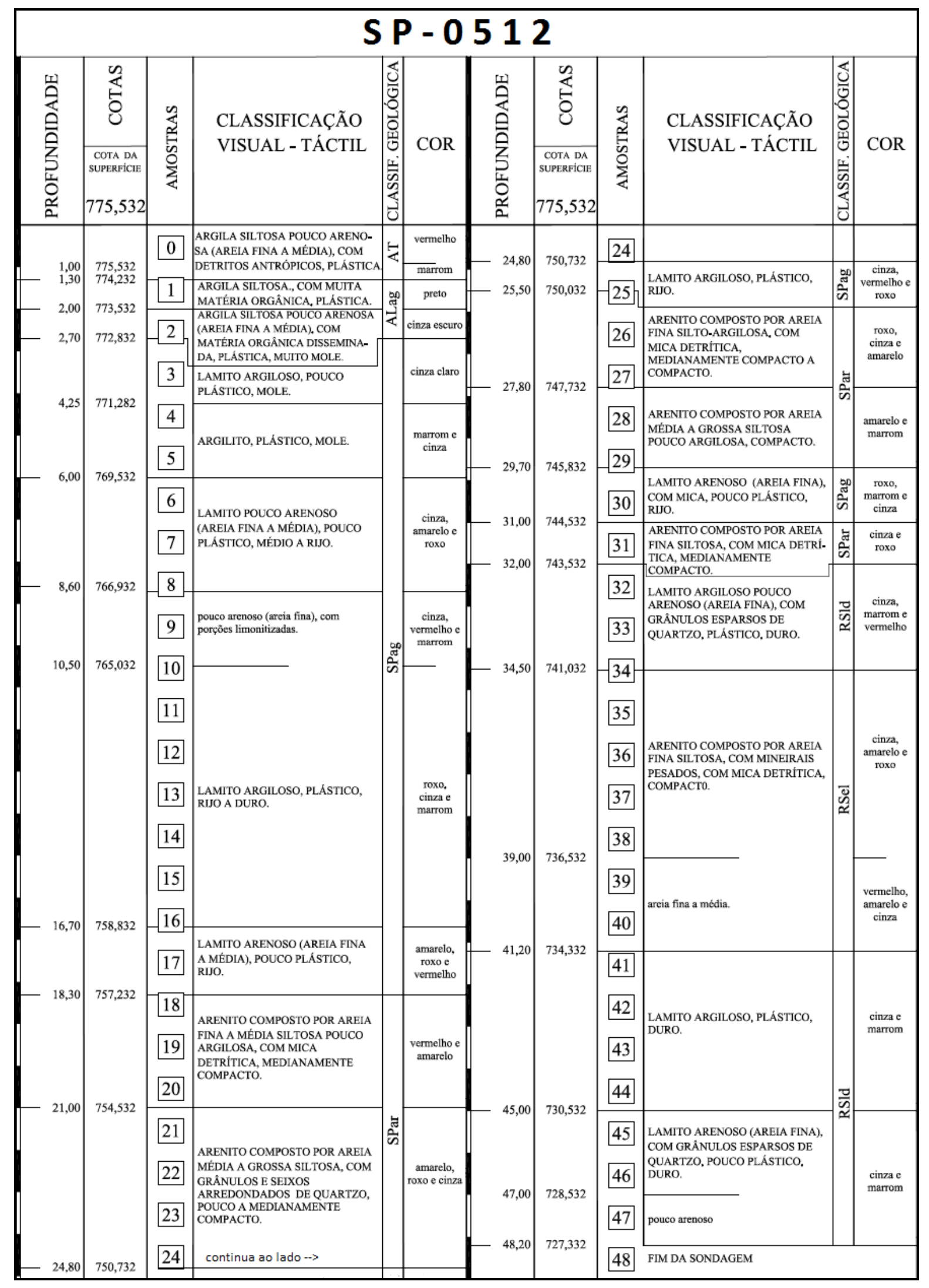

Figura 14 - Classificação tátil-visual da sondagem SP-0512 localizada na Avenida Washington Luís. 
Tabela 1 - Tabela de classificação de compacidade ou consistência de acordo com o valor de Nspt. Fonte: Modificado de NBR-6484/2010.

\begin{tabular}{|c|l|l|}
\hline Granulometria & Compacidade ou Consistência & \multicolumn{1}{|c|}{ Nspt } \\
\hline \multirow{4}{*}{$\begin{array}{c}\text { Areias ou Siltes } \\
\text { arenosos }\end{array}$} & Fofa & $\leq 4$ \\
\cline { 2 - 3 } & Pouco compacta & $5-8$ \\
\cline { 2 - 3 } & Medianamente compacta & $9-18$ \\
\cline { 2 - 3 } & Compacta & $19-39$ \\
\cline { 2 - 3 } & Muito Compacta & $\geq 40$ \\
\hline \multirow{4}{*}{$\begin{array}{c}\text { Argilas ou Siltes } \\
\text { argilosos }\end{array}$} & Muito mole & $\leq 2$ \\
\cline { 2 - 3 } & Mole & $3-5$ \\
\cline { 2 - 3 } & Média & $6-10$ \\
\cline { 2 - 3 } & Rija & $11-19$ \\
\cline { 2 - 3 } & Dura & $20-49$ \\
\cline { 2 - 3 } & Muito dura & $\geq 50$ \\
\hline
\end{tabular}

Para os trechos em rocha, observou-se a alteração, coerência, fraturas, recuperação das manobras (em porcentagem) e RQD (rock quality designation), conforme especificado a seguir.

Tabela 2 - Graus de alteração e de coerência da rocha. Fonte: Modificado de Serra Júnior \& Ojima, 1998.

\begin{tabular}{|l|l|l|l|}
\hline \multicolumn{2}{|c|}{ GRAU DE ALTERAÇÃO } & \multicolumn{2}{c|}{ GRAU DE COERÊNCIA } \\
\hline A1 & SÃ & C1 & MUITO COERENTE \\
\hline A2 & POUCO ALTERADA & C2 & COERENTE \\
\hline A3 & MEDIANAMENTE ALTERADA & C3 & MEDIANAMENTE COERENTE \\
\hline A4 & MUITO A EXTREMAMENTE ALTERADA & C4 & POUCO COERENTE \\
\hline
\end{tabular}

Tabela 3 - Classes de fraturamento da rocha. Fonte: Modificado de Serra Júnior \& Ojima, 1998.

\begin{tabular}{|c|c|l|}
\hline GRAU DE FRATURAMENTO & QUANTIDADE DE FRATURAS POR METRO & \multicolumn{1}{|c|}{ DESCRIÇÃO } \\
\hline F1 & 0 a 1 & POUCO FRATURADO \\
\hline F2 & 2 a 5 & FRATURADO \\
\hline F3 & 6 a 10 & MUITO FRATURADO \\
\hline F4 & 11 a 20 & EXTREMAMENTE FRATURADO \\
\hline F5 & Mais de 20 & FRAGMENTADO \\
\hline
\end{tabular}

O RQD (rock quality designation) é um parâmetro proposto por Deere et al. (1967) ainda muito utilizado na geotecnia, principalmente na classificação de 
sondagens, para determinar a qualidade do maciço rochoso com o emprego da expressão:

$R Q D=(\Sigma p / n) \times 100$

Sendo:

$\mathrm{p}$ = número de peças maiores que $10 \mathrm{~cm}$;

$\mathrm{n}=$ comprimento da manobra de avanço da perfuração da sondagem.

\subsection{DEFINIÇÃO DAS UNIDADES GEOLÓGICO-GEOTÉCNICAS}

Após a análise das amostras de sondagem, avaliação dos resultados dos ensaios SPT e comparação com as informações geológicas e geotécnicas obtidas da literatura, foram definidas as unidades geológico-geotécnicas presentes neste estudo, sendo, do topo para a base: aterro, aluvião, rochas sedimentares da Formação São Paulo, rochas sedimentares da Formação Resende e embasamento, conforme detalhados a seguir.

\subsubsection{Aterro}

Os aterros (AT) são depósitos tecnogênicos de composição variada, predominando argilas siltosas a arenosas, plásticas a pouco plásticas, de cor marrom ou vermelha, com valores variáveis de Nspt. Localmente podem apresentar matéria orgânica, detritos antrópicos (como plástico ou entulho) ou fragmentos de rocha, sendo que em alguns locais são constituídos essencialmente por estes fragmentos.

\subsubsection{Aluvião}

Os aluviões foram divididos em duas subunidades principais: ALag e Alar sendo: 
ALag - São depósitos fluviais meandrantes de planície de inundação ou meandros abandonados, compostos por argilas e lamas ricas em matéria orgânica, plásticos a muito plásticos, de cor preta ou cinza escura, de consistência mole a muito mole. Correspondem às camadas descritas no meio geotécnico como "argila orgânica".

Alar - São depósitos fluviais de canais meandrantes, compostos por areias e cascalhos, podendo conter matéria orgânica e mica detrítica, de cor amarelo claro ou cinza escuro, fofo a pouco compacto, podendo chegar a muito compacto nas camadas ricas em cascalho.

\subsubsection{Formação São Paulo}

As rochas sedimentares da Formação São Paulo foram divididas em três subunidades principais: SPal, SPag e SPar, sendo:

Spal - Corresponde a camada superficial alterada, composta por lamitos argilosos, plásticos a pouco plásticos, de cor vermelha ou vermelha e amarela, com valores predominantemente baixos de $\mathrm{Nspt}$, geralmente abaixo de 5 próximo ao topo da camada e até 11 próximo a base. Correspondem às camadas descritas no meio geotécnico como "argila vermelha" ou "argila porosa".

SPag - São depósitos fluviais meandrantes de planície de inundação ou meandros abandonados, compostos por argilitos e lamitos argilosos, plásticos, apresentando geralmente três ou mais cores, como roxo, cinza, vermelha e amarela, de consistência mole a dura, podendo conter porções limonitizadas. Correspondem às camadas descritas no meio geotécnico como "argila variegada".

SPar - São depósitos fluviais de canais meandrantes ou de rompimento de diques marginais, compostos por arenitos e conglomerados, podendo conter mica detrítica, de cor amarelo claro, roxo, cinza ou vermelho, predominantemente pouco compacto a compacto, podendo chegar a muito compacto nas camadas ricas em cascalho. Estes depósitos tendem a apresentar baixa coesão e alta permeabilidade. 


\subsubsection{Formação Resende}

As rochas sedimentares da Formação Resende foram divididas em três subunidades principais: RSIp, RSId e RSel, sendo:

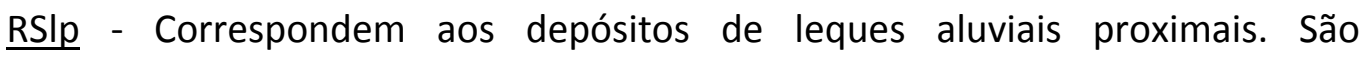
compostos por brechas e diamictitos com matriz predominantemente lamítica, caracterizados pela baixa seleção e presença de fragmentos de rochas do embasamento, podendo conter também mica detrítica e porções muito cimentadas e coesas, de cor cinza esverdeada, cinza, marrom e vermelho, de consistência geralmente dura a muito dura.

$\underline{\text { RSId }}$ - Correspondem aos depósitos de leques aluviais medianos a distais. São compostos por lamitos argilosos a arenosos e argilitos, podendo conter grânulos esparsos de quartzo e mica detrítica, plásticos, de cor cinza esverdeada ou cinza, marrom e vermelho, de coesão elevada e de consistência predominantemente dura. Estas camadas são descritas no meio geotécnico como "taguá".

RSel - São depósitos fluviais provenientes de canais de rios entrelaçados, compostos por arenitos e conglomerados, podendo conter mica detrítica, de cor amarelo claro ou cinza, predominantemente compacto a muito compacto.

\subsubsection{Embasamento}

O embasamento neste trecho corresponde ao Complexo Embu. A subdivisão desta unidade foi feita de acordo com o estudo de Vaz (1996), que estabeleceu os horizontes de alteração para regiões tropicais compatibilizando com os aspectos geotécnicos esperados para cada horizonte. Desta forma, esta unidade apresenta quatro subunidades: EMs1, EMs2, EMr3 e EMr1/2, sendo:

EMs1 - Corresponde ao horizonte de maior alteração intempérica do embasamento ou solo eluvial. É constituído por siltes argilosos a arenosos de cor vermelho claro, cinza ou marrom claro, de consistência mole a média ou fofa a pouco 
compacta. Este horizonte também é descrito no meio geotécnico como "solo residual maduro".

EMs2 - Corresponde ao solo de alteração de rocha. É constituído predominantemente por siltes arenosos, micáceos, podendo conter fragmentos de rocha, de cor cinza, castanho e branco, medianamente compacto a compacto. Este horizonte também é denominado no meio geotécnico como "solo residual jovem".

$\underline{\mathrm{EMr} 3}$ - Corresponde à rocha alterada mole. É constituído predominantemente por biotita gnaisse muito alterado com porções de silte arenoso, micáceos com fragmentos de rocha, de cor cinza, castanho e branco, muito compacto Este horizonte também é descrito no meio geotécnico como "saprolito".

EMr1/2 - Corresponde a rocha sã ou rocha alterada dura. É constituído predominantemente por biotita gnaisse composto predominantemente de feldspato, quartzo e biotita, com foliação inclinada a subvertical, de cor cinza e branco. Pode conter localmente veios de quartzo e pegmatito.

Na Figura 15 são ilustradas cada uma destas unidades, conforme amostrado pelas sondagens utilizadas neste estudo. 


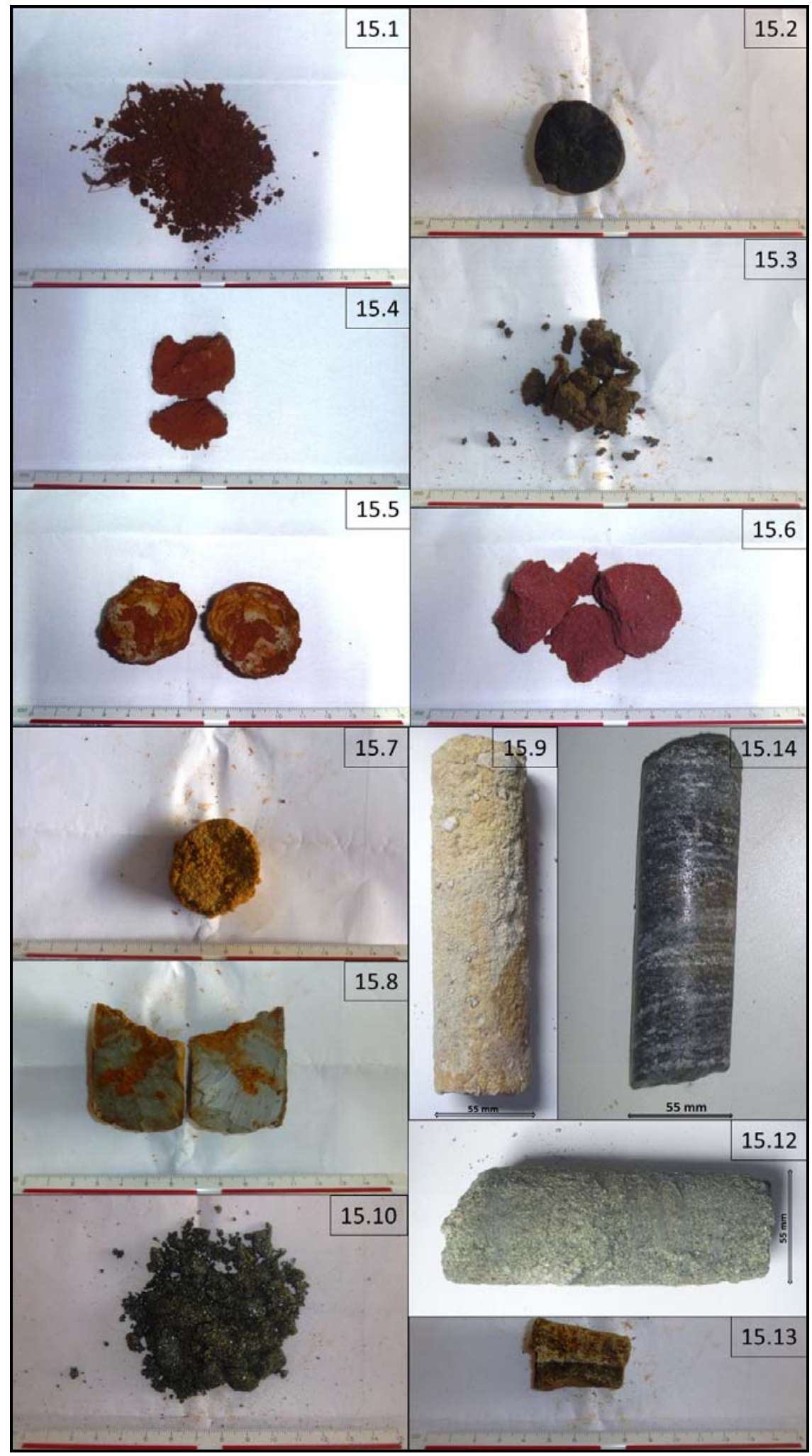

Figura 15 - Fotografias das amostras de sondagens. 15.1 - Aterro (AT), 15.2 Aluvião (ALag), 15.3 Aluvião (ALar), 15.4 Formação São Paulo (SPal), 15.5 Formação São Paulo (SPag), 15.6 Formação São Paulo (SPar), 15.7 Formação Resende (RSel), 15.8 Formação Resende (RSId), 15.9 Formação Resende (RSIp), 15.10 Embasamento (EMs1), 15.11 Embasamento (EMs2), 15.12 Embasamento (EMr3) e 15.13 Embasamento (EMr1/2). 


\subsection{CORRELAÇÃO DOS PERFIS DE SONDAGENS E ELABORAÇÃO DE SEÇÕES GEOLÓGICO-GEOTÉCNICAS}

As sondagens utilizadas foram executadas com o objetivo de investigar as condições do subsolo e projetar as fundações do Monotrilho da Linha 17 - Ouro do Metrô de São Paulo. Foram realizadas, no mínimo, uma sondagem por apoio, com espaçamento médio de $30 \mathrm{~m}$ entre as sondagens, interceptando os três grandes compartimentos geológicos existentes na Região Metropolitana de São Paulo - o embasamento pré-cambriano, as rochas sedimentares paleógenas da Bacia de São Paulo e as coberturas quaternárias.

Neste estudo foram elaboradas três seções geológico-geotécnicas ao longo das avenidas Washington Luís (Seção A), Jornalista Roberto Marinho (Seção B) e das Nações Unidas (Seção C), conforme indicado na Figura 13 e nos desenhos em anexo.

\subsubsection{Seção A}

Na seção A ocorrem aterros, aluviões e rochas sedimentares das formações São Paulo e Resende, conforme indicado na Figura 16.

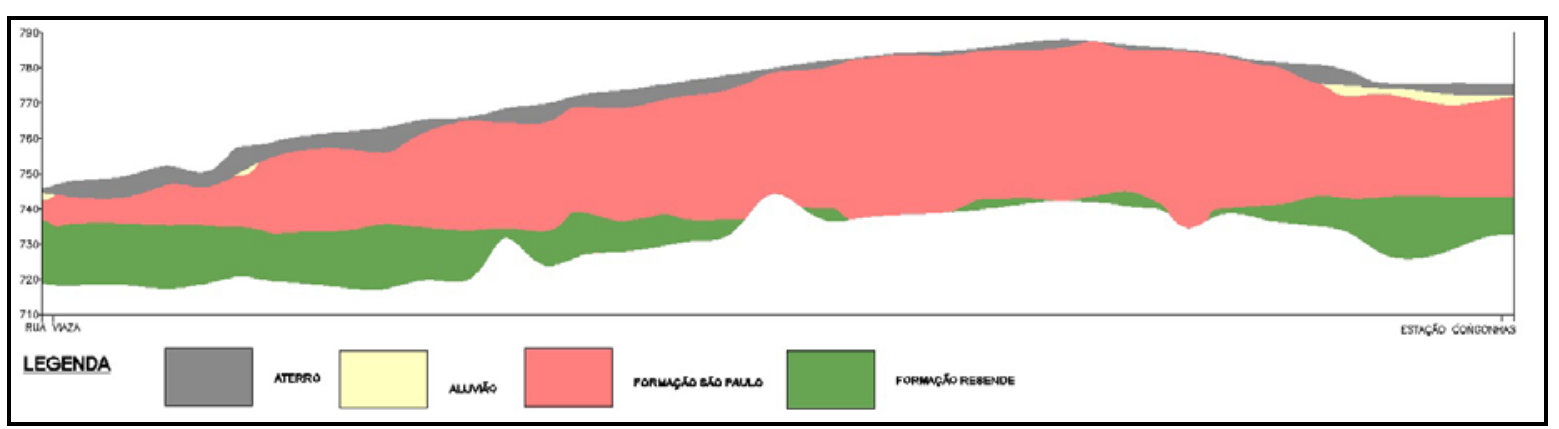

Figura 16 - Seção geológica esquemática A (para seção completa ver anexo).

Os aterros (AT) ou depósitos tecnogênicos recobrem superficialmente a maior parte do trecho, com espessura de até $7 \mathrm{~m}$, sendo menos espessos no trecho entre as ruas Vieira de Morais e Brás de Arzão. 
Os aluviões ocorrem localmente, com valores muito baixos de Nspt (geralmente inferior a 2), espessura de até $3 \mathrm{~m}$ de argilas e lamas ricas em matéria orgânica (ALag) e inferior a $1 \mathrm{~m}$ de areias e cascalhos (Alar) entre a rua Vieira de Moraes e a Estação Congonhas. Apresenta espessura de até $1 \mathrm{~m}$ de ALag na sondagem SM-927 e de até $1 \mathrm{~m}$ de ALal e $1 \mathrm{~m}$ de Alar próximo a rua Vaza.

As rochas sedimentares da Formação São Paulo ocorrem em toda a extensão da seção, sendo que as três subunidades desta formação ocorrem na seção. Os lamitos argilosos alterados (SPal) ocorrem no trecho entre a rua Vieira de Moraes e a sondagem SP-530, com uma ocorrência isolada na sondagem SP-533. Ocorrem predominantemente acima da cota $770 \mathrm{~m}$, com espessura máxima de $13 \mathrm{~m}$ identificada na sondagem SP-518, sempre próxima ao topo da Formação São Paulo. Esta subunidade tende a apresentar valores menores de Nspt (até 5) próxima ao topo e valores maiores (até 14 próxima a base).

Os argilitos e lamitos argilosos provenientes de meandros abandonados e planícies de inundação (ALag) constituem a subunidade predominante na Formação São Paulo. Esta unidade apresenta espessura contínua de até $21 \mathrm{~m}$, identificada na sondagem SP-514, com valores variáveis de Nspt, predominantemente menores próximos ao topo (em torno de 5) e maiores nas demais regiões (em torno de 20).

Os arenitos e conglomerados provenientes de canais de rios meandrantes e rompimento de diques marginais (ALar) ocorrem na forma de lentes alongadas e canais com distribuição aleatória ao longo de toda a seção, com espessura máxima contínua de $16 \mathrm{~m}$ identificada na sondagem SP-538. Apresentam valores mais baixos de Nspt nas lentes mais próximas ao topo, porém as camadas ricas em seixos e cascalho tendem a aumentar o valor do Nspt.

O contato entre as formações São Paulo e Resende ocorre em torno da cota $740 \mathrm{~m}$ (com local mais alto em $745 \mathrm{~m}$ e mais baixo provavelmente na cota $730 \mathrm{~m}$ ). Este contato apresenta-se irregular, com aprofundamentos localizados como observado na 
sondagem SP-516, onde a Formação São Paulo apresenta a espessura máxima nesta seção, superior a $50 \mathrm{~m}$.

As rochas sedimentares da Formação Resende estão representadas pelas subunidades de arenitos e conglomerados de canais de rios entrelaçados (RSel) e lamitos argilosos a arenosos e argilitos de leques aluviais distais (RSId).

A RSId é a subunidade predominante na Formação Resende nesta seção. Ocorre na forma de camadas alongadas, com raras lentes menores envolvidas pela RSel. A espessura máxima contínua identificada é de $10 \mathrm{~m}$ na sondagem SP-540. Apresenta valores predominantemente altos de Nspt, em torno de 35 (com mínimo de 14 e máximo acima de 50).

A RSel apresenta-se como uma lente contínua entre a rua Vaza e rua Padre Leonardo em torno da cota $730 \mathrm{~m}$ e outra entre a rua Vieira de Moraes e a estação Congonhas, com espessura máxima contínua de $8 \mathrm{~m}$ na sondagem 531, além de outras lentes menos significativas. Apresenta valores de Nspt em torno de 25 (com mínimo de 17 e máximo acima de 50).

\subsubsection{Seção B}

$\mathrm{Na}$ seção B ocorrem aterros, aluviões, rochas sedimentares da Formação Resende e embasamento, conforme indicado na Figura 17. 


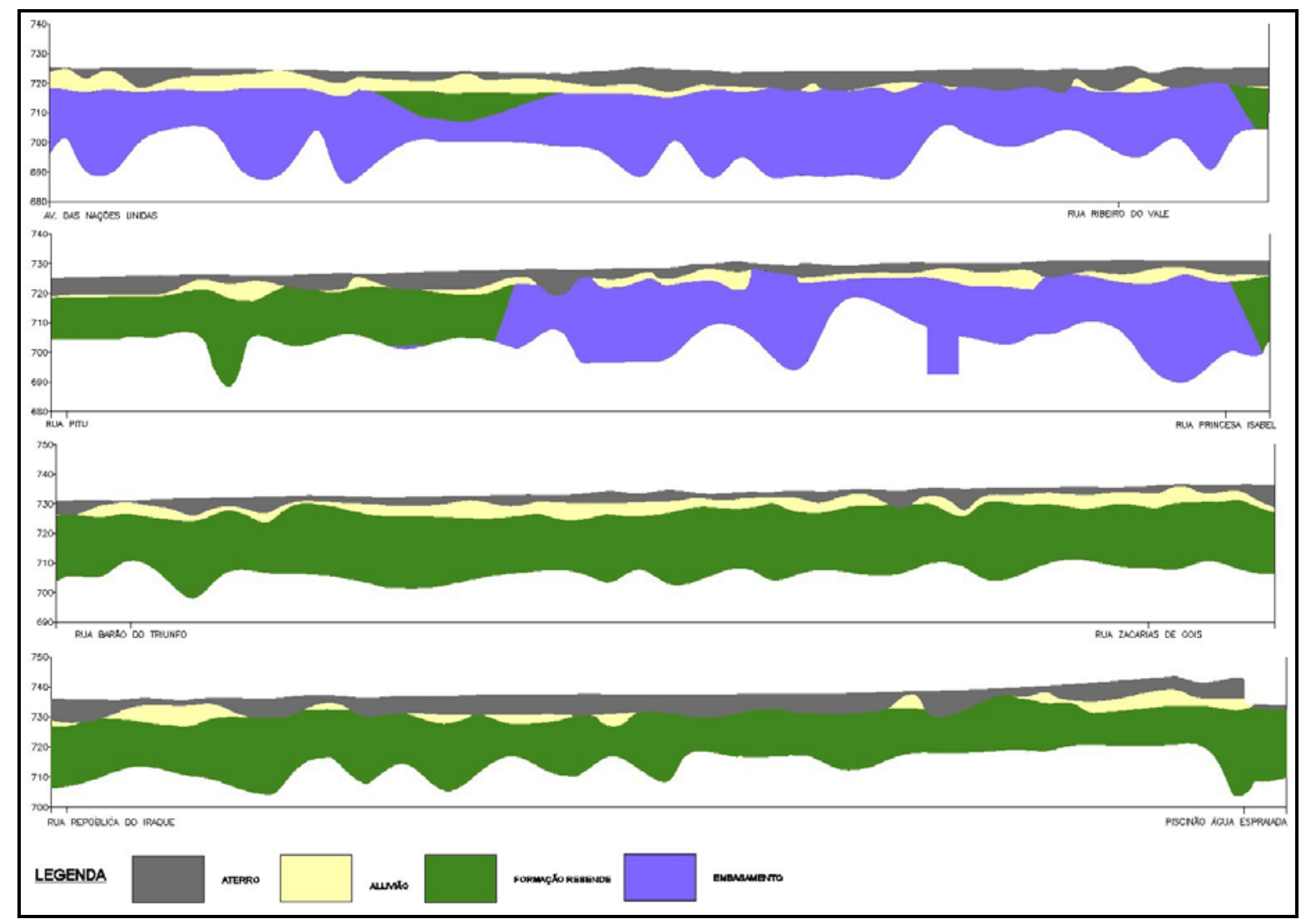

Figura 17 - Seção geológica esquemática B (para seção completa ver anexo).

Os aterros (AT) ou depósitos tecnogênicos recobrem superficialmente todo o trecho, com espessura variável entre 1 a 9m, com valores predominantemente baixos de Nspt. Em porções localizadas próximos ao córrego Água Espraiada são constituídos por fragmentos de rocha ou "rachão, sendo portanto impenetráveis à percussão.

Os aluviões ocorrem em formato lenticular, localmente substituídos por aterros, com valores muito baixos de Nspt (geralmente inferior a 4) com espessura de até $6 \mathrm{~m}$ de argilas e lamas ricas em matéria orgânica (ALag) e com espessura de até $5 \mathrm{~m}$ de areias e cascalhos (Alar). Os aluviões ricos em cascalho podem apresentar valores elevados de Nspt, de até 55 .

As rochas sedimentares da Formação Resende estão representadas pelas subunidades de arenitos e conglomerados de canais de rios entrelaçados (RSel), lamitos argilosos a arenosos e argilitos de leques aluviais distais (RSId) e brechas e diamictitos de leques aluviais proximais (RSIp). 
A RSel apresenta-se associada a RSId, com maior ocorrência a partir da rua Barão do Triunfo (próxima a Av. Vereador José Diniz) até a região do Piscinão Água Espraiada. Há uma ocorrência restrita próxima a rua Niágara. Apresenta formato lenticular ou de canais com extensão variando entre 5 a $300 \mathrm{~m}$ e espessura de até $9 \mathrm{~m}$ Os valores de Nspt variam entre 5 a maior do que 50 , sendo menores mais próximos ao topo.

A RSId é a subunidade predominante na Formação Resende nesta seção. Sua distribuição é predominante entre Rua Princesa Isabel e o Piscinão Água Espraiada, mas também ocorre entre a rua Oscar Gomes Cardim e a Rua Pitu e na Estação Chucri Zaidan. Apresenta valores predominantemente altos de Nspt, em geral acima de 35, porém pode apresentar valores menores próximo ao topo e em porções localizadas.

A RSIp apresenta distribuição restrita, próxima as falhas normais localizadas nas ruas Princesa Isabel, Oscar Gomes Cardim e Pitu, É caracterizada pela presença de fragmentos de rocha, apresentando valores predominantemente altos de Nspt (impenetrável), com porções localizadas com valores baixos (até 4)

O embasamento ocorre entre a Av. das Nações Unidas até a Rua Pitu e entre a ruas Pitu e Oscar Gomes Cardim, interrompido pelas falhas normais. O solo eluvial (EMs1) ocorre de forma irregular, com espessura de até $6 \mathrm{~m}$. O solo de alteração (EMs2) ocorre na maioria das sondagens que interceptam o embasamento, com espessura de até $11 \mathrm{~m}$. A rocha alterada mole (EMr3) apresenta espessuras variáveis de até $28 \mathrm{~m}$.

A rocha sã ou alterada dura (EMr1/2) encontra-se em profundidades variáveis com mínimo de $13 \mathrm{~m}$ abaixo da superfície do terreno. Em geral, apresenta fraturamento elevado e baixo RQD. A resistência do maciço rochoso foi avaliada por meio da execução de ensaios de Resistência à Compressão Uniaxial (RCU). Os resultados destes ensaios indicaram significativa variabilidade na resistência da rocha, com valores distribuídos entre 2 a $105 \mathrm{MPa}$ e frequência predominante entre 8 e 25 MPa neste trecho. 


\subsubsection{Seção C}

Na seção C ocorrem aterros, aluviões e rochas sedimentares das formações São Paulo e Resende, conforme indicado na Figura 18.

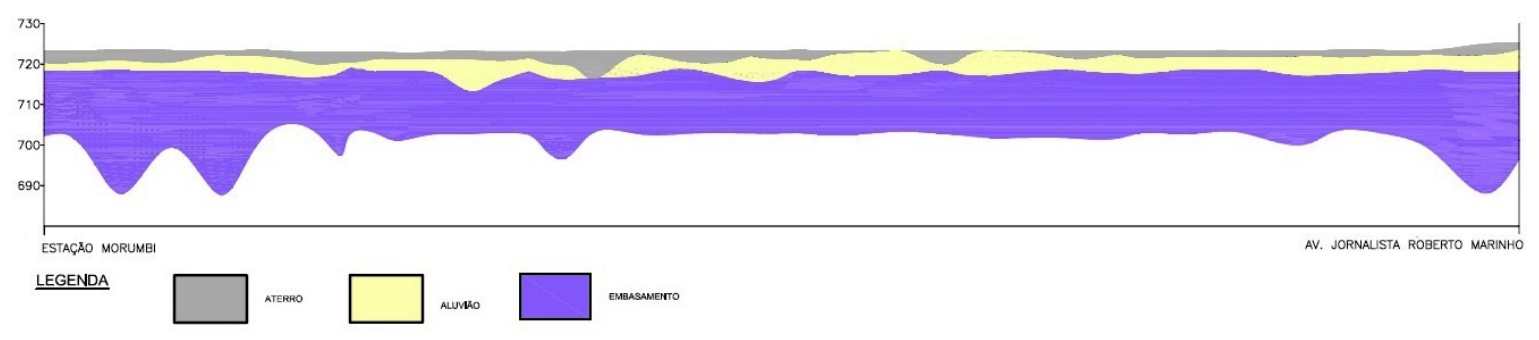

Figura 18 - Seção geológica esquemática C (para seção completa ver anexo).

Os aterros (AT) ou depósitos tecnogênicos recobrem superficialmente a maior parte do trecho com espessura variável de até $7 \mathrm{~m}$ e valores predominantemente baixos de Nspt.

Os aluviões foram identificados na maioria das sondagens, com exceção da sondagem SM-490, apresentando valores muito baixos de Nspt (geralmente inferior a 2) com espessura de até $3 \mathrm{~m}$ de argilas e lamas ricas em matéria orgânica (ALag) e de até $10 \mathrm{~m}$ de areias e cascalhos (Alar). Os aluviões ricos em cascalho podem apresentar valores elevados de Nspt, de até 55.

O embasamento ocorre em toda a extensão da seção. O solo eluvial (EMs1) ocorre localmente entre a Av. Roque Petroni e a Estação do Morumbi, com espessura de até $4 \mathrm{~m}$. O solo de alteração (EMs2) ocorre na maioria das sondagens, com espessura de até $8 \mathrm{~m}$. A rocha alterada mole (EMr3) apresenta espessuras variáveis de até $30 \mathrm{~m}$ próximo a Av. Jornalista Roberto Marinho e de até $13 \mathrm{~m}$ próximo a avenida Roque Petroni.

A rocha sã ou alterada dura (EMr1/2) encontra-se em profundidades variáveis entre $5 \mathrm{~m}$ até acima de $37 \mathrm{~m}$ abaixo da superfície do terreno. Em geral, apresenta fraturamento elevado e baixo RQD. Os resultados dos ensaios de Resistência à Compressão Uniaxial (RCU) indicaram significativa variabilidade na resistência da 
rocha, com valores distribuídos entre 2 a 197MPa e frequência predominante entre 10 e 30MPa.

\subsection{INTERPRETAÇÕES GEOLÓGICAS}

As coberturas quaternárias constituídas por depósitos aluviais associados a sistema fluvial meandrante tem ocorrência generalizada, pois a região corresponde às áreas de deposição do rio Pinheiros e córrego Água Espraiada. Estes depósitos são constituídos por argilas e lamas ricas em matéria orgânica, de coloração preta ou cinza escuro, moles a muito moles e areias e cascalhos podendo conter matéria orgânica, de coloração amarela a cinza escuro, fofas a compactas (com valores elevados de Nspt associados às camadas com cascalho).

As rochas sedimentares paleógenas da Bacia de São Paulo são representadas pelas formações São Paulo e Resende. A Formação São Paulo ocorre ao longo da Avenida Washington Luís. A Formação Resende ocorre ao longo da Av. Wahington Luís, sotoposta à Formação São Paulo, e ao longo da Avenida Jornalista Roberto Marinho, sendo predominante no trecho entre o Piscinão da Água Espraiada e o cruzamento com a Rua Princesa Isabel, além de ocorrências entre o cruzamento com as Rua Oscar Gomes Cardim até a Praça Ubirajara e próximo ao cruzamento com a Avenida Chucri Zaidan. Estas interrupções na continuidade dos depósitos da Formação Resende correspondem aos altos estruturais (horsts) e contatos com o embasamento. Estes contatos correspondem a ocorrência de falhas normais sin-sedimentares, com rejeitos podendo superar $20 \mathrm{~m}$, sendo que próximo a elas desenvolvem-se leques aluviais proximais constituídos por fragmentos e blocos do embasamento em meio a matriz lamítica a arenosa, predominantemente cinza e com valores altos de Nspt.

Com o afastamento da região do contato com o embasamento passam a predominar os depósitos relacionados a leques aluviais medianos a distais, constituídos por camadas lamíticas a argilosas de coloração predominantemente cinza esverdeado e marrom, podendo conter fragmentos esparsos de quartzo, com valores 
medianos a muito elevados de Nspt (com predomínio entre 10 a 30 golpes nos primeiros $10 \mathrm{~m}$ e entre 25 a 50 golpes abaixo desta profundidade). Estas camadas são predominantes no trecho estudado da Linha 17- Ouro do Metrô-SP, podendo apresentar espessura contínua superior a $30 \mathrm{~m}$.

As camadas relacionadas aos leques aluviais medianos a distais estão associadas a depósitos de rios entrelaçados, constituídos predominantemente por arenitos e conglomerados, de coloração cinza a amarelo, com espessura geralmente inferior a $5 \mathrm{~m}$ e valores medianos a elevados de Nspt (em geral, acima de 20 golpes).

O embasamento pré-cambriano predomina na região da Marginal Pinheiros, com ocorrências restritas na Avenida Jornalista Roberto Marinho, como no horst situado entre o cruzamento com as ruas Princesa Isabel e Oscar Gomes Cardim. O embasamento rochoso é constituído por gnaisses graníticos a biotíticos e migmatitos do Complexo Embu, localmente cortado por veios pegmatíticos correlacionados a intrusões graníticas.

O manto de intemperismo nestas rochas foi interpretado de acordo com o perfil de intemperismo proposto por Vaz (1996), com base na identificação de uma camada superficial correspondente ao solo eluvial (silte argiloso a pouco arenoso) com valores de Nspt inferiores a 10, seguido de solo de alteração (silte arenoso, micáceo), com valores de Nspt entre 10 e 50e uma camada de rocha alterada mole (biotita gnaisse alterado com porções ricas em silte arenoso, micáceo) com valores de Nspt geralmente acima de 50 até impenetrável. A espessura do manto de intemperismo pode variar entre $2 \mathrm{~m}$ (na Marginal Pinheiros) a 30m no alinhamento do Córrego Água Espraiada.

A resistência do maciço rochoso foi avaliada mediante ensaios de Resistência à Compressão Uniaxial (RCU), sendo sempre 3 amostras por sondagem, a primeira próxima ao topo rochoso, a segunda no meio e a terceira ao final da sondagem, com profundidade máxima de $35 \mathrm{~m}$ em relação ao nível do terreno. Estas sondagens estão situadas ao longo das avenidas Jornalista Roberto Marinho e das Nações Unidas, 
incluindo sondagens situadas além da Estação Morumbi, que não fazem parte da Seção C.

Os resultados destes ensaios indicaram significativa variabilidade na resistência da rocha (Figura 19), com valores distribuídos entre 2 a 197MPa, com frequência predominante entre 10 e $30 \mathrm{MPa}$.

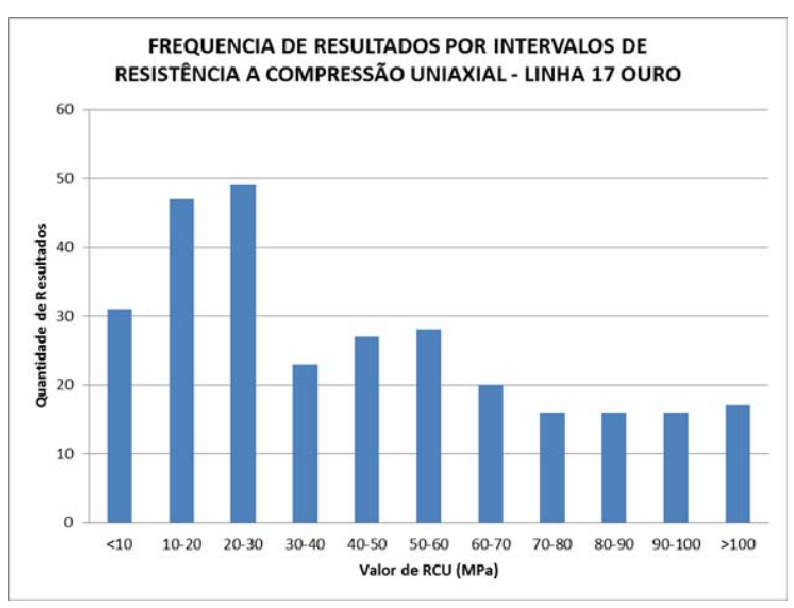

Figura 19 - Resultados de RCU por intervalos de valores.

Se os resultados forem analisados em relação a distância do topo rochoso, há uma predominância de resultados entre 10 e 30MPa para a primeira e segunda amostras e entre 40 e 60MPa para a terceira amostra (Figura 20). No entanto somente $37 \%$ das 92 sondagens analisadas apresentaram resistência crescente com a profundidade (RCU Amostra $1<$ RCU Amostra $2<$ RCU Amostra 3).

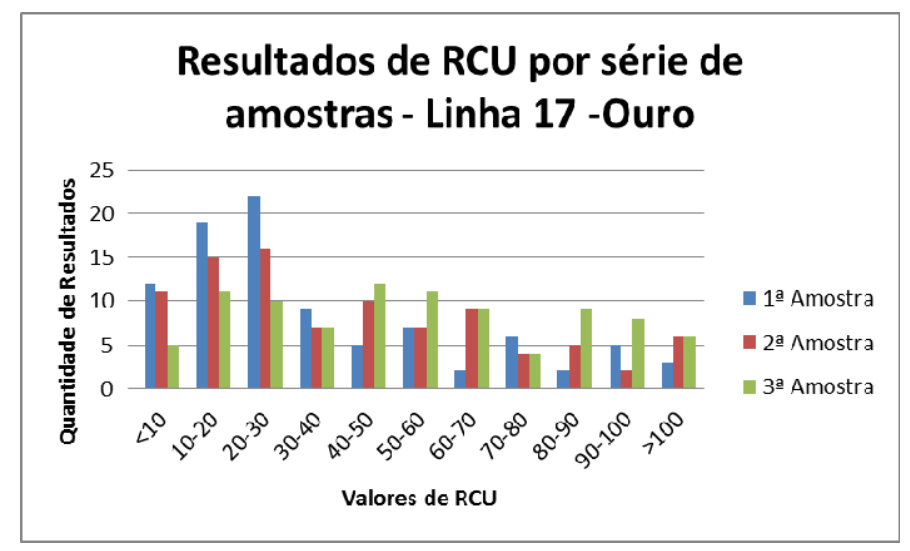

Figura 20 - Resultados de RCU por séries de amostra. 
Este comportamento indica que outros fatores, além da profundidade em relação ao topo rochoso / proximidade do manto de intemperismo, controlam a resistência da rocha neste trecho do Complexo Embu. Estes fatores poderia ser o controle litológico e a presença de deformações. As camadas constituídas predominantemente por biotita tendem a apresentar resistência menor que as camadas ricas em quartzo e feldpato. A presença de dobras e foliação orientadas em planos desfavoráveis em relação ao esforço induzido no ensaio também reduzem a resistência independente da profundidade (Figura 21).

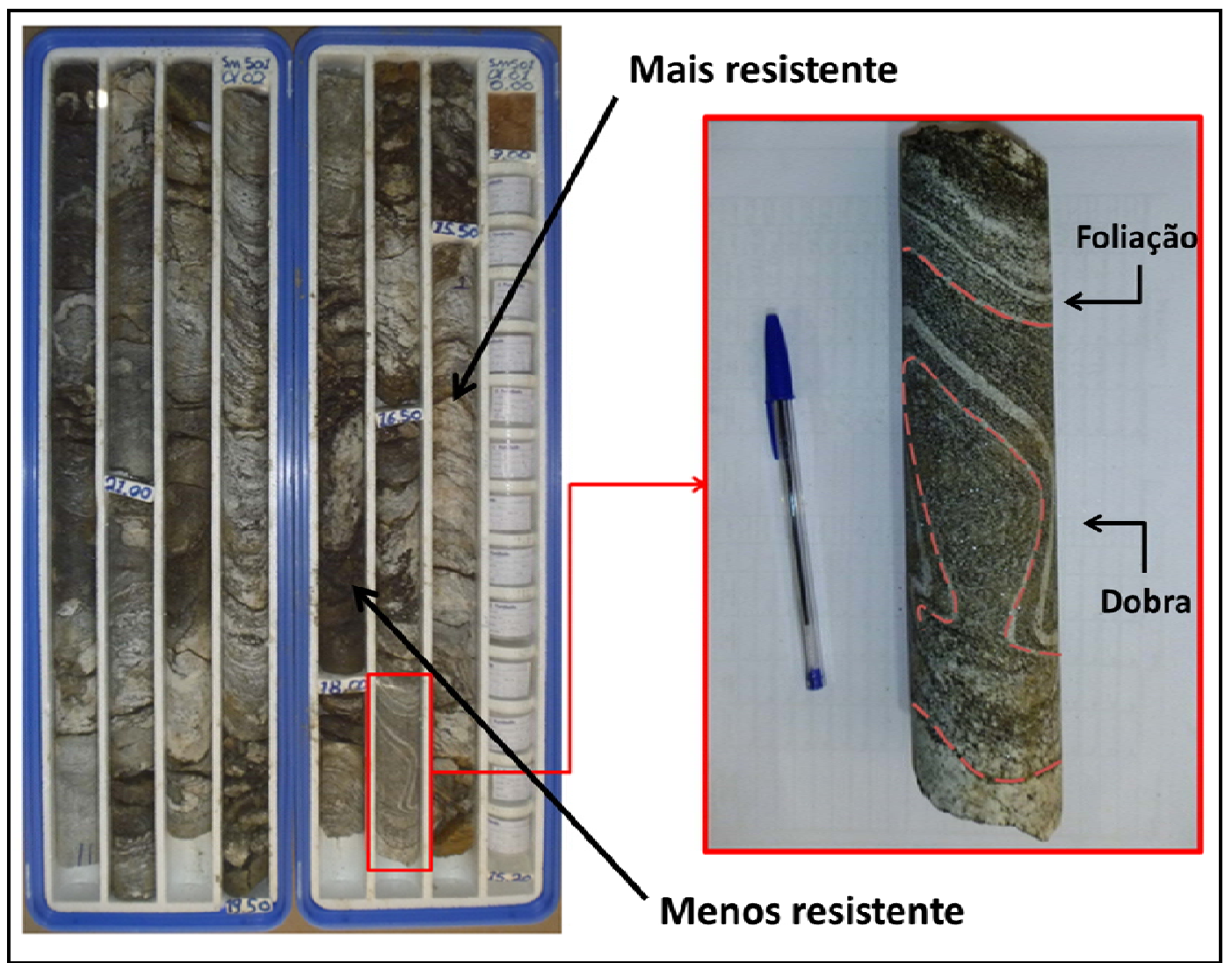

Figura 21 - Sondagem mista (SM-501) indicando controle litológico e presença de deformação dúctil. 


\section{DISCUSSÃO DOS RESULTADOS}

Este estudo baseou-se na análise e interpretação de sondagens executadas com o objetivo de investigar e projetar as fundações da Linha 17 - Ouro do Metrô-SP. Estas sondagens apresentaram espaçamento médio de $30 \mathrm{~m}$ e profundidade média de 30m, o que resultou em uma razoável densidade de informações, porém a uma profundidade relativamente rasa.

Como as sondagens foram executadas ao longo de três avenidas, somando cerca de $6 \mathrm{~km}$ de extensão, em diferentes cotas de superfície (entre as cotas 788 e $722 \mathrm{~m}$ ), foi possível interceptar os três principais compartimentos geológicos de São Paulo: o embasamento pré-cambriano, as rochas sedimentares paleógenas da Bacia de São Paulo e os depósitos aluviais do Quaternário, além dos depósitos tecnogênicos ou aterros. A Tabela 4 apresenta da sistematização das unidades geológico-geotécnicas da Bacia de São Paulo utilizadas neste trabalho.

Os aterros apresentam composição variada, podendo conter desde camadas de argilas ricas em matéria orgânica, até camadas de areias ou fragmentos de rocha. Há porém um predomínio de argila siltosa a arenosa, com valores baixos de Nspt.

Os aluviões em geral são pouco espessos quando comparado com os depósitos paleógenos, com menos de uma dezena de metros de espessura máxima, apresentando baixa resistência, com valores reduzidos de Nspt (com predomínio entre 0 e 5$)$.

As rochas sedimentares da Formação São Paulo ocorrem ao longo da Av. Washington Luís, apresentando maior variabilidade nas camadas, com intercalações entre os argilitos e lamitos argilosos provenientes de meandros abandonados e os arenitos e conglomerados provenientes de canais de rios meandrantes ou arenitos de rompimento de diques marginais. A porção de lamitos argilosos alterados, gerada por intemperismo, apresenta distribuição homogênea próxima à superfície, predominantemente a partir da cota $770 \mathrm{~m}$. Os valores de Nspt tendem a ser menores próximos ao topo, porém podem apresentar valores baixos em porções mais 
profundas. Localmente, camadas ricas em seixos e cascalhos ou que apresentam concreções limoníticas podem elevar o valor de Nspt.

Tabela 4 - Síntese da sistematização das unidades geológico-geotécnicas da Bacia de São Paulo

\begin{tabular}{|c|c|c|}
\hline Estratigrafia & $\begin{array}{l}\text { Unidade } \\
\text { geológico- } \\
\text { geotécnica }\end{array}$ & Descrição \\
\hline Aterro & AT & Depósitos tecnogênicos de composição variada \\
\hline \multirow[t]{2}{*}{ Aluvião } & ALag & $\begin{array}{l}\text { Depósitos fluviais meandrantes de planície de inundação ou } \\
\text { meandros abandonados, compostos por argilas e lamas ricas } \\
\text { em matéria orgânica }\end{array}$ \\
\hline & ALar & $\begin{array}{l}\text { Depósitos fluviais de canais meandrantes, compostos por } \\
\text { areias e cascalhos }\end{array}$ \\
\hline \multirow{3}{*}{$\begin{array}{l}\text { Formação } \\
\text { São Paulo }\end{array}$} & SPal & Camada superficial alterada, composta por lamitos argilosos \\
\hline & SPag & $\begin{array}{l}\text { Depósitos fluviais meandrantes de planície de inundação ou } \\
\text { meandros abandonados, compostos por argilitos e lamitos } \\
\text { argilosos }\end{array}$ \\
\hline & SPar & $\begin{array}{l}\text { Depósitos fluviais de canais meandrantes ou de rompimento } \\
\text { de diques marginais, compostos por arenitos e conglomerados }\end{array}$ \\
\hline \multirow{3}{*}{$\begin{array}{l}\text { Formação } \\
\text { Resende }\end{array}$} & RSel & $\begin{array}{l}\text { Depósitos fluviais provenientes de canais de rios entrelaçados, } \\
\text { compostos por arenitos e conglomerados }\end{array}$ \\
\hline & RSId & $\begin{array}{l}\text { Depósitos de leques aluviais medianos a distais, compostos } \\
\text { por lamitos argilosos a arenosos e argilitos }\end{array}$ \\
\hline & RSIp & $\begin{array}{l}\text { Depósitos de leques aluviais proximais, compostos por } \\
\text { brechas e diamictitos }\end{array}$ \\
\hline \multirow{4}{*}{ Embasamento } & EMs1 & Solo eluvial constituído por siltes argilosos a arenosos \\
\hline & EMs2 & $\begin{array}{l}\text { Solo de alteração de rocha constituído predominantemente por } \\
\text { siltes arenosos micáceos }\end{array}$ \\
\hline & EMr3 & $\begin{array}{l}\text { Rocha alterada mole constituída predominantemente por } \\
\text { biotita gnaisse muito alterado }\end{array}$ \\
\hline & $\mathrm{EMr} 1 / 2$ & $\begin{array}{l}\text { Rocha sã ou rocha alterada dura constituída } \\
\text { predominantemente por biotita gnaisse }\end{array}$ \\
\hline
\end{tabular}

\section{O contato entre a Formação São Paulo e Formação Resende ocorre próximo à} cota $740 \mathrm{~m}$, porém podem haver escavações locais da Formação São Paulo, como 
observado nas sondagens SP-516, SP-522 e SP-531. Este contato do tipo erosivo é comum próximo a região central da Bacia de São Paulo, mas próximo a borda podem haver interdigitações entre os leques aluviais da Formação Resende e os depósitos fluviais meandrantes da Formação São Paulo.

A Formação Resende representa a maior parte do preenchimento sedimentar da Bacia de São Paulo, sendo predominante também na área estudada neste trabalho. Há um predomínio dos lamitos e argilitos provenientes dos leques aluviais distais, que apresentam valores em geral elevados de Nspt, podendo chegar até mesmo superar o valor de 50 .

Os arenitos e conglomerados de canais de rios entrelaçados são mais comuns nas regiões mais distantes do contato com o embasamento, como entre a Av. Vereador José Diniz e o Piscinão Água Espraiada e na Av. Washington Luís. Apresentam espessura e distribuição relativamente menor quando comparados aos depósitos de leques aluviais. Porém é fundamental identificar a presença desta unidade para a elaboração de projetos de engenharia, pois apresentam a maior permeabilidade e menor coesão da Formação Resende.

Em amostras de sondagem não é possível visualizar a geometria nem separar os diferentes canais, sendo que nas seções geológicas podem ser interpretados como uma única camada os depósitos de diferentes canais, conforme indicado na Figura 22. 


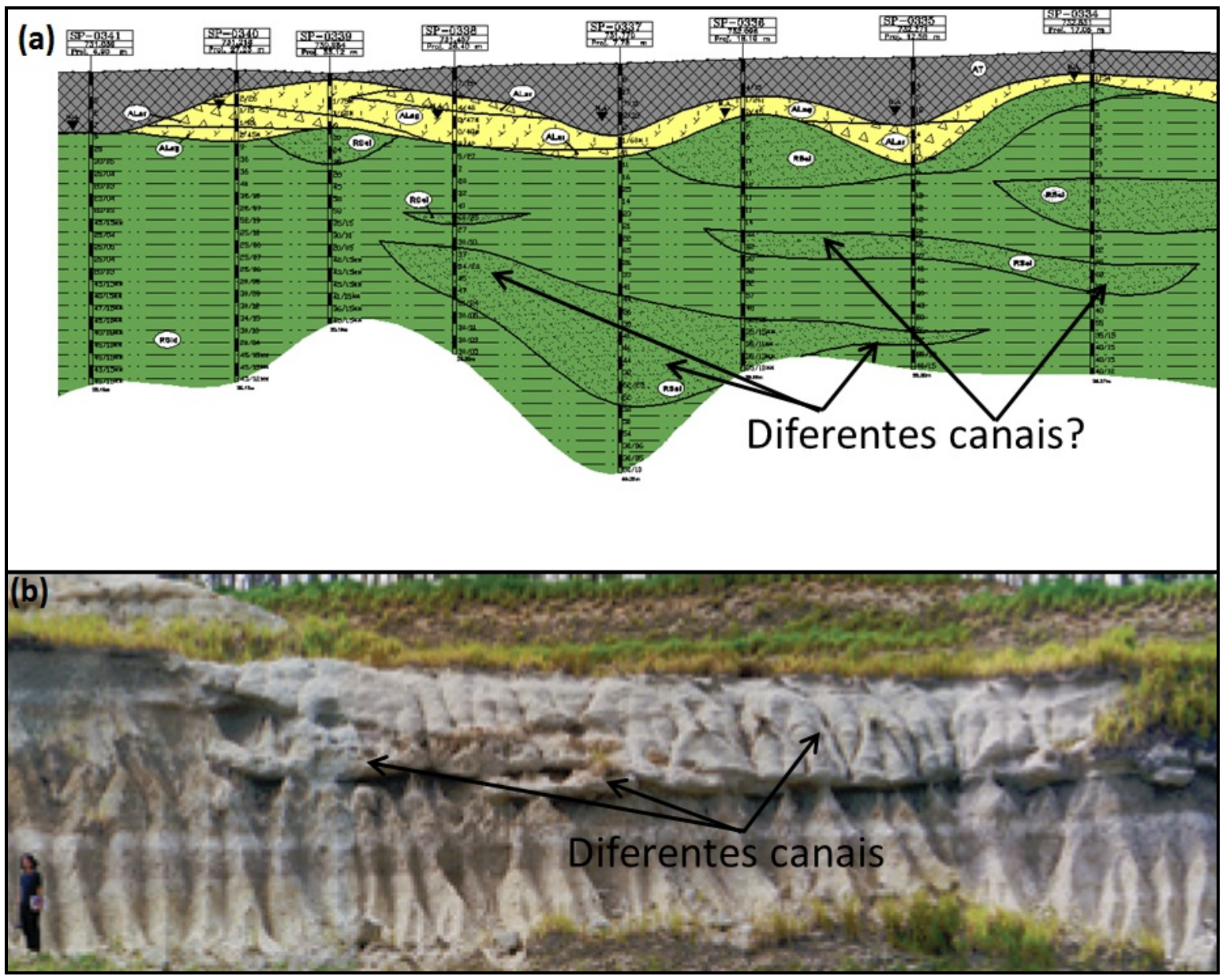

Figura 22 - Possibilidade de interpretação de um ou mais canais em parte da Seção B (a) em comparação com a fotografia de um afloramento da Formação Resende tirada na Rodovia Presidente Dom Pedro I próximo ao cruzamento com a Rodovia Presidente Dutra (b). Fonte: Modificado de Riccomini et al. (2004).

Os leques aluviais proximais ocorrem próximos às falhas normais marcando o contato entre a Formação Resende e o embasamento. Estas falhas normais foram interpretadas como sin-sedimentares com rejeito de $19 \mathrm{~m}$, conforme observado entre as sondagens SM-365 e SM-362. Os depósitos de leques aluviais proximais podem apresentar valores elevados de Nspt, chegando até o impenetrável. A Figura 23 apresenta a comparação entre o contato por falha normal observada próxima a rua Pitu e o contato por falha normal observado nas escavações da Linha 5 - Lilás do Metrô de São Paulo, próximo ao Largo 13. 


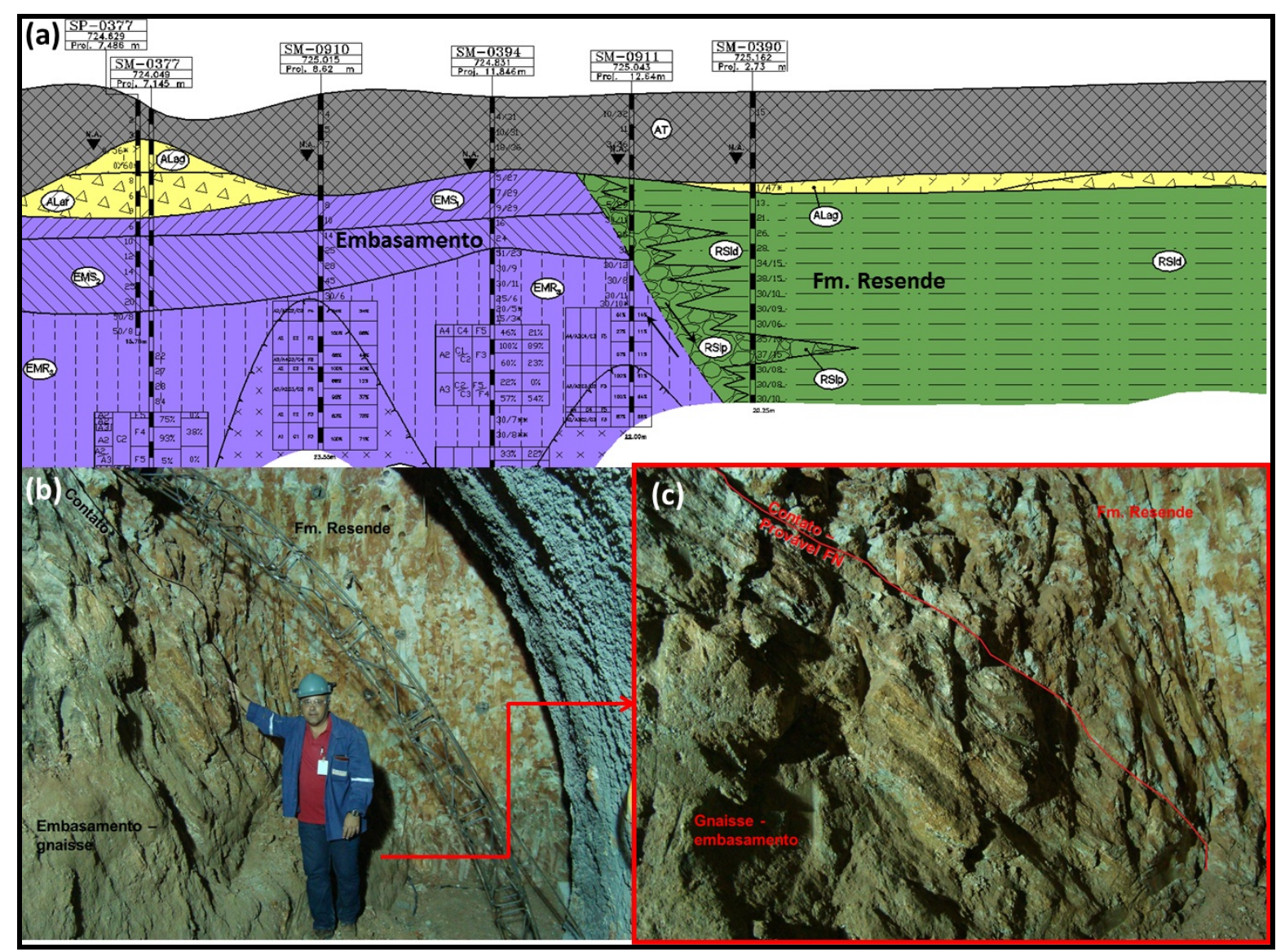

Figura 22 - Comparação entre o contato entre a Formação Resende observado na Seção B (a) com as fotografias tiradas na escavação da Linha 5 - Lilás do Metrô-SP (b) e detalhe (c).

Como estes depósitos apresentam distribuição restrita, o espaçamento de 30m entre as sondagens muitas vezes não é suficiente para interceptá-los. O plano das falhas que marcam o contato dificilmente podem ser analisados a partir de sondagens rotativas, pois há perda de material nesta manobra e o material próximo à falha tende a fragmentar-se. O televisionamento de furos de sondagem mostra-se como uma boa técnica para medição e análise das falhas e contatos, porém não foi realizado para este estudo.

Para as unidades sedimentares identificadas neste estudo (aluviões, Formação São Paulo e Formação Resende) foi feita uma correlação com os parâmetros geotécnicos apresentados no item 5, como peso específico $(\gamma)$, coesão efetiva $\left(c^{\prime}\right)$, ângulo de atrito interno $\left(\phi^{\prime}\right)$, coeficiente de empuxo em repouso $\left(K_{0}\right)$, coeficiente de apoio elástico horizontal (Kh), módulo de elasticidade (E) e coeficiente de 
permeabilidade (K). A Tabela 5 a seguir apresenta estes resultados em função dos valores de Nspt, indicando as variações que pode haver dentro de cada unidade.

Tabela 5 - Parâmetros geotécnicos das unidades geológico-geotécnicas obtidos a partir da correlação com os dados do item 5.2 e literatura.

\begin{tabular}{|c|c|c|c|c|c|c|c|c|}
\hline Unidade & Nspt & $\boldsymbol{V}\left(\mathrm{kN} / \mathrm{m}^{3}\right)$ & $C^{\prime}\left(k N / m^{2}\right)$ & $\phi^{\prime}\left(^{\circ}\right)$ & $\mathrm{K}_{0}$ & Kh & $E$ & $\mathrm{k}(\mathrm{cm} / \mathrm{s})$ \\
\hline ALag & 0 a 4 & 16,0 & 8 & 20 & 0,83 & 2,08 & 3,2 & $10^{-5}$ a $10^{-4}$ \\
\hline ALar & 1 a 9 & 17,0 & 5 & 28 & 0,73 & 5,20 & 8,0 & $10^{-3}$ a $5.10^{-3}$ \\
\hline \multirow{3}{*}{ SPal } & 2 a 4 & 15,0 & 20 & 27 & 0,60 & 3,90 & 6,0 & $5.10^{-4}$ \\
\hline & 5 a 10 & 16,0 & 20 & 27 & 0,60 & 9,75 & 15,0 & $5.10^{-4}$ \\
\hline & $>10$ & 18,0 & 40 & 25 & 0,60 & 19,50 & 30,0 & $5.10^{-4}$ \\
\hline \multirow{7}{*}{ SPag } & 3 a 5 & 17,0 & 25 & 27 & 0,90 & 5,20 & 8,0 & $5.10^{-4}$ \\
\hline & 5 a 8 & 18,0 & 30 & 25 & 0,90 & 9,75 & 15,0 & $5.10^{-4}$ \\
\hline & 8 a 12 & 19,0 & 40 & 24 & 0,90 & 13,00 & 20,0 & $5.10^{-4}$ \\
\hline & 12 a 18 & 20,0 & 50 & 23 & 0,90 & 19,50 & 30,0 & $5.10^{-4}$ \\
\hline & 18 a 25 & 20,0 & 75 & 22 & 0,80 & 29,25 & 45,0 & $5.10^{-4}$ \\
\hline & 25 a 40 & 20,0 & 100 & 21 & 0,80 & 42,25 & 65,0 & $5.10^{-4}$ \\
\hline & $>40$ & 20,0 & 150 & 20 & 0,80 & 65,00 & 100,0 & $5.10^{-4}$ \\
\hline \multirow{3}{*}{ SPar } & 5 a 10 & 19,0 & 3 & 30 & 0,80 & 6,50 & 10,0 & $10^{-4}$ a $10^{-3}$ \\
\hline & 10 a 20 & 19,0 & 3 & 32 & 0,80 & 19,50 & 30,0 & $10^{-4}$ a $10^{-3}$ \\
\hline & $>20$ & 19,0 & 3 & 35 & 0,80 & 32,50 & 50,0 & $10^{-4}$ a $10^{-3}$ \\
\hline \multirow{3}{*}{ RSel } & 5 a 10 & 19,0 & 5 & 30 & 0,80 & 9,75 & 15,0 & $10^{-4}$ a $10^{-2}$ \\
\hline & 10 a 20 & 20,0 & 5 & 32 & 0,80 & 19,50 & 30,0 & $10^{-4}$ a $10^{-2}$ \\
\hline & $>20$ & 20,6 & 5 & 35 & 0,80 & 32,50 & 50,0 & $10^{-4}$ a $10^{-2}$ \\
\hline \multirow{7}{*}{ RSId e Ip } & 3 a 5 & 19,0 & 25 & 27 & 0,80 & 5,20 & 8,0 & $10^{-7}$ a $10^{-6}$ \\
\hline & 5 a 8 & 19,5 & 30 & 25 & 0,80 & 9,75 & 15,0 & $10^{-7}$ a $10^{-6}$ \\
\hline & 8 a 12 & 20,0 & 40 & 24 & 0,80 & 13,00 & 20,0 & $10^{-7}$ a $10^{-6}$ \\
\hline & 12 a 18 & 20,5 & 50 & 23 & 0,80 & 19,50 & 30,0 & $10^{-7}$ a $10^{-6}$ \\
\hline & 18 a 25 & 21,0 & 75 & 22 & 0,80 & 29,25 & 45,0 & $10^{-7}$ a $10^{-6}$ \\
\hline & 25 a 40 & 21,5 & 100 & 21 & 0,80 & 42,25 & 65,0 & $10^{-7}$ a $10^{-6}$ \\
\hline & $>40$ & 21,5 & 150 & 20 & 0,80 & 65,00 & 100,0 & $10^{-7}$ \\
\hline
\end{tabular}

O embasamento identificado corresponde ao Biotita Gnaisse do Complexo Embu, localmente cortado por veios pegmatíticos relacionados às intrusões graníticas. Sua distribuição é predominante na região da Marginal Pinheiros, sendo que um alto 
estrutural ou horst foi identificado na Av. Jornalista Roberto Marinho, entre o cruzamento com as ruas Oscar Gomes Cardim e Pitu.

O manto de intemperismo do embasamento pode superar $35 \mathrm{~m}$ de profundidade e a rocha apresenta-se em geral muito fraturada e com valores variáveis de resistência a compressão uniaxial, com predomínio entre 10 e $30 \mathrm{MPa}$.

\section{CONCLUSÕES}

Este estudo apresentou uma proposta de sistematização das unidades geológico-geotécnicas presentes na Bacia de São Paulo. Para tal foram analisadas sondagens mistas e a percussão executadas ao longo das Avenidas Washington Luís, Jornalista Roberto Marinho e das Nações Unidas (Marginal Pinheiros), correspondente ao primeiro trecho da Linha 17 - Ouro do Metrô-SP.

Através da realização de classificação tátil-visual das amostras de sondagem, análise dos ensaios geotécnicos (SPT- Standard Penetration Test e RCU - Resistência a Compressão Uniaxial) em comparação com os dados disponíveis na literatura foram definidas as unidades geológico-geotécnicas presentes na área, contemplando os principais compartimentos presentes na Região Metropolitana de São Paulo: embasamento pré-cambriano (representado pelo Complexo Embu), rochas sedimentares da Bacia de São Paulo (representada pelas formações Resende e São Paulo), depósitos aluviais e depósitos tecnogênicos.

As sondagens utilizadas apresentam espaçamento médio de $30 \mathrm{~m}$ e profundidade média da mesma ordem, permitindo a elaboração de seções geológicogeotécnicas de detalhe. A Seção A foi elaborada na Av. Washington Luís e apresenta uma camada superficial de aterro (depósitos tecnogênicos), seguido de porções localizadas pouco espessas de depósitos aluviais, sobre as formações São Paulo e Resende. O contato entre as formações paleógenas ocorre em torno da cota 740m, 
porém foram identificadas escavações de canais meandrantes da Fm. São Paulo nos depósitos relacionados a leques aluviais medianos a distais da Fm. Resende indicando contato erosivo.

Os depósitos tecnogênicos e aluviais apresentam valores baixos de Nspt indicando baixa capacidade de carga como fundações. Em relação a Bacia Sedimentar de São Paulo, pode-se observar ao longo da seção que os valores de Nspt na Formação São Paulo são relativamente menores quando comparados a Formação Resende.

A seção B foi realizada na Av. Jornalista Roberto Marinho, apresentando uma camada superficial de aterro (depósitos tecnogênicos), seguido de depósitos aluviais com distribuição e espessura relativamente maiores que na seção $A$, sobre a Formação Resende e embasamento.

Nesta seção há predomínio da Formação Resende, sendo que os valores de Nspt são frequentemente elevados atingindo até mesmo o impenetrável. Entre o cruzamento com a Av. Vereador José Diniz até o Piscinão da Água Espraiada ocorrem os depósitos relacionados aos leques aluviais medianos a distais associados a canais de rios entrelaçados. Foi possível identificar três falhas normais sin-sedimentares próxima ao cruzamento com as ruas Princesa Isabel, Oscar Gomes Cardim e Pitu, próximas das quais ocorrem os depósitos de leques aluviais proximais.

O embasamento ocorre entre a Rua Pitu e o cruzamento com a Av. das Nações Unidas, sendo que foi identificado um horst entre as ruas Oscar Gomes Cardim e Princesa Isabel. Próximo ao topo, as rochas do embasamento são alteradas devido a ação de intemperismo, resultando em um manto de alteração que pode superar $35 \mathrm{~m}$. Os valores de Nspt tendem a ser menores próximos ao topo e aumentar com a profundidade.

A seção C foi realizada na Avenida das Nações Unidas (Marginal Pinheiros) apresentando uma camada superficial de aterro, seguido de depósitos aluviais com distribuição e espessura semelhante a seção B, sobre o embasamento. Assim como na Seção B, o embasamento encontra-se alterado devido ao intemperismo próximo ao 
topo e pode apresentar elevado grau de fraturamento, com baixo valor de RQD e resistência a compressão uniaxial predominantemente entre 10 a $30 \mathrm{MPa}$, podendo atingir até $197 \mathrm{MPa}$.

A proposta de sistematização das unidades geológico-geotécnicas utilizada neste trabalho mostrou-se adequada para a interpretação de seções indicando a posição espacial dos materiais com características geológicas e geotécnicas similares. Os dados dos ensaios SPT e RCU foram analisados de acordo com esta sistematização, permitindo a identificação das camadas mais e menos resistentes e variações dentro de uma mesma camada.

A correlação entre os dados geológicos e geotécnicos a partir de dados de sondagens e da literatura na Bacia de São Paulo foi realizada aliando-se os conhecimentos dos processos geológicos envolvidos na formação de cada unidade geológica, com as análises das amostras de sondagens e ensaios geotécnicos. Esta correlação parte da estratigrafia definida para a Bacia de São Paulo, combinando-se com os estudos geotécnicos das áreas de mecânica dos solos (que inclui sedimentos e rochas sedimentares) e mecânica das rochas.

Este estudo pode ainda ser complementado, a partir da identificação e caracterização de novas unidades geológico-geotécnicas presentes na Bacia de São Paulo, como definidas a partir das rochas sedimentares das formações Tremembé e Itaquaquecetuba, dos depósitos coluviais ou mesmo dos diferentes litotipos que compõem o embasamento da bacia.

A caracterização das unidades já identificadas pode ser detalhada a partir da incorporação de dados provenientes da realização de novos ensaios como de petrografia, microscopia eletrônica de varredura, difração de raios X, granulometria, ensaios triaxiais, abrasão cerchar, determinação de parâmetros geotécnicos a partir de amostras indeformadas, ensaios de campo, ou mesmo a classificação geomecânica do trecho correspondente ao embasamento. 


\section{REFERÊNCIAS BIBLIOGRÁFICAS}

ABGE (ASSOCIAÇÃO BRASILEIRA DE GEOLOGIA DE ENGENHARIA) / SBG (SOCIEDADE BRASILEIRA DE GEOLOGIA). 1980. Aspectos geológicos e geotécnicos da Bacia Sedimentar de São Paulo. Publicação especial, Mesa Redonda, São Paulo.

ABGE (ASSOCIAÇÃO BRASILEIRA DE GEOLOGIA DE ENGENHARIA). 1999. Manual de Sondagens, Boletim n. $\quad 3$, 4a edição. São Paulo, $75 p$.

ABNT (ASSOCIAÇÃO BRASILEIRA DE NORMAS TÉCNICAS). NBR-6484/2010 - Execução de Sondagem de Simples Reconhecimento dos Solos.

ABMS (ASSOCIAÇÃO BRASILEIRA DE MECÂNICA DOS SOLOS) / ABEF (ASSOCIAÇÃO BRASILEIRA DE ENGENHARIA DE FUNDAÇÕES). 1992. Solos da Cidade de São Paulo. Publicação especial, Mesa Redonda, São Paulo, 362p.

ABMS (ASSOCIAÇÃO BRASILEIRA DE MECÂNICA DOS SOLOS). 2012. Twin Cities: Solos da Cidade de São Paulo e Curitiba. Publicação especial, Mesa Redonda, São Paulo, 506p.

ALMEIDA, F.F.M. 1967. Origem e evolução da Plataforma Brasileira. Boletim do Departamento Nacional de Produção Mineral, Divisão de Geologia e Mineralogia. Rio de Janeiro, n. 241, 36p.

ALMEIDA, F.F.M. 1983. Relações tectônicas das rochas alcalinas mesozóicas da região meridional da plataforma sul-americana. Revista Brasileira de Geociências, 13:139-158.

ALMEIDA, F.F.M.; AMARAL, G.; CORDANI, U.G.; KAWASHITA, K. 1973. The Pre Cambrian evolution of the south american cratonic margin south of amazon river. In: NAIRN, A.E.; STEHLI, F.G. (Eds). The ocean basins and margins. Plenum publ., New York, 1:411-446.

ALMEIDA, F.F.M. \& HASUI, Y. 1984. O embasamento da plataforma Sul Americana. In: O Pré-Cambriano do Brasil. Edgard Blucher, São Paulo, p.1-5.

ALMEIDA, F.F.M.; HASUI, Y. \& BRITO NEVES, B.B. 1976. The Upper Precambrian of South America. Bol. IG-USP, São Paulo 7:45-80.

ALMEIDA, F.F.M.; HASUI, Y.; BRITO NEVES, B.B.; FUCK, R.A. 1977. Províncias estruturais brasileiras. In: Simpósio de Geologia do Nordeste, 8, Campina Grande, Atas, p.363-391.

AMADOR, E.S. 1975. Estratigrafia e sedimentação da Bacia de Resende, RJ. Anais da Academia Brasileira de Ciências, 47:181-225.

AOKI, N. \& CINTRA, J.C.A. 2000. The application of energy conservation Hamilton's principle to the determination of energy efficiency in SPT tests. In: International Conference on the application of stress-wave theory to piles. Proceedings, Roterdam, Balkema, p.457-460.

BELICANTA, A. \& CINTRA, J.C.A. 1998. Fatores intervenientes em variantes do método ABNT para execução de SPT. In: Solos e Rochas, 21:119-133. 
BERGMANN, M. 1988. Caracterização Estratigráfica e Estrutural da Sequência Vulcano-Sedimentar do Grupo São Roque, na região de Pirapora do Bom Jesus - SP. Dissertação de Mestrado, Instituto de Geociências, Universidade de São Paulo, São Paulo, 167p.

CAMPOS NETO, M.C. 2000. Orogenic systems from southwestern Gondwana: an approach to Brasiliano - Pan African cycle and orogenic collage in southeastern Brazil. In: Tectonic Evolution of South America. Cordani, U.G.; Milani, E.J.; Thomas Filho, A.; Campos, D.A. (Eds.) Rio de Janeiro, s.n, p.335-365.

CARNEIRO, C.D.R.; HASUI, Y.; DANTAS, A.S.L. 1984. Contribuição ao Estudo da Litoestratigrafia do Grupo São Roque na Faixa Jaraguá-Cristais-SP. In: Congresso Brasileiro de Geologia, 33, Rio de Janeiro, Anais, p.3212-3226.

CARVALHO, N. 2006. Túneis rodoviários. In: CELESTINO, T.B.; KOSHIMA, A.; TELLES, R.C.A.; ASSIS, A. (Eds.)Túneis do Brasil. CBT, DBA, p.26-107.

COIMBRA, A.M.; RICCOMINI, C.; MELO, M.S. 1983. A Formação Itaquaquecetuba: Evidências de tectonismo no quaternário paulista. In: Simpósio Regional de Geologia, 4, São Paulo, Anais, p. 253- 266.

COMPANHIA DE PESQUISA DE RECURSOS MINERAIS - SERVIÇO GEOLÓGICO DO BRASIL - CPRM. 2006. Mapa Geológico do Estado de São Paulo: Breve descrição das unidades litoestratigráficas aflorantes no Estado de São Paulo. Escala 1:750000. 173p.

COMPANHIA DO METROPOLITANO DE SÃO PAULO - CMSP. 2011. Relatórios Geológico-Geotécnicos do Projeto Básico da Linha 6 - Laranja. RT-6.24.00.00/4C3-001, RT-6.16.00.00/4C3-001, RT6.08.00.00/4C3-001 e RT-6.04.00.00/4C3-001, elaborados por Sistran Engenharia, Intertechne Consultores S.A., Consórcio Opus-Vetec e EBEI - Empresa Brasileira de Engenharia de Infraestrutura. São Paulo.

COMPANHIA DO METROPOLITANO DE SÃO PAULO - CMSP. 1994. Memorial justificativo dos parâmetros geotécnicos do Projeto Básico da Linha 4 - Amarela. RT-4.10.00.00/4C3-002, elaborado por Promon Engenharia. São Paulo.

CORDANI, U.G.; COUTINHO, J.M.V.; NUTMAN, A. 2002. Geochronological constraints on the evolution of the Embu Complex. São Paulo. Journal of South American Earth Sciences, 14:903-910.

COUTINHO, J.M.V. 1980a. Carta geológica da região metropolitana de São Paulo. Escala 1:100.000. São Paulo, EMPLASA, 2 folhas.

COUTINHO, J.M.V. 1980b. Relações litológicas e estruturais da Bacia de São Paulo com o Pré-Cambriano circunvizinho. In: Aspectos geológicos e geotécnicos da Bacia Sedimentar de São Paulo. ABGE/SBG-SP. São Paulo, p.15-23.

COZZOLINO, V.M.N. 1972. Tipos de sedimentos que constituem a Bacia de São Paulo. Tese de Doutoramento, Escola Politécnica da Universidade de São Paulo, São Paulo, 116p. 
COZZOLINO, V.M. 1980. Considerações sobre o conceito de camadas do ponto de vista geotécnico na Bacia de São Paulo. In: Mesa Redonda sobre Aspectos Geológicos e Geotécnicos na Bacia Sedimentar de São Paulo. ABGE/SBG, São Paulo, p.47-52

COZZOLINO, V.M. 1996. Areias basais fofas na área central da cidade de São Paulo. In: Revista Solos $e$ Rochas. São Paulo, 19:163-174.

COZZOLINO, V.M. \& CHIOSSI, N.J. 1969. A Bacia Sedimentar de São Paulo. In: Semana Paulista de Geologia Aplicada, 1, São Paulo, Anais.

COZZOLINO, V.M.; MARTINATI, L.R.; BUONO, A.V.D. 1994. Contribuição ao estudo dos movimentos tectônicos sin e pós-sedimentares da Bacia de São Paulo a partir de evidências observadas nas escavações do Túnel da Eletropaulo. In: Solos e Rochas, São Paulo, 17:13-29.

DEERE, D.U.; HENDRON, A.J.; PATTON, F.D.; CORDING, E.J. 1967. Design of surface and near surface construction in rock. In: U.S. Symp. Rock. Mech., AIME, New York, p.237-302.

GALVES, M.L. \& MASSAD, F. 1982. Características geotécnicas de argilas duras cinza-esverdeadas da Bacia Sedimentar de São Paulo. In: Congresso Brasileiro de Mecânica dos Solos e Engenharia de Fundações, 7, Olinda, Anais.

GOOGLEMAPS. 2013. Disponível no endereço: https://maps.google.com.br/

FERNANDES, A.J. 1991. O Complexo Embu no leste do Estado de São Paulo: contribuição ao conhecimento da litoestratigrafia e da evolução estrutural e metamórfica. Dissertação de Mestrado. Instituto de Geociências, Universidade de São Paulo. São Paulo, 120p.

FERRARI, A.L. 2001. Evolução tectônica do Gráben da Guanabara. Tese de Doutoramento. Instituto de Geociências, Universidade de São Paulo. São Paulo, 412p.

GAWTHORPE, R. L. \& COLLELA, A. 1990. Tectonic controls on coarse-grained delta depositional systems in rift basins. In: Coarse-Grained Deltas. IAS Special Publication, 10, p.113-127.

HASUI, Y. 1994. Geologia estrutural das rochas da Linha 4: Avaliação e síntese dos conhecimentos. Relatório interno da Companhia do Metropolitano de São Paulo - Metrô-SP. São Paulo, 27p.

HASUI, Y. 2010. A grande colisão pré-cambriana do sudeste brasileiro e a estruturação regional. In: Geociências, 29:141-169.

HASUI, Y. \& CARNEIRO, C.D.R. 1980. Origem e evolução da Bacia de São Paulo. In: Mesa redonda: aspectos geológicos e geotécnicos da Bacia Sedimentar de São Paulo. São Paulo, 1980. Publicação Especial. São Paulo, ABGE/SBG, p. 47-52.

HASUI, Y.; CARNEIRO, C.D.R.; BISTRICH, C.A. 1978. Os granitos e granitóides da Região de Dobramentos Sudeste no Estado de São Paulo. In: Congresso Brasileiro de Geologia, 30, Anais. Recife, 25942608.

HASUI, Y.; CARNEIRO, C.D.R.; COIMBRA, A.M. 1975. The Ribeira Folded Belt. Revista Brasileira de Geociências, 5:257-266. 
HEILBRON, M.; PEDROSA-SOARES, A.C.; CAMPOS NETO, M.C.; SILVA, L.C.; TROUW, R.A.J.; JANASI, V.A. 2004. Província Mantiqueira. In: Mantesso-Neto, V.; Bartorelli, A.; Carneiro, C.D.R.; Brito Neves, B.B. (Eds.) Geologia do Continente Sul-Americano: Evolução da obra de Fernando Flávio Marques de Almeida. Beca. São Paulo, p. 203-234.

HENRIQUE-PINTO, R.; \& JANASI, V.A. 2010. Metaconglomerados e rochas associadas do Grupo São Roque a norte da cidade de São Paulo, Brasil. Revista Brasileira de Geociências, 40:409-425.

IGUSP (INSTITUTO DE GEOCIÊNCIAS DA UNIVERSIDADE DE SÃO PAULO) / SBG (SOCIEDADE BRASILEIRA DE GEOLOGIA). 1989. Workshop de Geologia da Bacia de São Paulo. Publicação especial, São Paulo, 70p.

JANASI, V.A. \& ULBRICH, H.H.G.J. 1991. Late proterozoic granitoid magmatism in the state of São Paulo, southeastern of Brazil. Precambrian Research, 51:351-374.

JULIANI, C. 1992. O embasamento pré-cambriano da Bacia de São Paulo. In: ABAS/ABGE/SBG-SP, Problemas geológicos e geotécnicos na Região Metropolitana de São Paulo. São Paulo, p.3-20.

JULIANI, C. 1993. Geologia, petrogênese e aspectos metalogenéticos dos grupos Serra do Itaberaba e São Roque nas regiões das Serras de Itaberaba e Pedra Branca, NE da cidade de São Paulo (SP). Tese de Doutoramento, Instituto de Geociências, Universidade de São Paulo, São Paulo, , 803 p.

JULIANI, C. \& BELJAVSKIS, P. 1995. Revisão da litoestratigrafia da Faixa São Roque/Serra do Itaberaba (SP). Revista do Instituto Geológico, 16:33-58

JULIANI, C.; HACKSPAKER P., DANTAS E.L., FETTER, A.H. 2000. The Mesoproterozoic volcano-sedimentary Serra do Itaberaba Group of the central Ribeira Belt, São Paulo, Brazil: implications for the age of the overlying São Roque Group. Revista Brasileira de Geociências, 30:82-86.

KLEIN, V.C. \& VALENÇA, J.G. 1984. Estruturas almofadadas em derrame ankaramítico na Bacia de São José de Itaboraí, Rio de Janeiro. In: SBG, Congresso Brasileiro de Geologia, 33, Rio de Janeiro, Anais, 9:4335:4345.

KUCHLE, J.; HOLZ, M.; BRITO, A. F.; BEDREGAL, R. P. 2005. Análise estratigráfica de bacias rifte: aplicação de conceitos genéricos das bacias de Camamu-Almada e Jequitinhonha. In: Bol. Geoc. Petrobrás, 13(2):227-244.

KUTNER, A.S. \& BJORNBERG, A.J.S. 1997. Contribuição para o conhecimento geológico-geotécnico da Bacia de São Paulo: litotipos, notação estratigráfica e feições estruturais relevantes. Revista Engenharia, 522:65-73.

LEEDER, M.R. 1995. Continental rifts and proto-oceanic rift troughs. In: Tectonics of sedimentary basins. BUSBY, C.J. \& INGERSOLL, R.V (Ed.). Blackwell Science, p. 119-148.

LEEDER, M.R. \& GAWTHORPE, R.L. 1987. Sedimentary models for extensional tilt-block/half-graben basins. Geological Society, London, Special Publications, 28:139-152.

MAWE, J. 1812. Travels in the interior of Brazil, particularly in the gold and diamond districts, by authority of Prince Regent of Portugal. London, Patternoster-Row, 368p. 
MELO, M.S.; PONÇANO, W.L.; MOOK, W.G.; AZEVEDO, A.E.G. 1987. Datações C14 em sedimentos da Grande São Paulo. In: Congresso da Associação Brasileira de Estudos do Quaternário, 1, Porto Alegre, Anais, p.427-436.

MELO, M.S.; COIMBRA, A.M.; RICCOMINI, C. 1989. Evolução dos conhecimentos sobre a geologia da Bacia de São Paulo na década de oitenta. In: Workshop de Geologia da Bacia de São Paulo. IGUSP/SBG, São Paulo, Publicação Especial, p.1-11.

MEZZALIRA, S. 1962. Novas ocorrências de vegetais fósseis cenozoicos no Estado de São Paulo. Publicação do Instituto Geográfico e Geológico, São Paulo, 15: 73-94.

MONTEIRO, M.D.; GURGUEIRA, M.D.; ROCHA, H.C. 2012. Geologia da Região Metropolitana de São Paulo. In: Twin Cities - Solos das cidades de São Paulo e Curitiba. ABMS, São Paulo, p. 15-44.

MORAES REGO, L.F. 1933. As formações cenozóicas de São Paulo. Anuário da Escola Politécnica de São Paulo, São Paulo, 2: 231-267.

PASSARELLI, C.L. 2001. Caracterização estrutural e geocronológica dos domínios tectônicos da porção sul-oriental do Estado de São Paulo. Tese de Doutoramento, Instituto de Geociências, Universidade de São Paulo, São Paulo, 254p.

PICHER, E. 1948. Regional study of soils from São Paulo - Brazil. In: Proc. Soc. Int. Conf. Soil Mech, Rotterdam, 3:222-223.

RICCOMINI, C. 1989. O Rift Continental do Sudeste do Brasil. Tese de Doutoramento, Instituto de Geociências, Universidade de São Paulo, São Paulo, 256p.

RICCOMINI C. \& COIMBRA A.M. 1992. Geologia da bacia sedimentar. In Solos da cidade de São Paulo. FERREIRA, A.A.; ALONSO, U.R.; LUZ, P.L (Ed). São Paulo, ABMS/ABEF, p.37-94.

RICCOMINI, C.; COUTINHO, J.M.V.; GUARANÁ, C.A.; COIMBRA, A.M.; HACHIRO, J.; ATENCIO, D.; IYOMASA, W.S. 1988. Evidências de hidrotermalismo em sedimentos da Bacia de São Paulo: considerações genéticas. Anais da Academia Brasileira de Ciências, 60:105-106.

RICCOMINI, C; MELO, M.S.; ALMEIDA, F.F.M.; MIOTO, J.A.; HASUI, Y. 1983. Sobre a ocorrência de um derrame de ankaramito na Bacia de Volta Redonda (RJ) e sua importância na datação das bacias tafrogênicas continentais do sudeste do Brasil. In: SBG, Simpósio Regional de Geologia do Sudeste, 4, São Paulo, Resumos, p.23-24.

RICCOMINI, C. \& RODRIGUES-FRANCISCO, B.H. 1992. Idade K-Ar do derrame de ankaramito da Bacia de Itabooraí, Rio de Janeiro, Brasil: implicações tectônicas. In: SBG, Congresso Brasileiro de Geologia, 37, São Paulo, Boletim de resumos expandidos, 2:469-470

RICCOMINI, C; SANT'ANNA, L.C.; FERRARI, A.L. 2004. Evolução Continental do Rift Continental do Sudeste do Brasil. In: MANTESSO-NETO, V.; BARTORELLI, A.; CARNEIRO, C. D. R.; NEVES, B.B.B. (orgs). Geologia do Continente Sul-Americano: Evolução da Obra de Fernando Flávio Marques de Almeida. Beca, São Paulo, p. 385-405. 
ROCHA, H.C. 1995. Algumas características dos solos arenosos terciários de São Paulo e suas implicações em obras subterrâneas. Dissertação de Mestrado. Escola de Engenharia de São Carlos, Universidade de São Paulo. São Carlos, 136p.

ROCHA, H.C. 2006. Túneis metroferroviários. In: CELESTINO, T.B.; KOSHIMA, A.; TELLES, R.C.A.; ASSIS, A. (orgs). Túneis do Brasil. CBT, DBA, p.107-183.

RODRIGUEZ, S.K. 1998. Geologia urbana da Região Metropolitana de São Paulo. Tese de Doutoramento, Instituto de Geociências, Universidade de São Paulo, São Paulo, 171p.

SADOWSKI, G.R. \& MOTIDOME, M.J. 1987. Brazilian megafaults, In: Revista Geologica de Chile, Santiago, 31:61-75.

SALVADOR, E.D. \& RICCOMINI, C. 1995. Neotectônica da região do alto estrutural de Queluz (SP-RJ, Brasil). In: Revista Brasileira de Geociências, 25:151-164.

SANT'ANNA, L.G. \& RICCOMINI, C. 2001. Cimentação hidrotermal em depósitos sedimentares paleogênicos do Rift Continental do Sudeste do Brasil: mineralogia e relações tectônicas. Revista Brasileira de Geociências, 31:231-240.

SCHOBBENHAUS, C.; CAMPOS; D.A.; DERZE, G.R.; ASMUS, H.E. 1984. Geologia do Brasil. Brasília, DNPM, $435 p$.

SERRA JUNIOR, E \& OJIMA, L.M. 1998. Caracterização e classificação de maciços rochosos. In: OLIVEIRA, A.M.S. \& BRITO, S.N.A. (orgs). Geologia de Engenharia. ABGE, São Paulo, p. 211-226.

SILVA-TELLES, P.C. 2006. Túneis antigos no Brasil. In: CELESTINO, T.B.; KOSHIMA, A.; TELLES, R.C.A.; ASSIS, A. (Ed.) Túneis do Brasil. CBT, DBA, p.20-25.

SUGUIO, K. \& TAKAHASHI, L.I. 1970. Estudo dos aluviões antigos dos rios Pinheiros e Tietê, São Paulo, SP. Anais da Academia Brasileira de Ciências, 42:555-570.

TAKIYA, H. 1991. Aplicação dos métodos quantitativos espaciais a dados geológicos da Bacia de São Paulo. Dissertação de Mestrado, Instituto de Geociências, Universidade de São Paulo, São Paulo, 109p.

TROUW, R.A.J.; HEILBRON, M.; RIBEIRO, A.; PACIULLO, F.V.P.; VALERIANO, C.M.; ALMEIDA, J.C.H.; TUPINAMBÁ, M.; ANDREIS, R.R. 2000. The central segment of the Ribeira Belt. In: CORDANI, U.G; MILANI, E.J.; THOMAZ FILHO, A. (eds). Tectonic Evolution of South America. São Paulo, p.287-310.

VAN SCHMUS, W.R.; TASSINARI, C.C.G.; CORDANI, U.G. 1986. Estudo geocronológico da parte inferior do Grupo São Roque. In: Congresso Brasileiro de Geologia, 34, Anais. Goiânia, p.1399-1406.

VARGAS, M. \& BERNARDO, G. 1945. Nota para o estudo regional do solo do centro da cidade de São Paulo. In: Revista Politécnica, n. 149, ano 41.

VARGAS, M. 1951. A carga de pré-adensamento das camadas de São Paulo. Anais da ABMS, São Paulo, v. 1 . 
VARGAS, M. 1953. Problemas de fundação de edifícios em São Paulo. Anais da ABMS, São Paulo, v. 3.

VARGAS, M. 2002. Os solos da cidade de São Paulo: histórico de pesquisas. Artigo técnico da ABGE, São Paulo, 17, 103p.

VAZ, L.F. 1996. Classificação genética dos solos e dos horizontes de alteração de rocha em regiões tropicais. In: Solos e Rochas, São Paulo, 19:117-136.

VIEIRA, S.R.S.S. 1989. Estudo lito-estrutural da região de Embu-Guaçu-Parelheiros, São Paulo. Dissertação de Mestrado, Instituto de Geociências, Universidade de São Paulo, São Paulo, 122p.

VLACH, S.R.F. 2001. Microprobe monazite constraints for an early (ca. $790 \mathrm{Ma}$ ) Brasiliano Orogeny: The Embu Terrane, Southeastern Brazil. In: III South American Symposium of Isotope Geology, Extended Abstract Volume (CD), p.265-268. 


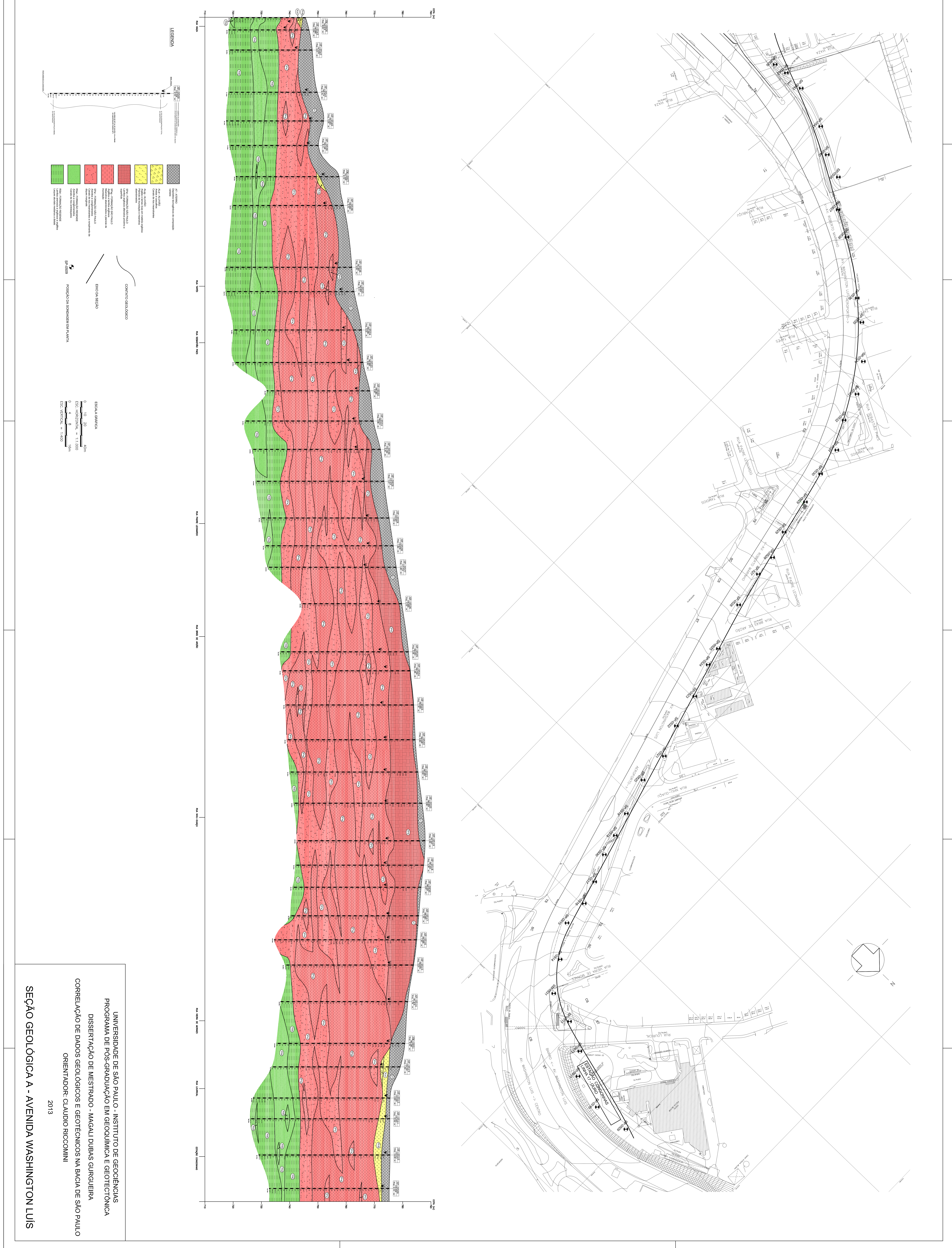




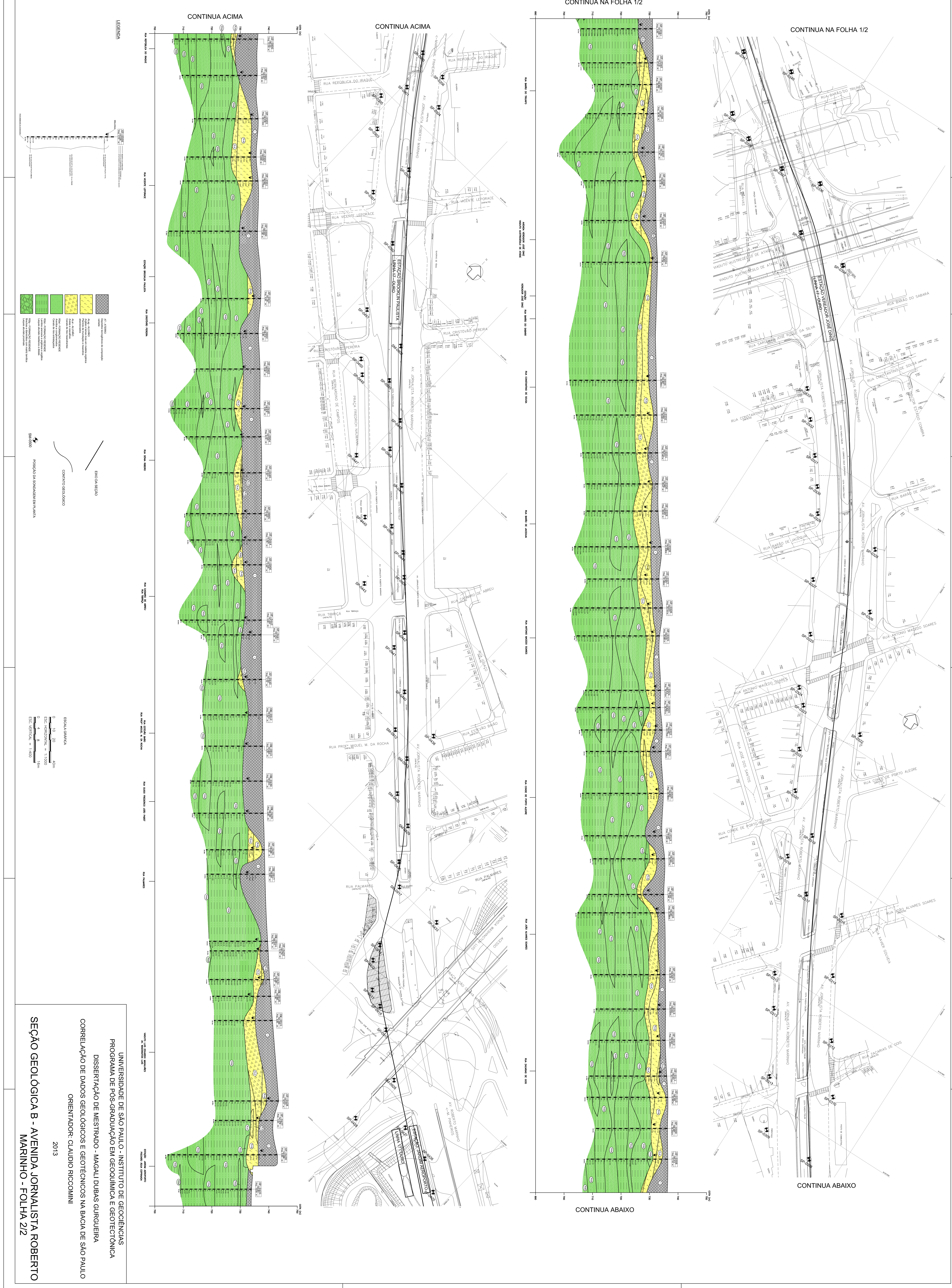


